Historic, Archive Document

Do not assume content reflects current scientific knowledge, policies, or practices. 



\section{GRISWOLD'S ANNUAL SEED CATALOG FOR 1928}

\section{WE PAY TRANSPORTATION GHARGES}

We will take care of the Postage. Express and Freight Charges on orders at Catalog prices as far as we are able to fill same but only when full remittance accompanies the order reserving the right to ship as we think best-but will endeavor to carry out purchaser's shipping requests as far as practical.

This offer to pay transportation charges give the purchaser the opportunity to get his supply of seeds from one of the oldest and most reliable seed firms in existence (business established in 1845) at reasonable prices, transportation charges paid and no charge for packages such as bags, boxes, etc. and no trouble to figure out postage. Simply follow catalog prices carefully. Enclose full remittance (and 10 cents extra if you wish goods insured) with the order and we will take care of the rest. Parcel post package cannot be traced unless insured. We shall be glad to supply your friends that require seeds with Catalogs. Mail us their addresses, please.

\section{NOVELTIES AND SPEGIALTIES}

As many of the so-called Novelties after a thorough trial prove to be of little value, we do not go extensively in to them but like to try them out as they come along and catalog some of the most worthy. Most market gardeners have their preference of varieties of seeds but for the information and suggestion to the Amateur Gardener or person not familiar with the different varieties we have checked thus $(\star)$ some of the more popular and newer sorts of vegetable seeds through the Catalog. This does not mean that the varieties not checked are not worthy but simply to give some idea of the more popular varieties and perhaps help in making a selection.

TERMS. Prices in this catalog are net cash on orders amounting to $\$ 15.00$ or less.

To market gardeners and others who purchase considerable quantities of seeds we allow the following discounts from Catalog prices when full remittance accompanies the order: On orders of $\$ 15.00$ to $\$ 25.00,5$ percent, orders amounting to more than $\$ 25.00$, 10 percent. This discount applies to club orders also. If your order is small make up a club order with your neighbors and take advantage of the above discount. Catalogs furnished if wanted.

REMITTANCES. Remittances should be made by Post-Office or Express money order, registered mail or bank draft. Parties with established credit may send personal checks. Postage stamps accepted for amounts under $\$ 1.00$. Make Post Office money orders payable to Thos. Griswold \& Co. at South Wethersfield, Conn.

NON-WARRANTY. We take great care to supply only such seeds as are strong in vitality and true to type, and will, we think, with proper culture, yield satisfactory results; but as most of the failures with seeds are due to causes entirely beyond our control, such as careless handling after leaving our hands, too deep or too shallow planting and unfavorable weather or soil conditions, etc. we give no warranty, express or implied, as to description, quality, productiveness or any other matter of any seeds, plants or bulbs we send out, and will not be in any way responsible for the crop. If the purchaser does not accept the goods on these terms, they are at once to be returned, Thos. Griswold \& Co.

Our office and warehouse are located about six miles south of Hartford and are reached by the line of the Hartford and Middletown trolley (Station 23). 


\section{ORDER SHEET}

THOS. GRISWOLD \& CO.

South Wethersfield, Conn $192 \ldots$

Gentlemen:

Please send the following goods as soon as possible, prefer shipment by................ If you pay transportation charges, use own judgment in shipping. Parcel Past, Exprese or Freight

Name

P. O. Box

Post Office Address

Street Address......................

County

(R. F. D. Route No.

R. F. D. Box (...)

If shipped by Express send to

$$
\text { Name of Perroon }
$$

.......

..........

If shipped by Freight send to

Name o.............

T...........

Stat

State

Often Express \& Freight Stations are different address than Post Office. Please fill out above.

Please write plainly to avoid mistakes and keep copy of order for reference.

EF- In eommon with other reliable Seedsmen, we sell our goods eubject to dibclaimer an adopted by the American Seed Trado Associstion, as follows: Thos. Grissold \& Co. give no warranty. express or implied. us to deseription. quality. productiveness or any other mattes of any geeds. bulbs. of plants we send out and we will not be in any way responsible for the crop. If the purehaser does not accept the goods on these terms, they are at once to be seturned.
Amount of Order

(is any. See ineide cov.)

(it any. Sansh discount

Insurance

Enclosed please find

P. O. Money Order

Express Money Order $\$$

Check or Draft

Postage Stamps

Caah

.........

$\$ \ldots \ldots \ldots$

$\$ \ldots . . .6$

If goods are to be insured enclose 10 cents extra for insurance.

NOTE-We atand postage or trans. portation charges on orders at catalog prices but only when full remittance accompanies the order re serving the right to ship as we think best. If for any reason we are unable to fill order in part or in full money will be refunded.

Thos. Griswold \& Co.

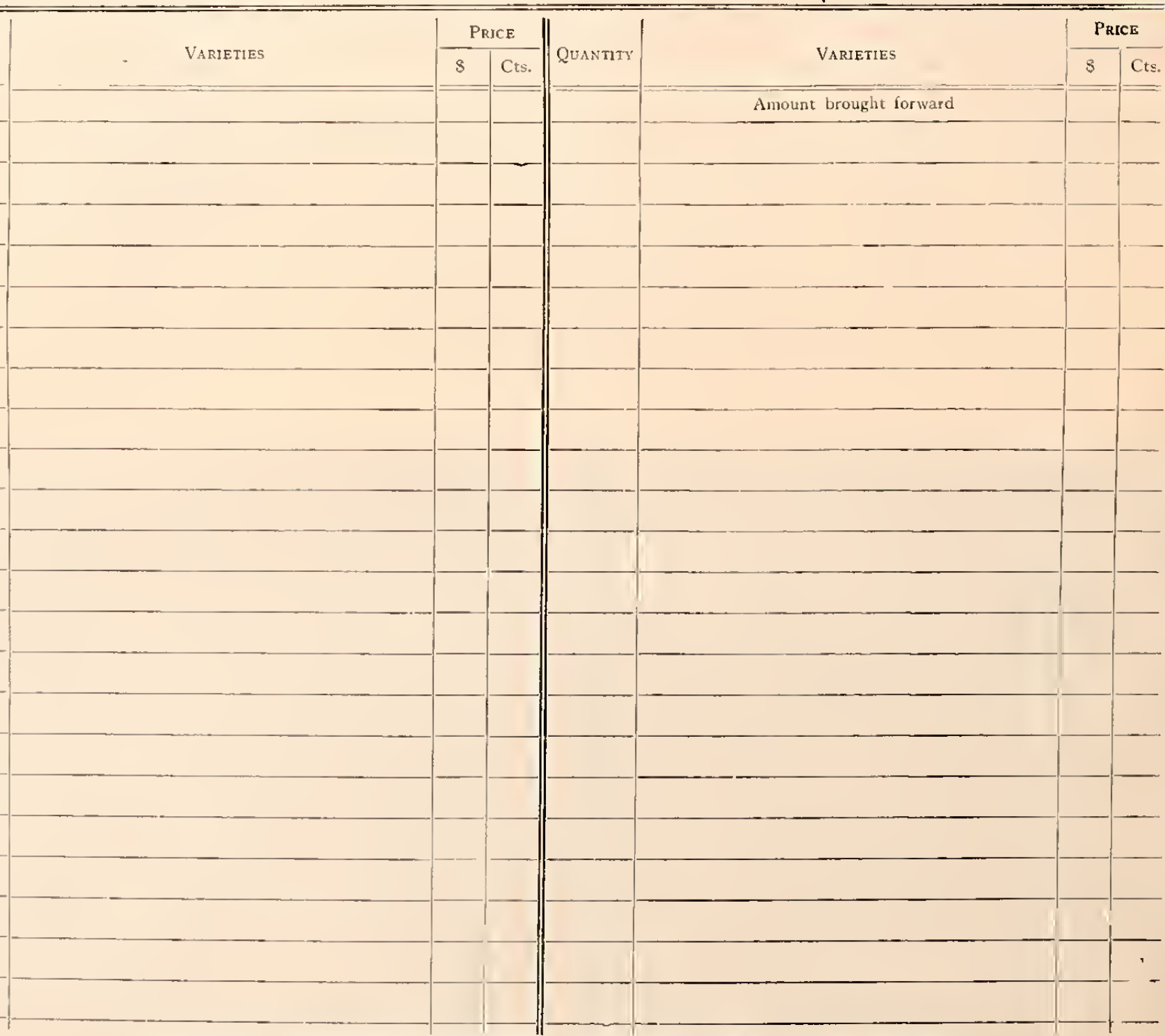





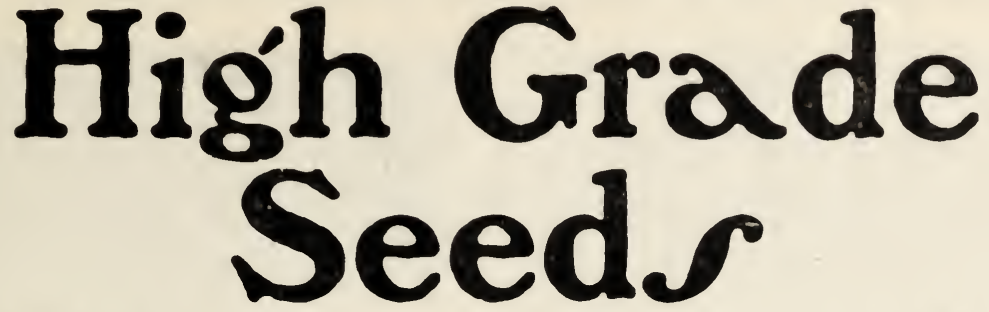

\section{VEGETABLE FLOWER FIELD}

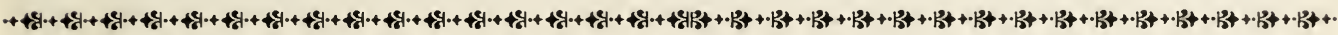

\section{SPARAGIO ASPARAGUS SZPARAGI}

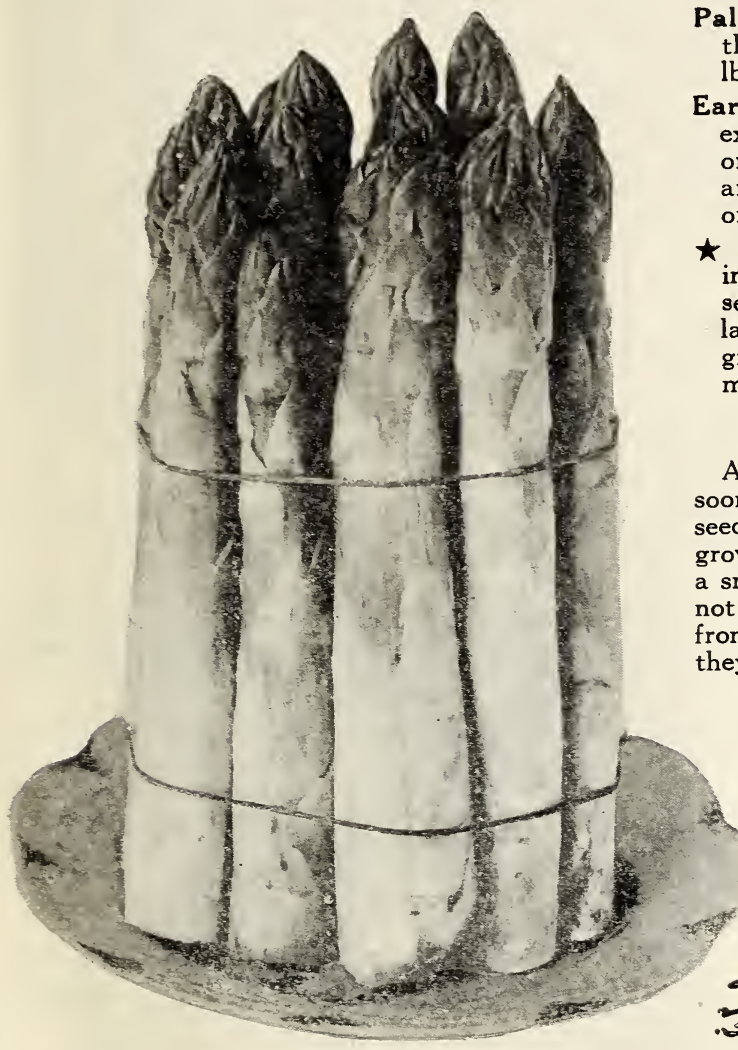

Palmetto. A prolific and continuous yielder of thick shoots of delicious flavor. Oz. $10 \dot{k}, 1 / 4$ lb. 20 c, lb. 65 \&, 5 lbs. or more, per lb. 60 c.

Early Giant Argenteuil. Of French origin and extensively cultivated by many growers and one of the finest to grow. Stalks large, succulent and tender. Oz. 10 c, $1 / 4 \mathrm{lb} .25$, lb. 75 c, $5 \mathrm{lbs}$ or more, per lb. 70 ć.

$\star$ Mary Washington. The best of the Washington type of Asparagus developed by careful selection by Dr. J. B. Norton. An early large rust resisting variety and very vigorous grower. Oz. 15 c, $1 / 4$ lb. 45 c, lb. $\$ 1.50,5$ lbs. or more, per lb. $\$ 1.40$.

\section{Asparagus Roots}

Asparagus cuttings can be obtained 1 to 2 years sooner by setting the roots than by sowing the seed. One year old roots are generally set by large growers as they are much easier handled but for a small bed two year old roots are preferable. Do not begin cutting the shoots for at least one year from setting so that the roots will get a good hold, they will grow much larger shoots.

\section{Asparagus Seed}

Culture - Before sowing Asparagus seed should be well soaked in warm water. Sow in April or May, in good soil, in drills 12 to 14 inches apart and about 2 inches deep. When the roots are one or two years old transfer them to a permanent bed in rows 3 to 4 feet apart, and afterward cultivate freely. Leave 15 to 18 inches between the roots in the row. The bed should be enriched with well-rotted manure and thoroughly worked over to a depth of nearly 1 foot. A liberal dressing of coarse manure should be applied each Fall, and in the Spring forked in. An ounce of seed will sow 75 to 100 feet of drill and produce about 400 roots.

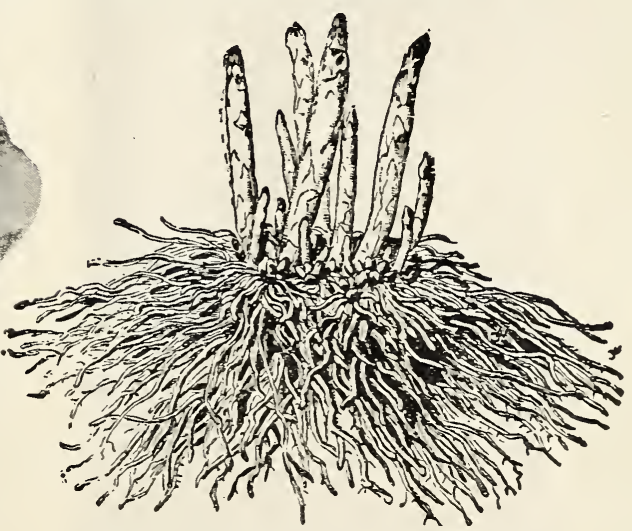

Mary Washington Roots

One year old roots $50, \$ 1.00 ; 100, \$ 1.75 ; 500$, $\$ 7.00 ; 1000, \$ 11.00 ; 2000$ or more, per $1000, \$ 10.00$.

Two year old roots, $50, \$ 1.25 ; 100, \$ 2.00 ; 500$, $\$ 7.50 ; 1000, \$ 12.00 ; 2000$ or more, per $1000, \$ 11.00$. Write for prices on large quantities and state quantity wanted. 


\section{fagiuoli BEANS fasola}

\section{Half Bushel at Bushel Rate}

Culture - As Beans are exceedingly tender it is useless to plant them until the ground is warm and dry. They succeed best in sandy loam, fertilized with well-rotted manure. Plant in drills 2 inches deep and 2 feet apart, or in hills 2 feet apart each way. Place the beans 2 or 3 inches apart in the drills. Frequent but shallow cultivation should be given, but never disturb the vines when wet. For a succession throughout the season sow every two weeks until early September. One quart will plant 100 feet of drill; one bushel to the acre.

Pole or Running varieties need more room and should be planted in hills about $31 / 2$ feet a part each way. The Limas are even more tender than other varieties and should not be planted before warm weather sets in. One quart will plant 75 hills.

\section{Dwarf Green-Podded Varieties}

$\downarrow$ Bountiful or Improved Yellow Six Weeks. A rich, green, flat podded Bean, finest quality. Pods large, broad, stringless, fleshy and tender. A great cropper. Pt. $35 \phi$, qt. $60 \phi, 4$ qts. $\$ 1.90$, pk. $\$ 3.25$, bus. $\$ 12.00$.

Extra Early Refugee. A light green-podded Bean

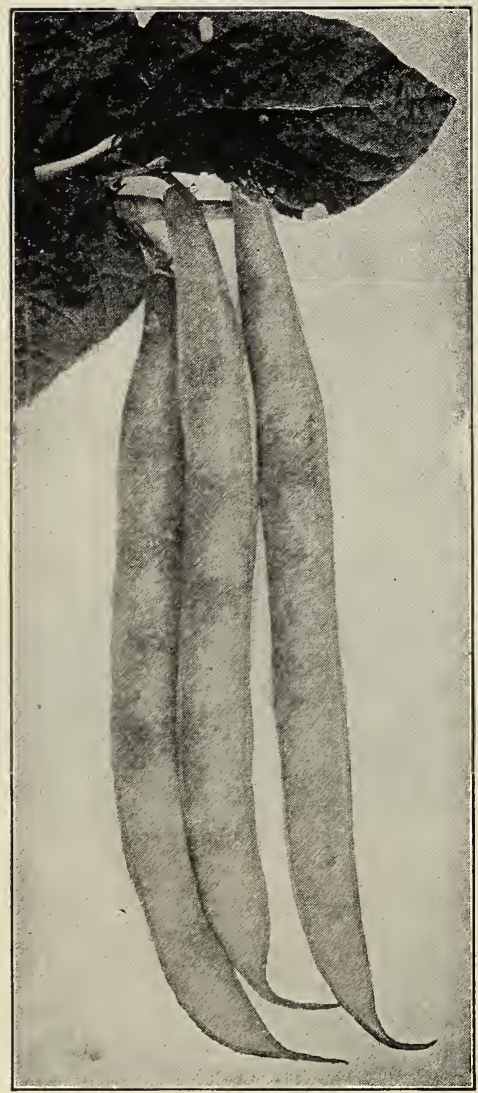

Stringless Green Pod

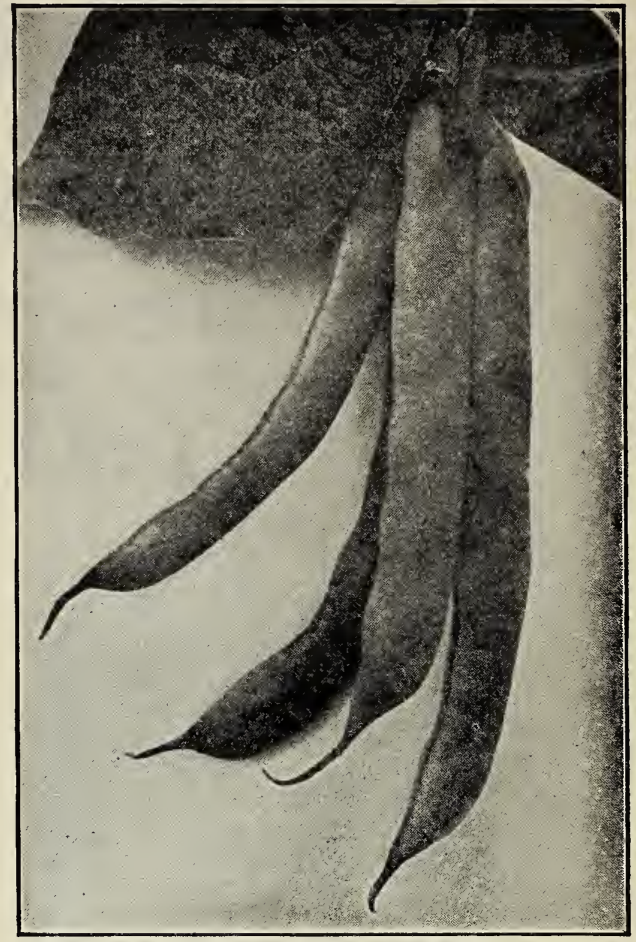

Bountiful or Improved Yellow Six Weeks

of fine quality, maturing earlier than most varieties. Pods are long, round and tender. A desirable variety for market or home use. $\mathrm{Pt}$. $35 \phi$, qt. $60 \phi, 4$ qts. $\$ 1.90$, pk. $\$ 3.25$, bus. $\$ 12.00$.

$\star$ Full Measure. A fine stringless high quality bean, little later than Burpee's Stringless. Vine vigorous and bears abundantly, medium, green, long, round, fleshy pods. $\mathrm{Pt}$. $35 \%$, qt. $60 \%, 4$ qts. $\$ 1.90$, pk. $\$ 3.25$, bus. $\$ 12.00$.

Ruby Dwarf Horticultural. Improved strain of Dwarf Horticultural. Early, vigorous and very productive. Pods round, straight and stringless; about five inches long, greenish yellow color splashed with carmine; very attractive. This variety is extensively used when young for a string bean and the dry beans for baking and soups. Pt. $35 \phi$, qt. $60 \%, 4$ qts. $\$ 1.90$, pk. $\$ 3.25$, bus. $\$ 12.00$.

Large White Marrow. A heavy yielder and good as a shelled bean either green or ripe. Popular for Winter use as a shelled or dry bean. Pt. $25 \phi$. qt. 40 \&. 4 qts. $\$ 1.40$, pk. $\$ 2.60$, bus. $\$ 10.00$.

$\star$ Stringless Green Pod (Burpee's). This Bean is probably more generally planted than any other green podded variety being highly prized for its hardiness and abundance of yield. The pale, long, round, green pods are stringless, crisp, meaty and tender. Pt. $35 \%$, qt. $60 \%, 4$ qts. $\$ 1.90$, pk. $\$ 3.25$, bus. $\$ 12.00$.

Red Kidney. A very desirable cooking bean. The ripe dried beans are red color and kidney shaped. A very nice shell bean for baking and soups. Pt. $25 \phi$, qt. $40 \notin, 4$ qts. $\$ 1.40$, pk. $\$ 2.60$, bus. $\$ 10.00$.

Yellow Eyed Field Beans. A very popular shell variety for either baking or soups. $\mathrm{Pt}$. $25 \phi$, qt. $40 \notin, 4$ qts. $\$ 1.40$, pk. $\$ 2.60$, bus. $\$ 10.00$. 


\section{Wax, or Butter Varieties}

$\star$ Pencil Pod Black Wax. Hardy and prolific. The rich, light yellow. pencil-like pods are very brittle and tender. Altogether an exceedingly fine strain and popular among gardeners. Pt. 35 c. qt. 60 c, 4 qts. $\$ 1.90$, pk. $\$ 3.25$, bus. $\$ 12.00$.

Improved Golden Wax. An improved strain of Golden Wax and well worthy of cultivation. The pods grow straight and flat and are of a golden yellow color. Pt. 35c. qt. 60 c. 4 qts. $\$ 1.90$. pk. $\$ 3.25$, bus. $\$ 12.00$.

Prolific Black Wax. A decided improvement on the old Black Wax. The waxy yellow pods are round, full, stringless and tender. $\mathrm{Pt} .35 \mathrm{c}$, qt. 60 ć, 4 qts. $\$ 1.90$, pk. $\$ 3.25$, bus. $\$ 12.00$.

$\star$ Round Pod Kidney Wax. A fine early round podded stringless variety of highest quality. Pods 5 to 6 inches long, somewhat curved, bright yellow, waxy color. $\mathrm{Pt}$. 35c, qt. 60 c, 4 qts. $\$ 2.00$, pk. $\$ 3.50$, bus. $\$ 13.00$.

Unrivaled Wax. A very early, productive and showy variety. The clear yellow pods are nearly straight, little flattened, about 5 inches long and practically stringless. Good quality. Pt. 35k, qt. 60 k, 4 qts. $\$ 2.00$, pk. $\$ 3.50$, bus. $\$ 13.00$.

Wardwell's Kidney Wax. One of the most popular of the old standard early varieties, producing a heavy crop of large, flat, yellow pods, which are not liable to rust. $\mathrm{Pt}$. $35 \mathrm{c}$, qt. $60 \mathrm{k}$, 4 qts. $\$ 1.90$, pk. $\$ 3.25$, bus. $\$ 12.00$.

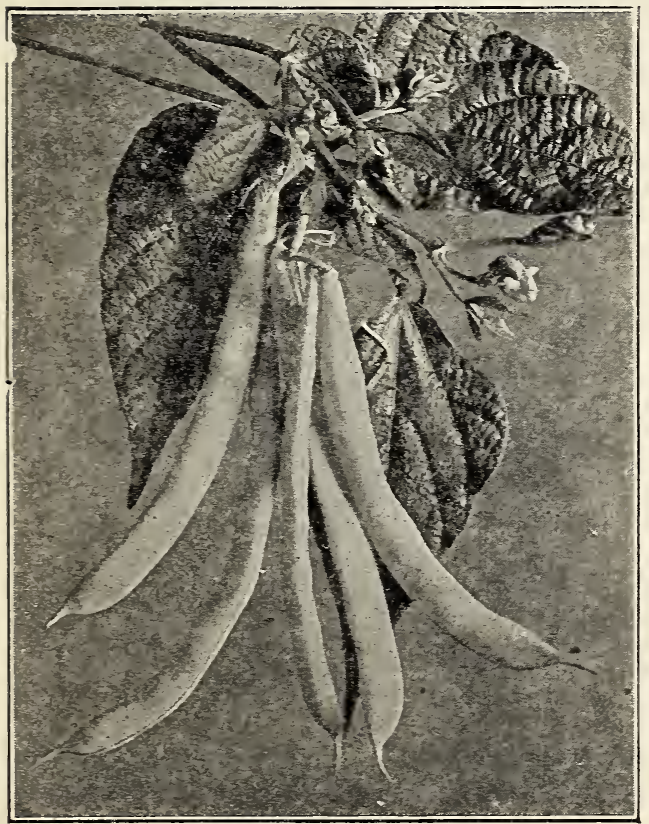

Round Pod Kidney Wax

\section{Dwarf, or Bush Lima Varieties}

$\star$ Burpee's Improved Bush Lima. Comparing their particular merits, this Improved Bush Lima is declared to be much superior to the original Burpee's Bush Lima. The dwarf vine is of more vigorous growth, matures earlier, and the large, plump beans are of better flavor. Pt. 40 ć, qt. 65 c, 4 qts. $\$ 2.25$, pk. $\$ 4.00$, bus. $\$ 15.00$.

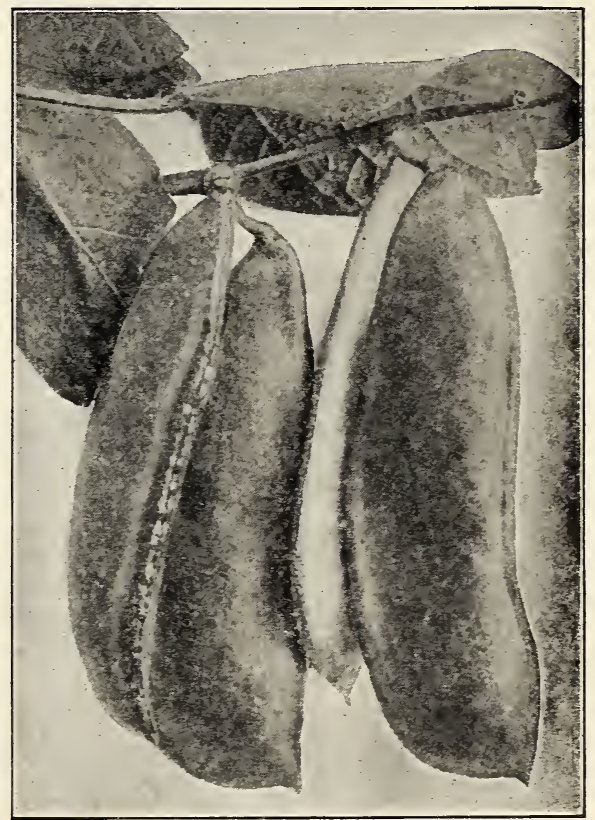

Burpee's Improved Bush Lima

Some of the more popular and newer varieties are checked thus $(\star)$. See inside front cover. 


\section{BEANS-Continued}

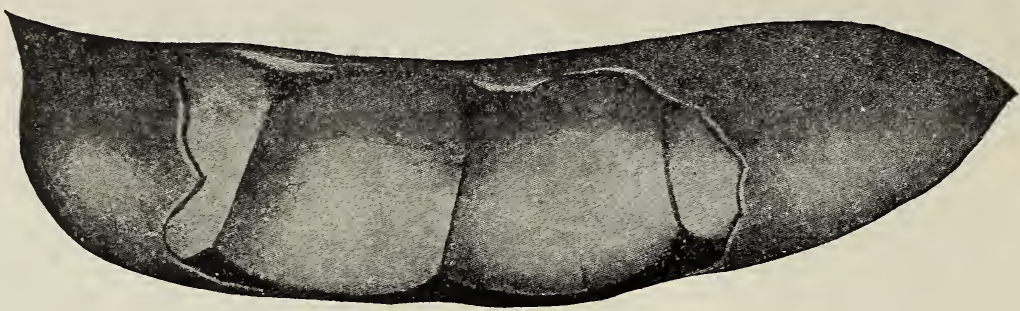

Early Giant Bush Lima

Early Giant Bush Lima. In our trial of this variety and comparing it with Burpee's Improved Bush Lima we found it similar in growth of vine, somewhat earlier and larger podded. An excellent type and we feel sure it will prove very satisfactory to those that try it. $\mathrm{Pt}$. $45 \phi$, qt. $70 \phi$, 4 qts. $\$ 2.40$, pk. $\$ 4.25$, bus. $\$ 16.00$.

$\star$ Fordhook Bush Lima. A Bean of exceptional merit, resembling Dreer's Bush Lima in many respects, but a distinct improvement. Pods are larger, more uniform, and filled with extra large beans of fine quality. Early and very prolific. Pt. $40 \phi$, qt. $65 \xi, 4$ qts $\$ 2.25$, pk. $\$ 4.00$, bus. $\$ 15.00$.

Henderson's Bush Lima. A plant of low, bushy growth, very early, and yielding a profuse and continuous crop of small beans of superb table quality. Pt. $35 \xi$, qt. $60 \xi, 4$ qts. $\$ 1.90$, pk. $\$ 3.25$, bus. $\$ 12.00$.

\section{Pole, or Running Varieties}

Early Jersey Lima. One of the earliest of Pole Limas; a vigorous, healthy grower and a fine bearer. Pt. $35 \xi$, qt. $60 \notin, 4$ qts. $\$ 2.00$, pk. $\$ 3.75$, bus. $\$ 14.00$.

$\star$ Early Leviathan Lima. A productive early large variety, about week earlier than any other large pole Lima. Pods long and large, containing 5 or 6 large beans. Pt. $35 \dot{k}$, qt. $60 \xi, 4$ qts. $\$ 2.00$, pk. $\$ 3.75$, bus. $\$ 14.00$.

$\star \quad$ King of the Garden Lima. Yields an abundance of pods, 5 to 6 inches long and filled with large beans, which, when cooked, are tender and delicious. Pt. 35 , qt. 60 \&, 4 qts. $\$ 2.00$, pk. $\$ 3.75$, bus. $\$ 14.00$.

Horticultural, or Cranberry Pole. An old favorite variety. Long, green pods, red speckled. Pt. 35 , qt. $55 \phi, 4$ qts. $\$ 1.75$, pk. $\$ 3.00$, bus. $\$ 11.00$.

$\star$ Kentucky Wonder (Old Homestead) Stringless. Early and enormously productive, the long, bright green pods growing in clusters. Stringless, and of the best flavor. Pt. $35 \phi$, qt. $55 \phi$, 4 qts. $\$ 1.75$, pk. $\$ 3.00$, bus. $\$ 11.00$.

SOY BEANS - See Page 38.

\section{BARBABIETOLA \\ BEETS \\ BURAKI}

Culture - Beets are of easy culture and one of the most useful and profitable crops grown. For early table use sow as early in Spring as the ground can be worked, in drills 16 to 20 inches apart, and for a succession at intervals of two weeks until the first week in July. About the middle of May is the time to sow for general crop. They succeed best in a firm light soil well enriched.

The tops of Beet plants form a very desirable table vegetable, when cooked and served in the same manner as greens. Sow the seeds $1 / 2$ to 1 inch deep, and thin the young plants to 4 to 6 inches apart. One ounce of seed will sow 50 feet of drill; 5 or 6 pounds to the acre.

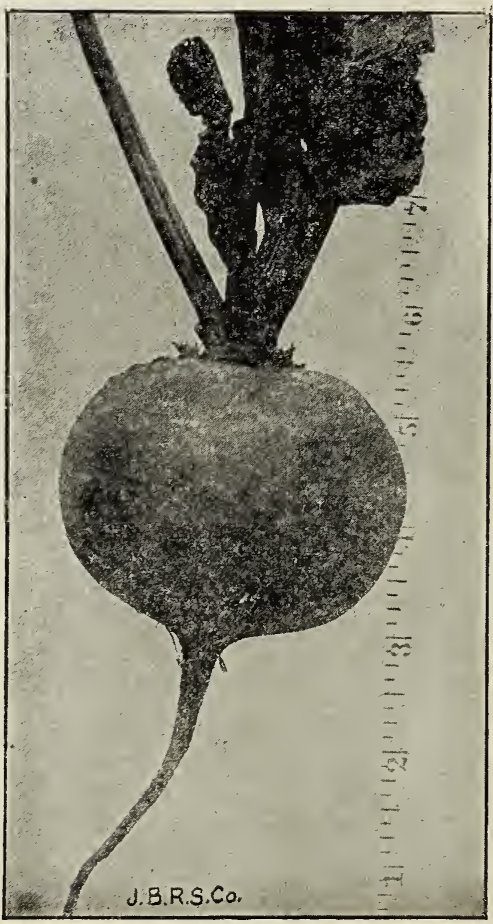

Early Wonder 


\section{Garden Varieties}

Columbia (Burpee's). Round with smooth skin; dark red flesh; sweet and tender. Oz. $15 \mathrm{c}, 1 / 4 \mathrm{lb}$. 35 c, lb. $\$ 1.00,5$ lbs. or more, per lb. 90 c.

^ Crosby's Egyptian Turnip. An improved strain of the old Egyptian and an excellent firstearly sort, uniform in shape and of a dark blood color. One of the most popular garden varieties. Oz. 15 c, $1 / 4$ lb. 35 c, lb. $\$ 1.00,5$ lbs. or more, per lb. 90 c.

* Early Wonder. A fine type of Crosby's Egyptian, little more globe shaped, dark red roots, with small top. Oz. 15 c, $1 / 4$ lb. 35 c, lb. $\$ 1.00$, 5 lbs. or more, per lb. 90 ć.

* Detroit Dark Red. One of the finest strains in cultivation and good for early or late sowing. Deep red and very tender. A grand keeper. Oz. 15 c, $1 / 4 \mathrm{lb}$. 35 c, lb. $\$ 1.00,5 \mathrm{lbs}$. or more, per lb. 90 c.

Early Crimson Globe. An early globe-shaped variety; flesh rich, crimson, and of splendid quality. Oz. $15 \mathrm{c}, 1 / 4 \mathrm{lb} .35 \mathrm{c}, \mathrm{lb} . \$ 1.00,5 \mathrm{lbs}$. or more, per lb. $90 \mathrm{c}$.

Early Eclipse. A medium-sized, round, bright red Beet of fine quality. Desirable for home or market garden. Oz. $10 \hat{k}, 1 / 4 \mathrm{lb} .30 \dot{c}, 1 \mathrm{~b} .90 \dot{c}$, 5 lbs. or more, per lb. 80 c.

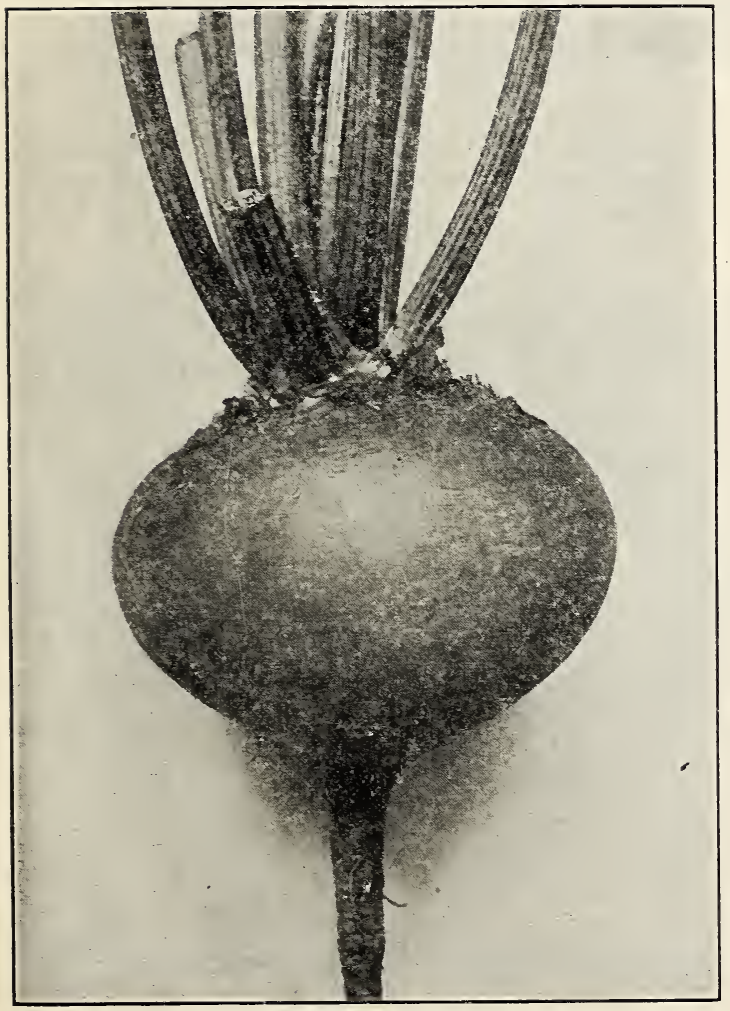

Crosby's Egyptian

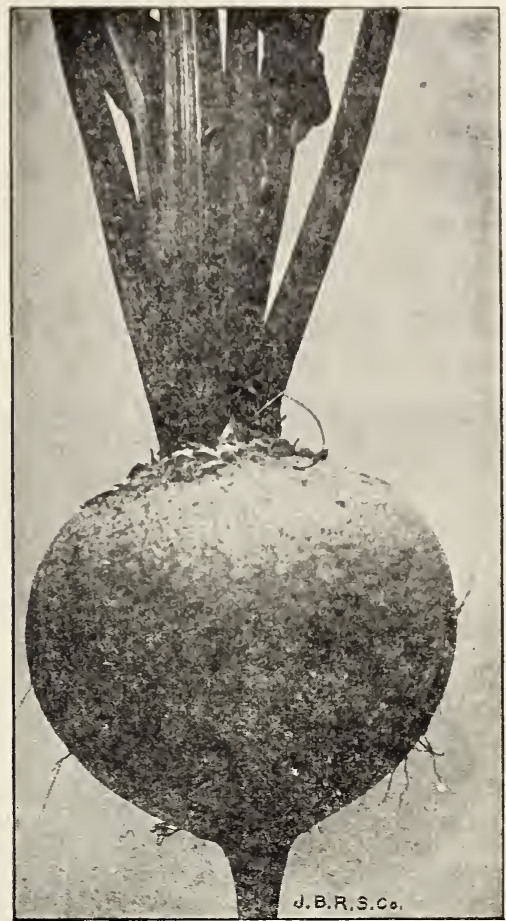

Detroit Dark Red

Improved Early Blood Turnip. A distinct improvement on the original type; fine stock, succulent and sweet. Oz. $10 \xi, 1 / 4 \mathrm{lb} .30 k, \mathrm{lb}$. $90 \notin, 5$ lbs. or more, per lb. 80 ф.

\section{MANGEL BEETS}

For Stock Feeding

Culture - In order to grow well, Mangels require a deep soil and plenty of manure. Sow in May or June in rows 2 feet apart, and thin to 6 inches in the rows. One ounce of seed will sow 50 feet of drill; 6 to 8 pounds to the acre.

Giant Half Sugar. A variety highly recommended for stock feeding. Of large size; bright pink color, shading to white. Oz. $10 \xi, 1 / 4 \mathrm{lb} .20 \xi$, lb. 45 ć, 5 lbs. or more, per lb. $40 \dot{\phi}$.

Golden Tankard. A medium sized, globe shaped beet golden yellow color of good quality and a fair yielder. Oz. 10 c, $1 / 4$ lb. 20 c, lb. 45 k, 5 lbs. or more, per lb. 40 c.

^ Mammoth Long Red Mangel. A great producer, attaining an enormous size. Oz. $10 k$, $1 / 4$ lb. 20 , lb. 45 k, 5 lbs. or more, per lb. 40 . 


\section{BRUSSELS SPROUTS}

Culture - An estimable species of the Cabbage family. It produces small heads or sprouts all along the stalk, which, cooked in the same way as Cauliflower, are a great delicacy. For Fall use sow in the seedbed in early Spring and in June for late crop. Set the young plants in rows about 2 feet apart and 18 inches to 2 feet apart in the rows. The flavor is improved by early frosts. One ounce will produce about 2,000 plants.

Long Island Strain. Compact heads of delicious flavor and extremely popular. $1 / 2$ oz. $10 \phi$, oz. $15 \phi, 1 / 4$ lb. $45 \phi$, lb. $\$ 1.50$.

\section{cavolo cappucto GABBAGE KapUsta}

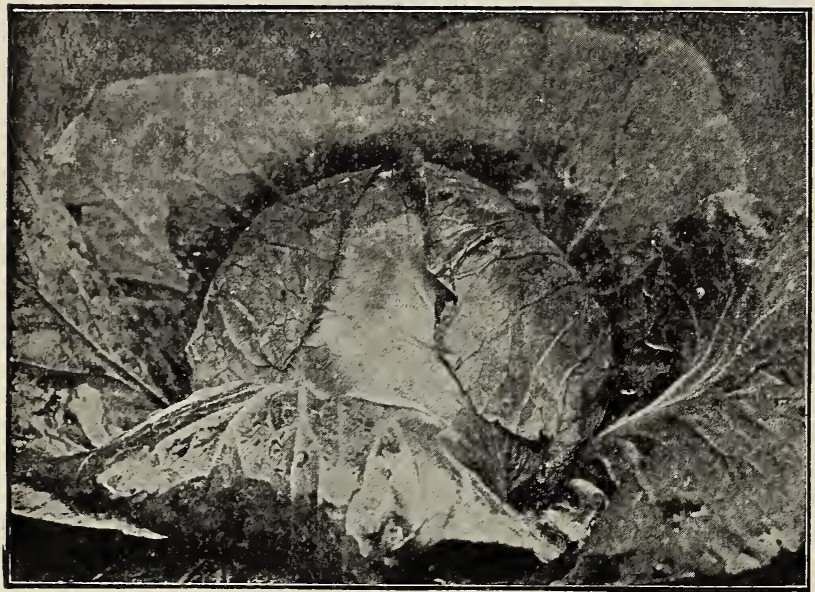

Autumn King, or World Beater

Culture - Cabbage succeeds best in rich, well-drained, deep, loamy soil. For Early Cabbages sow seeds of the earliest kinds in hotbeds in February or beginning of March and transfer the young plants to coldframes, where they will harden preparatory to setting out in the open ground. As soon as the garden soil can be worked, transplant in rows 2 feet apart and at intervals of 18 or 20 inches in the rows. For late or Winter use sow in beds or drills in the open ground in June or July, thin to secure healthy, stocky growth, and transplant when ready. One ounce will produce 2,000 to 3,000 plants. $1 / 2 \mathrm{lb}$. seed will produce plants enough for an acre.

Autumn King, or World Beater. One of the finest of Winter Cabbages, prized for its enormous solid heads of superior quality. Valuable for Winter storing. $1 / 2$ oz. $20 \phi$, oz. $30 \notin, 1 / 4$ lb. $85 \phi$, lb. $\$ 2.75$.

$\star$ Copenhagen Market. A fine early varietyof Danish origin nearly as early as Jersey Wakefield. Heads large, round

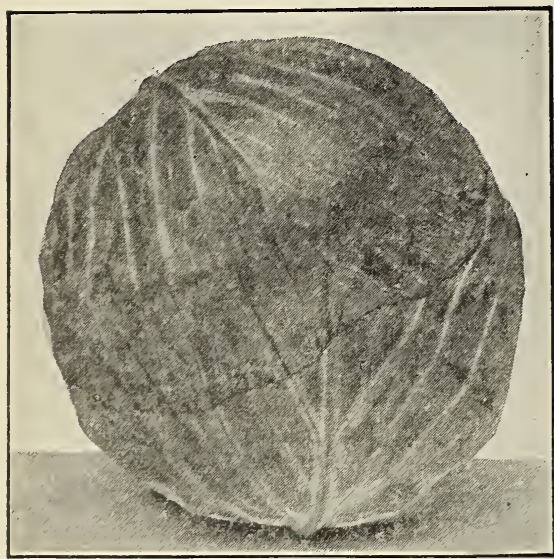

Danish Ball-Head

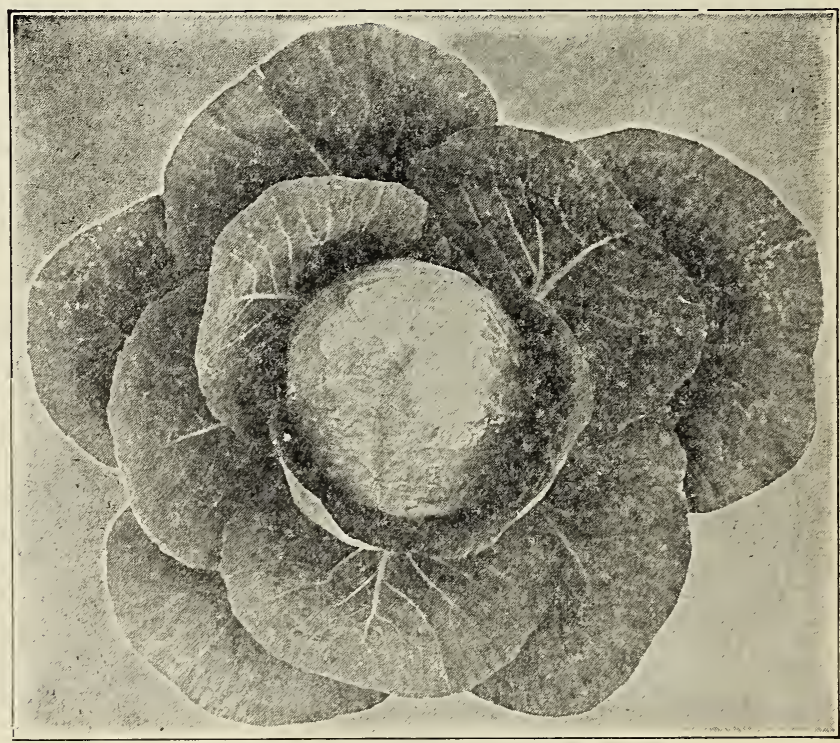

Copenhagen Market 
Danish Ball-Head. (Short Stem.) Unrivaled as a Winter keeper, its solid heads being exceedingly crisp and tender. $1 / 2$ oz. $20 \mathrm{k}$, oz. $30 \mathrm{k}, 1 / 4 \mathrm{lb}$. 85 c, lb. $\$ 2.75$.

* Early Jersey Wakefield. This first early variety is extremely popular for an extra early cabbage. The heads are of medium size, conical in form and of unsurpassed quality. $1 / 2 \mathrm{oz}$. 20 c, oz. 35 c, $1 / 4$ lb. $\$ 1.00$, lb. $\$ 3.50$.

Early Spring. Planters of extra-early Cabbages will find this a wonderfully profitable variety. Its heads are large and very solid and as it produces few outer leaves can be set very close, thus increasing the tonnage per acre. $1 / 2$ oz. 20 , oz. 30 k, $1 / 4$ lb. 85 , lb. $\$ 2.75$.

Early Winnigstadt. One of the best known second-earlies and everywhere popular. The small, pointed heads, tightly folded, are greatly valued for general use. A sure header and a splendid keeper. $1 / 2$ oz. $20 \xi$, oz. $30 \xi, 1 / 4$ lb. $80 \phi$. lb. $\$ 2.50$.

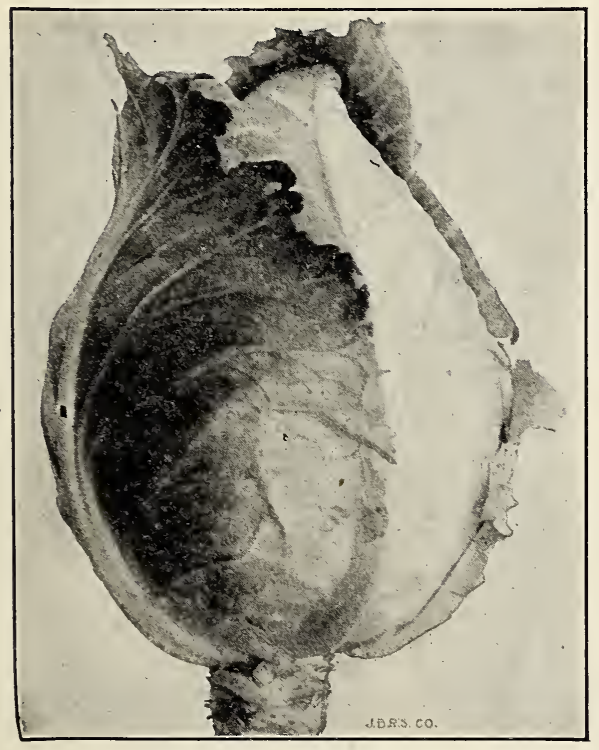

Early Jersey Wakefield

Golden Acre. An extra early type of Copenhagen said to mature week earlier, which makes it a very valuable market variety. Heads are large, firm and very uniform. Market gardeners are making money with this Cabbage by getting it in market early. $1 / 2$ oz. 25 , oz. 45 \&, $1 / 4$ lb. $\$ 1.75$. lb. $\$ 6.00$.

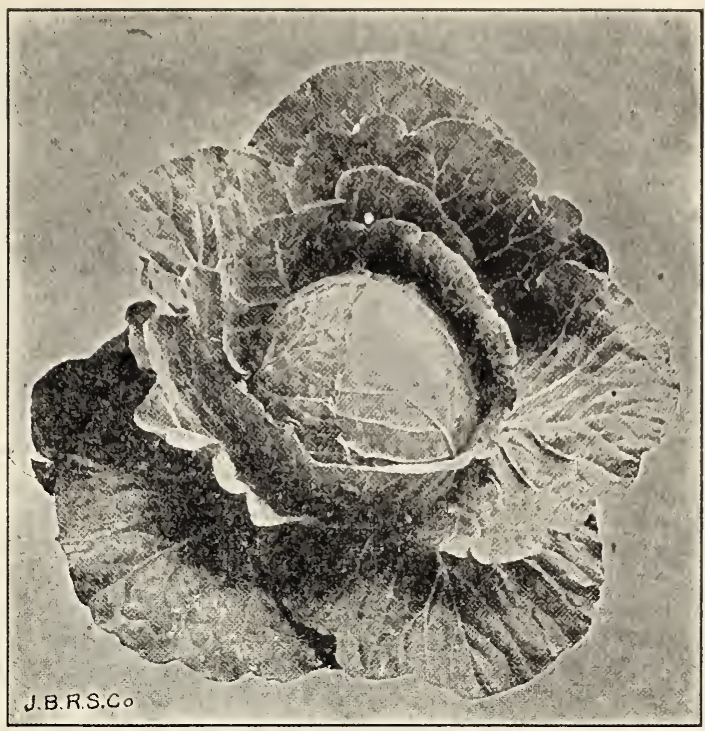

Golden Acre

Large Jersey Wakefield, or Charleston. Matures early and has practically all the favorable points of the Early Jersey Wakefield, but is larger. Very desirable for the market gardener. $1 / 2$ oz. 20 , oz. 35 \&, $1 / 4$ lb. $\$ 1.00$, lb. $\$ 3.50$.

Perfection Drumhead Savoy. Dark green wrinkled leaves: heads large, crisp and tender.

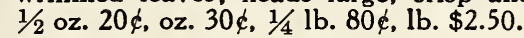

* Premium Late Flat Dutch. An old and popular variety for Autumn and Winter use. $1 / 2$ oz. $20 \xi$, oz. $30 \xi, 1 / 4 \mathrm{lb}$. $85 \dot{\xi}, \mathrm{lb}$. $\$ 2.75$.

Surehead. As its name implies, a sure header, and a variety which gives satisfaction wherever grown. Heads are large, uniform and very hard and firm. $1 / 2$ oz. 20 , oz. $30 \xi, 1 / 4$ lb. 85 , lb. $\$ 2.75$.

\section{RED CABBAGE}

Mammoth Red Rock. A deep red pickling Cabbage; extremely solid heads. $1 / 2$ oz. $20 \xi$, oz. $35 \xi$. $1 / 4$ lb. $90 \%$, lb. $\$ 3.00$.

Red Dutch Pickling. Fine for pickling and Winter use. Medium-sized heads, very solid and of splendid flavor. $1 / 2$ oz. $20 \xi$, oz. $35 \xi, 1 / 4 \mathrm{lb}$. $90 \&$, lb. $\$ 3.00$.

\section{BIETA $S W I S S C H A R D$ Spinach Beet}

This delicious vegetable should occupy a plot in every home garden. It is cultivated for its tender leaves, which are used as Spinach, the midrib being often cooked and prepared the same as Asparagus. The roots are unfit for use. It is productive throughout the season - a veritable "Cut-and Come-Again." Cultivate same as Beet.

Dark Green. Leaves of this variety are dark green with lighter colored stem. Makes excellent greens also extensively grown for chicken feed. $\mathrm{O} z .10 \%$. $1 / 4$ lb. 25 . lb. 60 \&. 5 lbs. or more, per, lb. 50 . 
$\star$ Lucullus. A very attractive and choice variety. The cream colored leaf stems are long and broad and thicker than the ordinary variety. The leaves are light bright green in color and distinctly crumpled. Oz. $10 \AA, 1 / 4 \mathrm{lb} .30 \AA, \mathrm{lb} .80 \AA$. 5 lbs. or more, per lb. $70 \phi$.

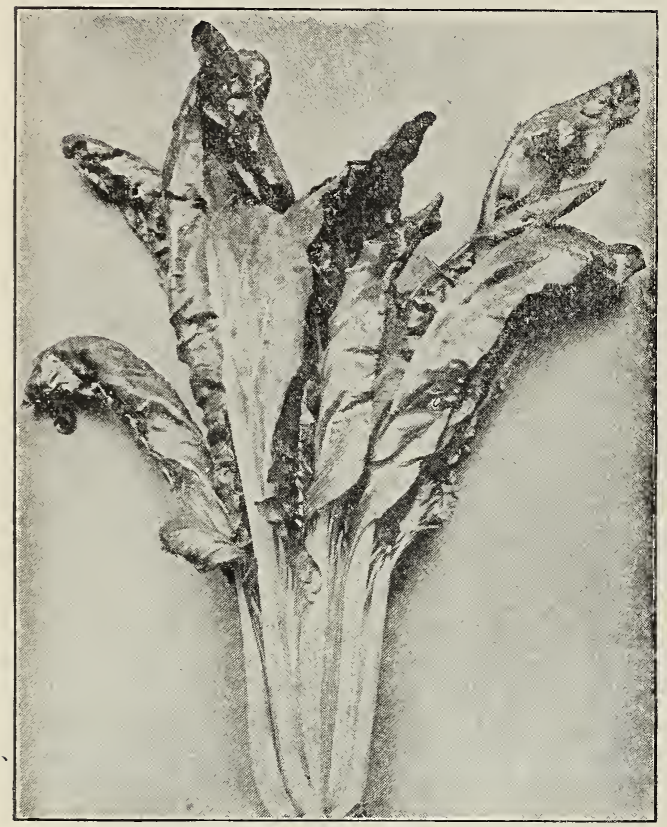

Lucullus Swiss Chard

\section{i carota GARROTS marchew}

Culture - The Carrot is an easily grown vegetable, but gives most satisfactory results in a well-manured, sandy loam, thoroughly worked. May be sown for succession from early Spring to Midsummer. Sow seed in drills 15 to 18 inches apart and cover lightly. Press the soil firmly over the seed, especially in dry weather. Thin to 3 to 4 inches apart in the rows. One ounce of seed will sow 100 feet of drill; 3 to 4 pounds to an acre.

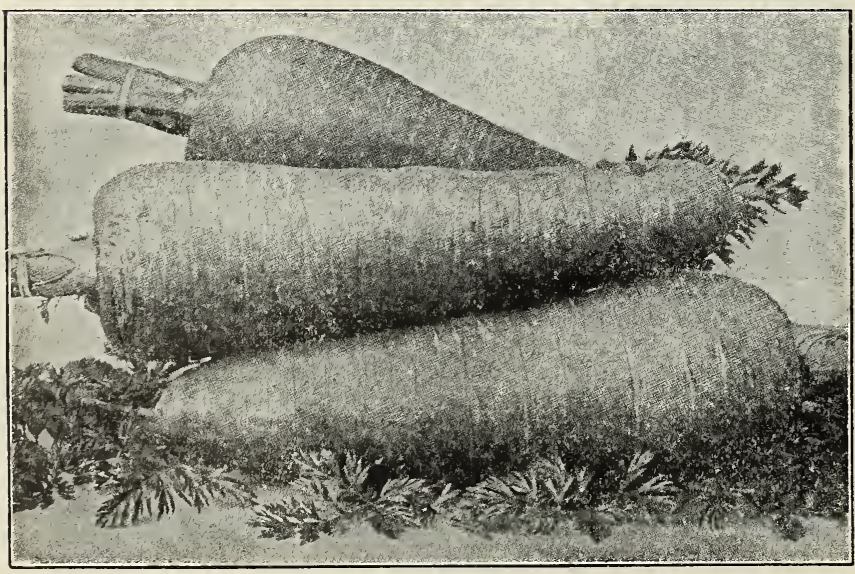

Danvers Half-Long
Chantenay or Model. A stump-rooted, medium-early, productive variety. Bright orange in color, smooth and of fine texture. Oz. 15 $11 / 4$ lb. $35 \phi$, lb. $\$ 1.00,5$ lbs. or more, per lb. $90 \phi$.

Danvers Half-Long. Produces well in almost any kind of soil. Medium long and perfectly smooth. Flesh deep orange, sweet, crisp and more, per lb. 90 \&.

Hutchinson. A great favorite with most gardeners. Root 10 to 12 inches long, nearly cylindrical in form ending in an abrupt stump root, deep orange color and immensely productive. Oz. $20 \notin, 1 / 4$ lb. 60 , lb. $\$ 2.00,5$ lbs. or more, per lb.

$\star$ Improved Danvers Orange. Favorite market variety and very extensively used in home gardens. Intermediate in size, a rich orange color and quality of the best. Oz. 15 $\phi, 1 / 4 \mathrm{lb}$. 35 .., lb. $\$ 1.00$, lbs. or more, per lb. 90 .

proved Long Orange. A very fine strain, valuable for both garden and field culture. The roots are long, with an even surface and deep orange flesh. Oz. $15 \phi, 1 / 4$ lb. $35 \phi, \mathrm{lb} . \$ 1.00,5 \mathrm{lbs}$.

Oxheart, or Guerande. A short and thick orangered Carrot; early and a most desirable table variety. Oz. $15 \phi, 1 / 4 \mathrm{lb}$. $35 \phi, \mathrm{lb}$. $\$ 1.00,5 \mathrm{lbs}$. or more, per lb. $90 \notin$.

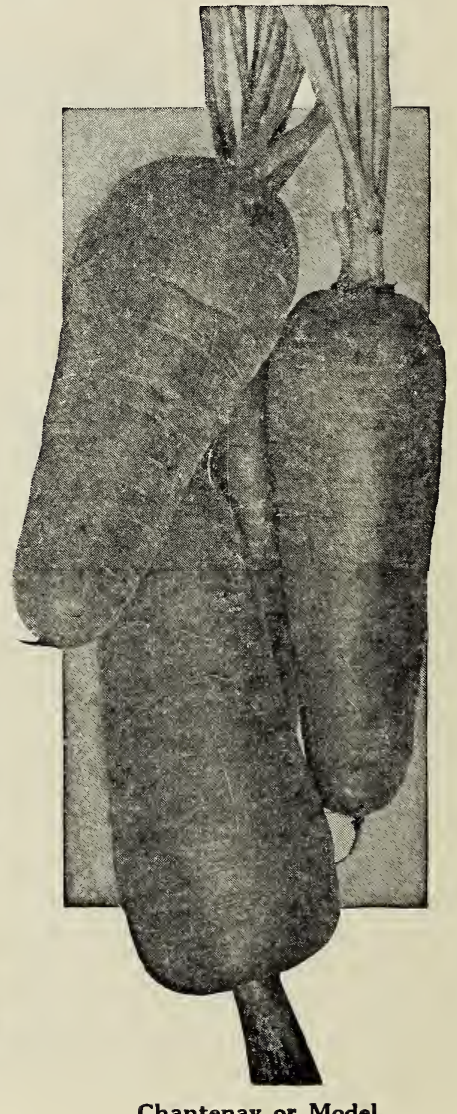

Chantenay or Model 


\section{cavoloflore GAUULTHLOWHR Kalafiory}

Culture-Cauliflower is easily grown if properly cared for. Many make the mistake of trying to get cauliflower to head in hot weather which is a difficult thing to do. To avoid this mistake it should be started in March or early April in greenhouse or hot bed and transplanted in good fertile soil soon as conditions will permit so it will head before hot summer weather sets in or sow in June and transplant when ready so that it will form heads in Autumn. Transplant in rows 2 to 3 feet apart and about 18 inches in the row. Cultivate freely to keep plants in good growing condition and when heads begin to form it is well to bunch the leaves together and tie loosely to keep the sun from the head. One ounce will produce 2000 to 3000 plants.

Dry Weather or Danish Giant. Quite similar to Snowball and especially well adapted to dry weather. $1 / 4 \mathrm{oz} .60$ c, $1 / 2 \mathrm{oz}$. $\$ 1.00$, oz. $\$ 1.75,1 / 4$ lb. $\$ 6.00$.

Early Paris. A reliable variety, suitable for early or late use, and producing large, compact, white heads. $1 / 4$ oz. $25 \hat{c}, 1 / 2$ oz. $40 \hat{c}$, oz. 75 c, $1 / 4$ lb. $\$ 2.50$.

$\star$ Henderson's Early Snowball. Extremely early and indispensable for all purposes through the Summer and Fall seasons. Well adapted for forcing under glass during Winter and Spring. Of vigorous growth and forming perfect heads of snowy whiteness. $1 / 4$ oz. 60 c, $1 / 2$ oz. $\$ 1.10$, oz. $\$ 2.00$, $1 / 4$ lb. $\$ 7.00$.

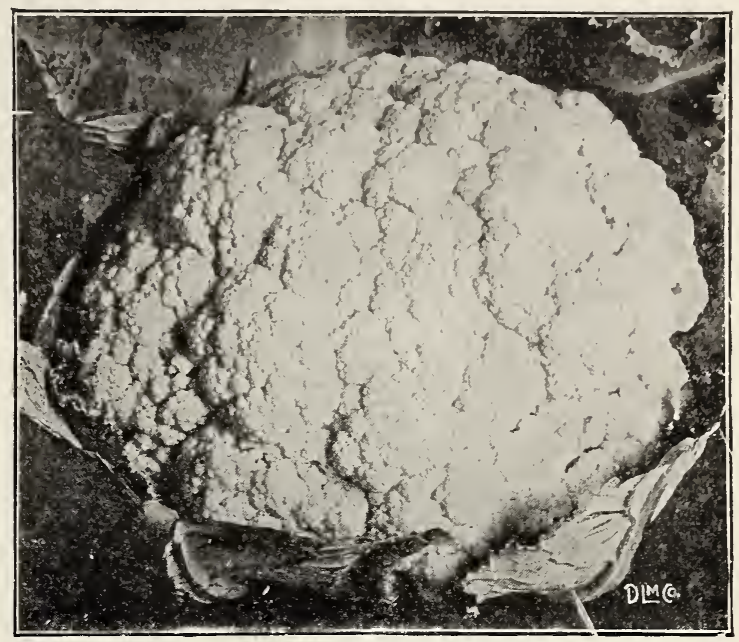

Henderson's Early Snowball

\section{SEDANo CELER Y SELERY}

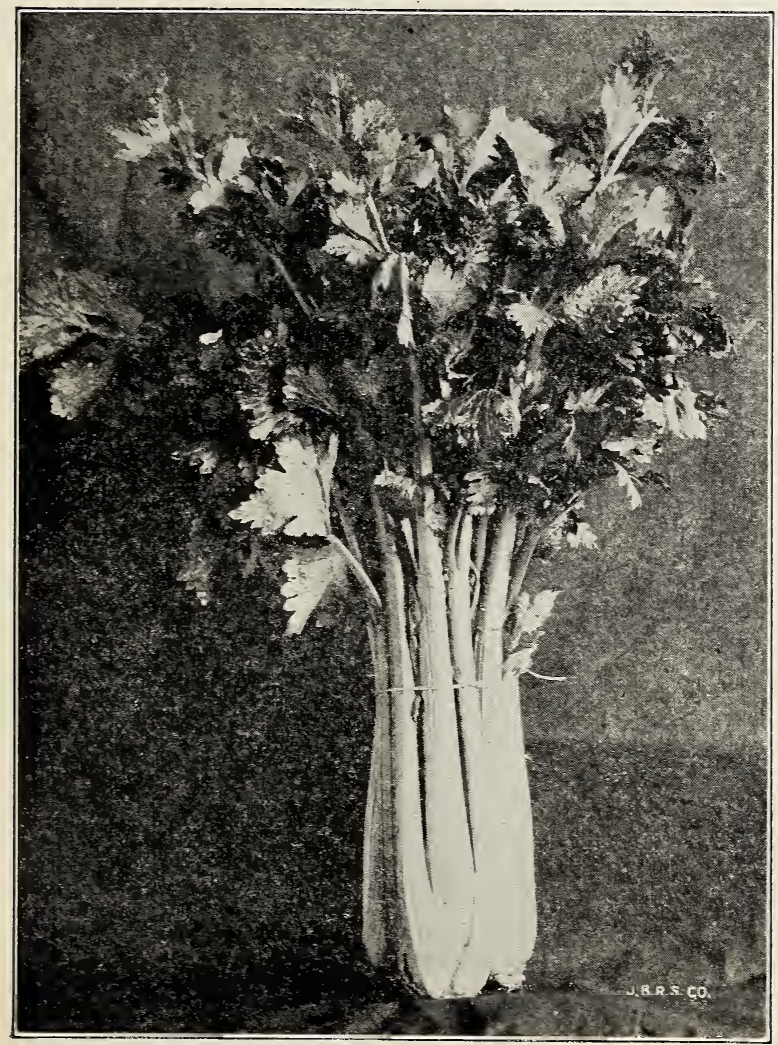

Easy Blanching
Culture - For both market and home use there is no more highly esteemed vegetable than Celery. As the seed is very small it demands intelligent and careful culture. Sow in drills 8 to 10 inches apart early in May, or as soon as the ground is entirely free from frost. The soil should be well pulverized and the seed lightly covered. An additional sowing or two between this period and June 15 will insure a plentiful supply of good plants. From about the middle of June to as late as the first week in August transplant in shallow trenches 3 to 4 feet apart, leaving a space of 2 to 4 inches between the plants in the row. Flat culture, without trenches, is advocated by many gardeners. Press the soil firmly about the roots and keep well cultivated. As Fall approaches "banking-up" for bleaching is started by bunching the leaves together and drawing the soil around the plants about one-third up; this is continued at intervals until only the leaves appear above the soil.

Blanching is often accomplished by means of boards or building paper set up against the rows instead of soil. Late Celery for Winter use should be pitted or placed in cellar before freezing weather. One ounce of seed will produce about 4,000 plants.

Columbia. A fine variety for home market and private garden. The stalks are very thick and nearly round. Its foliage is light green and blanches to almost a golden yellow and has a decidedly nutty flavor of very superior

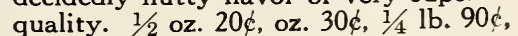
lb. $\$ 3.50$. 


\section{CELERY-Continued}

Easy Blanching. Resembles Paris Golden in growth, green leaves, and blanches white instead of yellow and more hardy. Matures about two weeks later. An excellent winter keeper as well as an early celery. $1 / 2$ oz. $35 \phi$, oz. $60 \phi, 1 / 4 \mathrm{lb}$. $\$ 2.10$, lb. $\$ 8.00$.

$\star$ Golden Plume or Wonderful. A new blight resisting variety cross between Easy Blanching and Golden Self-Blanching with the vigor of the Easy Blanching and the color of Golden SelfBlanching makes it a very valuable variety and has already become quite a favorite with many growers. $1 / 2$ oz. $60 \%$, oz. $\$ 1.10,1 / 4$ lb. $\$ 4.00$, lb. $\$ 15.00$.

Giant Pascal. A choice Celery with a sweet nutty flavor. Splendid keeper and a favorite. Blanches quickly with but slight earthing up. The stalks are thick, solid and brittle. $1 / 2$ oz. 15\&, oz. 25 \&, $1 / 4$ lb. 75 \&, lb. $\$ 2.50$.

Paris Golden Self-Blanching. (New strain French grown.) Extremely early, of handsome appearance, and recognized as one of the best money-making market garden Celeries grown. Also very desirable variety for the home garden. Self-blanching to a wonderful degree, the stalks are of a rich golden yellow color and of a delicious flavor. $1 / 2$ oz. $35 \phi$, oz. $60 \notin, 1 / 4$ lb. $\$ 2.10$, lb. $\$ 8.00$.
White Plume. An early and rapid growing white Celery; very easily blanched and of good flavor. Exceedingly popular in some sections of the country. $1 / 2$ oz. 15 \&, oz. 25 \&, $1 / 4$ lb. 75 \&, lb. $\$ 2.50$.

Winter Queen. One of the most valuable varieties for winter use. Of vigorous, compact growth and when ready for the market bench presents an exceptionally attractive appearance. Has an unusually large amount of heart, which possesses that agreeable, nutty flavor so much desired in Celery. $1 / 2$ oz. 15 , oz. 25 , $1 / 4$ lb. 75 , lb. $\$ 2.50$.

\section{CELERIAC, orTURNIP- ROOTED CELERY}

A kind of Celery, with large, round roots which are cooked like Beets or Turnips; also widely used for flavoring soups, etc.

Large Smooth Prague. An improved variety of Turnip-rooted Celery; roots very large, globe shaped, smooth skin and of fine quality. $1 / 2 \mathrm{oz}$. $15 \phi$, oz. $25 \phi, 1 / 4$ lb. $75 \phi$, lb. $\$ 2.50$.

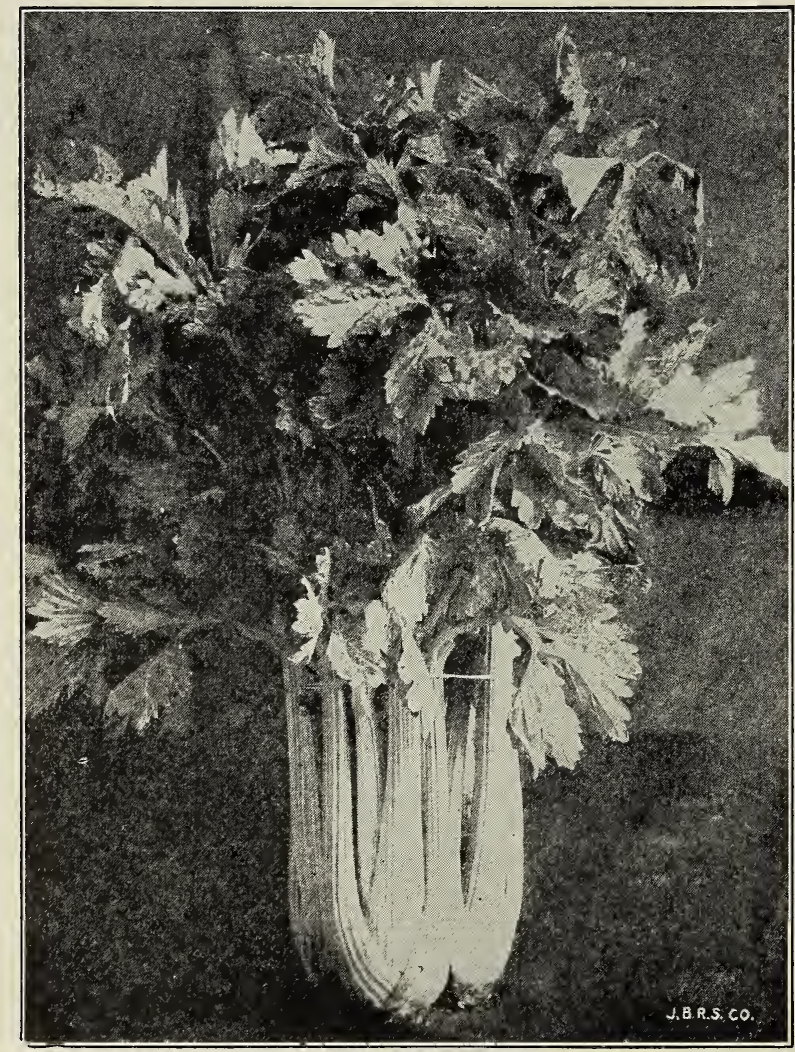

Paris Golden Self-Blanching 
Half bushel at bushel rate

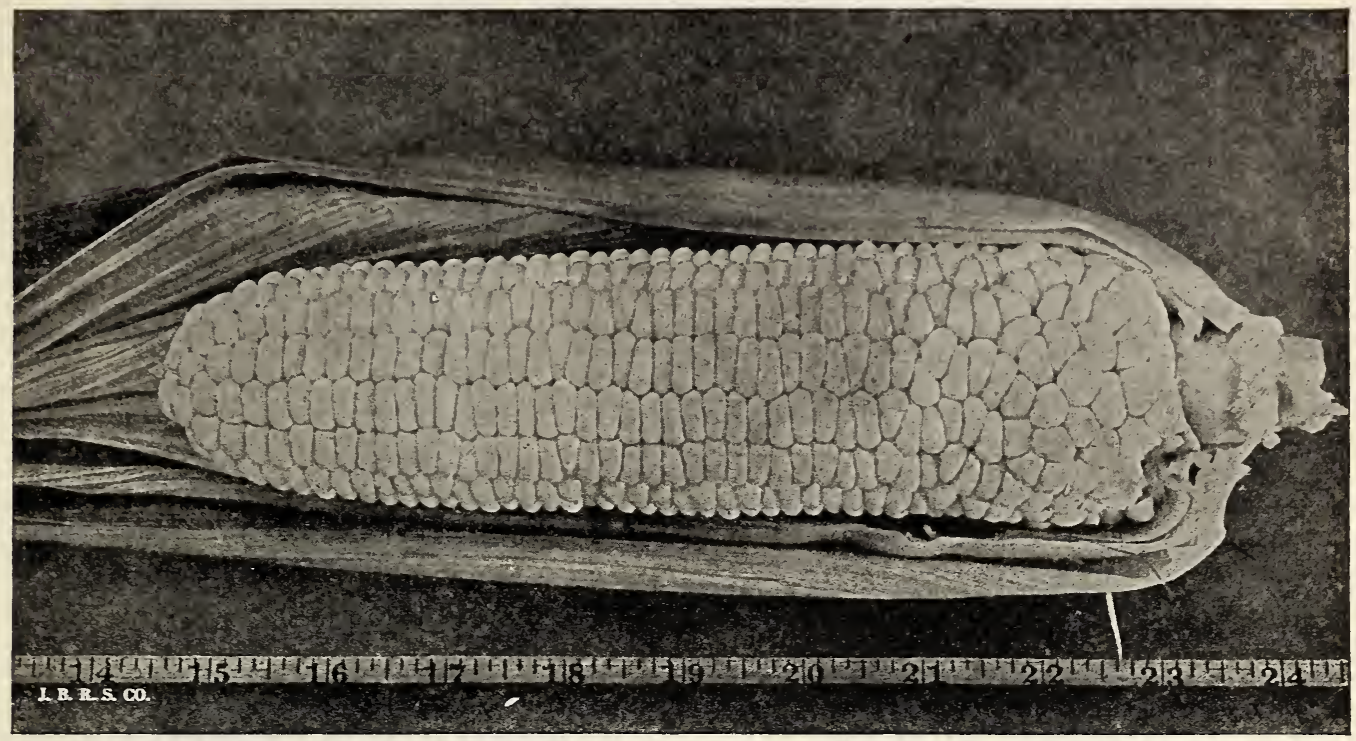

Extra Early Golden Gem

If you want corn that is sweet and has the genuine delicious New England sweet corn flavor try our corn that is grown here on our Connecticut seed farms.

Our New England grown sweet corn has an exceptionally fine flavor and is in great demand.

Culture - Sweet Corn requires good soil and responds to clean and frequent cultivation. Corn is usually planted in well-fertilized hills, 3 to $31 / 2$ feet a part each way. Put 5 to 6 kernels in each hill and cover with mellow soil to a depth of about $11 / 2$ inches. When the blades are about 6 inches high, and there is no further danger of injury from birds or insects, remove from each hill all but the three most vigorous stalks. Many gardeners sow the seed in rows 3 feet apart, leaving the plants standing singly about 9 inches apart. For a succession throughout the season, plant early in May several varieties, including first early to late. Or a good second early sort planted at intervals of two weeks until the first week in July will produce a continuous supply. One quart will plant about 200 hills, 8 to 10 quarts to an acre.

\section{* Extra Early Golden Gem}

An exceptional early type of Golden Bantam, maturing week to ten days earlier than that variety. Ears extra large for such an early corn containing 12 rows of broad golden yellow sweet grains, especially desirable for its earliness and fine quality, just the corn for market, private garden or roadside stand. Supply very limited. Pt. 30k, qt. 55k, 4 qts. $\$ 1.75$, pk. $\$ 3.25$.

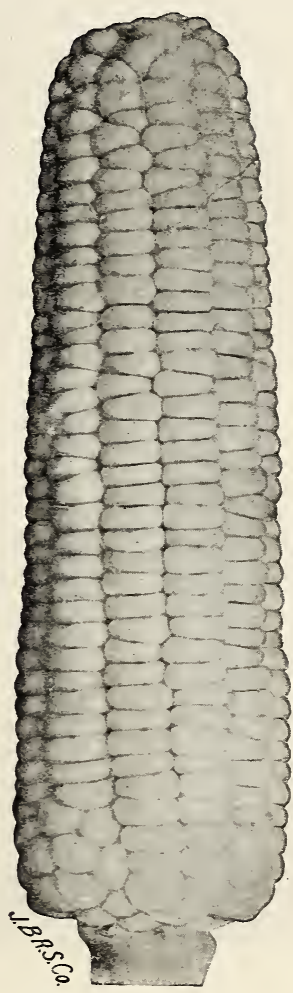

Extra Early Wonder 


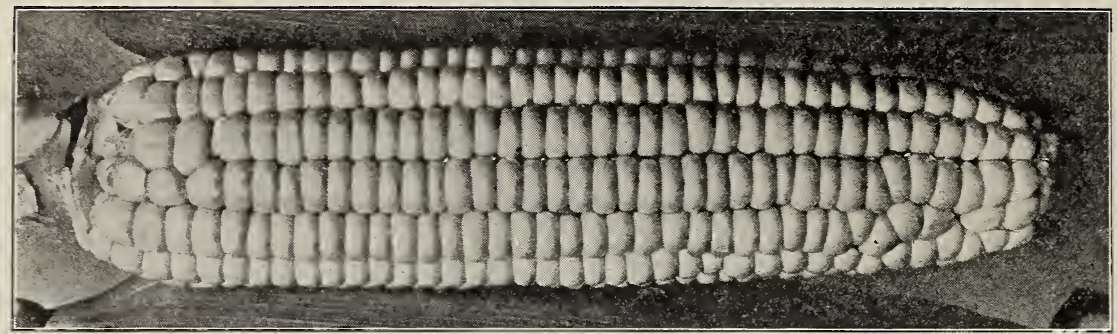

Golden Bantam

\section{$\star$ EXTRA EARLY WONDER}

A fine extra early corn with decided merit for the market gardener and anyone that wants a very early variety, being the first large eared white sweet corn ready for the market and table use. It grows an ear 6 to 8 inches long with 12 rows of moderate long, good sized white kernels of excellent quality, is a valuable variety for market and home consumption. $\mathrm{Pt}$. $30 \phi$, qt. $45 \phi, 4$ qts. $\$ 1.50$, pk. $\$ 2.75$, bus. $\$ 10.00$.

\section{$\star$ GOLDEN BANTAM}

This remarkable variety succeeds admirably under almost all conditions, and because of its earliness, vigor of growth, firmness of grain and truly delicious flavor it is a great favorite in all sections of the country. Attaining a height of about 5 feet, the sturdy stalk usually bears two or more medium-sized ears, which, when ready for the table, are of a rich golden yellow color very tender and delicious. Golden Bantam is especially well adapted to the home garden and a continuous supply may be maintained right through the season by successional planting. $\mathrm{Pt}$. 25 , qt. 40 , 4 qts. $\$ 1.30$, pk. $\$ 2.25$, bus. $\$ 8.50$.

\section{EXTRA EARLY MAYFLOWER CORN}

Extra early variety somewhat similar to Extra Early Wonder, grows large stalks and matures week later. Good sized ear, kernels white and very sweet. Worthy a place in your garden. Pt. 25ф, qt. 40 c, 4 qts. $\$ 1.30$, pk. $\$ 2.25$, bus. $\$ 8.50$.

\section{WHIPPLE'S EARLY}

A fine early variety that has proven to be quite popular, ready for use about same time as Golden Bantam. A vigorous grower of large ears with 16 to 20 rows of long pure white kernels, fine quality. Pt. $25 \phi$, qt. 40 \&. 4 qts. $\$ 1.30$, pk. $\$ 2.25$, bus. $\$ 8.50$.

\section{$\star$ GOLDEN GIANT (DE LUE'S)}

This variety is week or ten days later than Colden Bantam and on good soil will yield abundantly of quite large, beautiful golden yellow ears of fine flavor and stays in the green stage longer than many other varieties which makes it a valuable table and market corn. Pt. 30غ, qt. $45 \phi, 4$ qts. $\$ 1.40$, pk. $\$ 2.35$, bus. $\$ 9.00$.

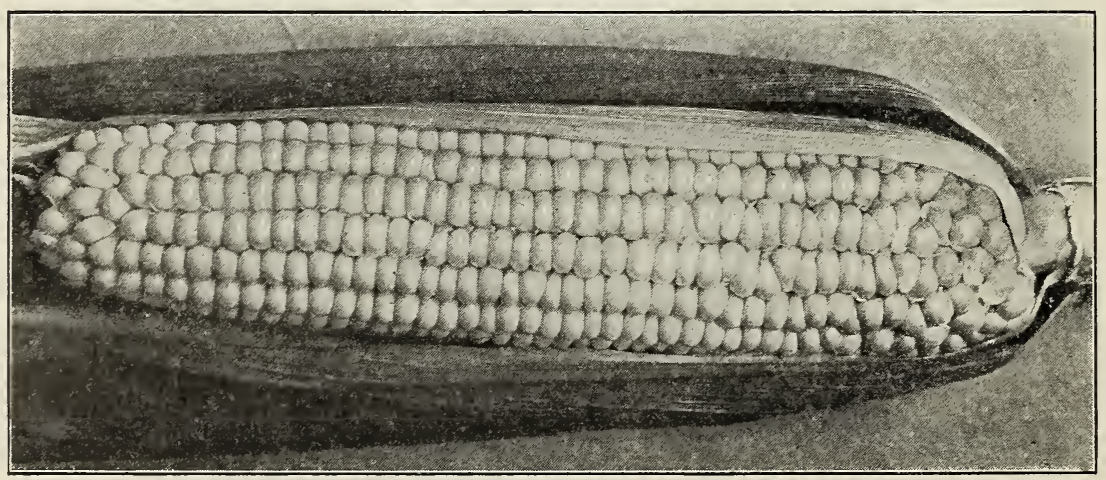

De Lue's Golden Giant 


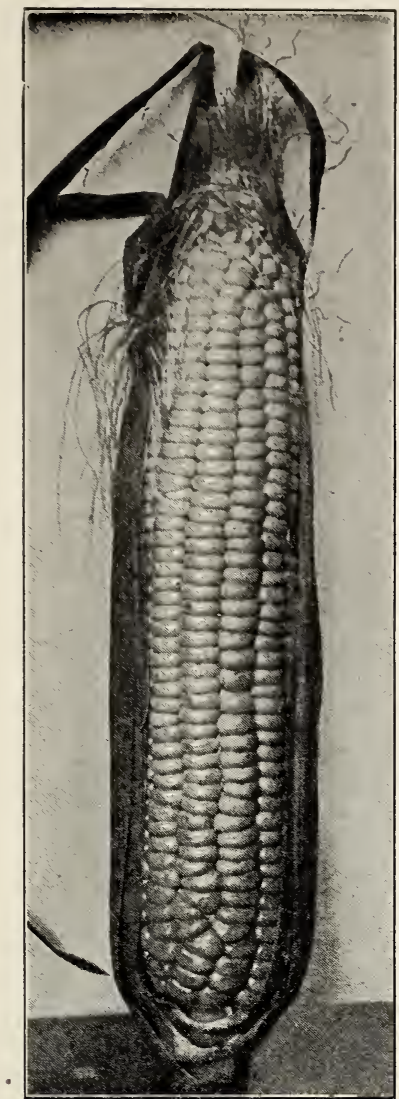

Howling Mob

\section{EARLY CHAMPION}

A most desirable medium-early Sweet Corn, extremely valuable for both market and home use. The liberal sized attractive ears have ordinarily 12 rows of clear, white grains of superior quality. The large and leafy stalks make first-class fodder. Pt. 25ḱ, qt. 40 é, 4 qts. $\$ 1.30$, pk. $\$ 2.25$, bus. $\$ 8.50$.

\section{* HOWLING MOB}

A very popular medium early variety and very productive. Ears 9 to 10 inches in length with large white kernels of excellent quality. Pt. 25\&. qt. 40\&. 4 qts. $\$ 1.30$, pk. $\$ 2.25$, bus. $\$ 8.50$.

\section{BLACK MEXICAN}

A distinctive second-early variety, in considerable demand in some sections. The kernels, which are purplish black when ripe, are exceedingly tender and sweet flavored. Pt. 30 \&, qt. $45 \xi, 4$ qts. $\$ 1.40$. pk. $\$ 2.35$, bus. $\$ 9.00$.

\section{WHIPPLE'S YELLOW}

A medium early large eared variety, that matures about same time as Golden Giant. The ears are well up from the ground, long and large with 12 to 16 rows of rich yellow colored kernels of finest quality. Pt. 30 , qt. $45 \xi, 4$ qts. $\$ 1.40$, pk. $\$ 2.35$, bus. $\$ 9.00$.

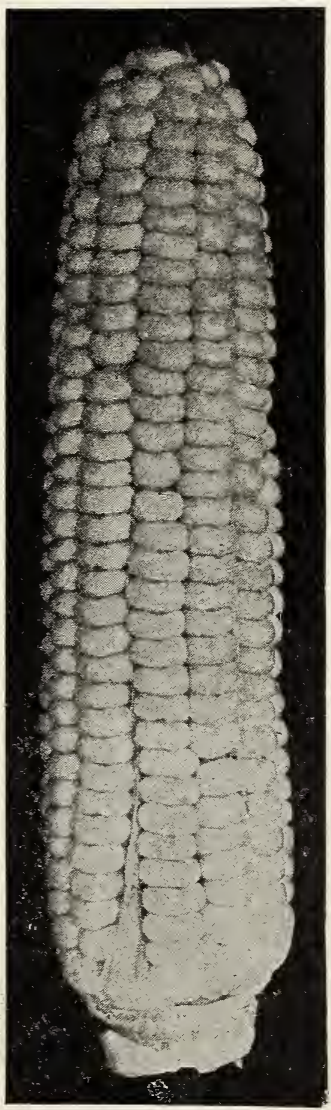

Whipple's Yellow 


\section{SWEET CORN-Continued}

\section{$\star$ STOWELL'S EVERGREEN}

This splendid main crop Sweet Corn has long been recognized as unrivaled for both private garden and market use. It is popular everywhere and probably more extensively cultivated than any other variety. The ears grow to a large size, with deep grains, very tender and sugary, and remain for a long period in good condition for cooking. Because of its strong and vigorous growth and abundant foliage, Stowell's Evergreen is also sown by many farmers and dairymen for fodder. $\mathrm{Pt} .25 \dot{\phi}$, qt. $40 \& .4$ qts. $\$ 1.30$, pk. $\$ 2.25$, bus. $\$ 8.50$.

\section{COUNTRY GENTLEMAN}

We recommend Country Gentleman as a peculiarly valuable sort for table use. Classed as a late or main crop variety, it is very prolific and yields fine, good sized ears filled with irregular rows of luscious, tender and milky grains. Pt. $30 \phi$, qt. $45 \phi$, 4 qts. $\$ 1.40$, pk. $\$ 2.35$, bus. $\$ 9.00$.

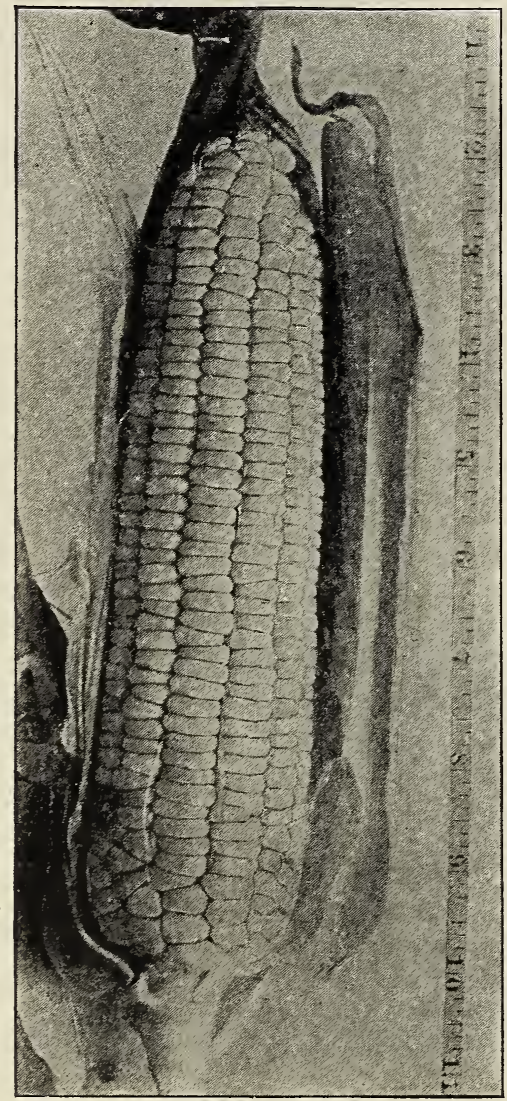

Stowell's Evergreen

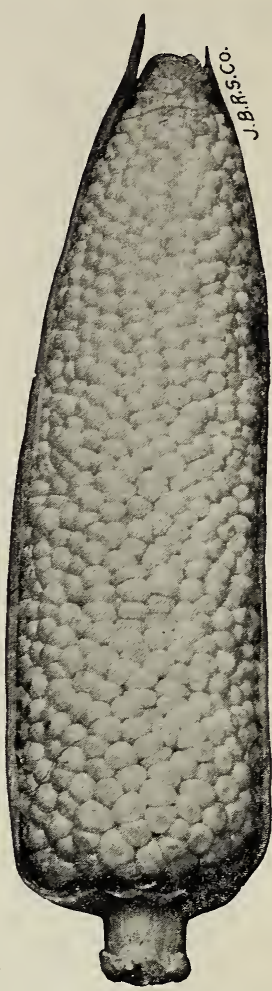

Country Gentleman

\section{FIELD AND ENSILAGE CORN -}

\section{See pages 35,36 and 37 \\ CORN SALAD, or FETTICUS}

VALERIANA

ZRAINO SALATZ

Culture - This is a most useful, hardy Winter salad. Largely used as a substitute for Lettuce. It may also be cooked and prepared like Spinach. Sow in Spring in drills 1 foot apart; matures in six or eight weeks, but it does not thrive well in very hot weather. For Winter and early Spring use, sow in August or September. One ounce will sow 100 feet of drill.

Broad-Leaved. Oz. $15 \xi, 1 / 4 \mathrm{lb} .40 \xi, \mathrm{lb} . \$ 1.50$. 


\section{CUCUMBERS}

CETRIOLO

OGOREK

Culture - Cucumbers flourish best in rich, warm, loamy soil. When the weather has become thoroughly settled and warm plant in hills 4 to 5 feet apart each way, putting 10 to 12 seeds in each hill. As plants appear above the surface they should be diligently watched and protected against the ravages of many insect enemies. This may be effectively accomplished by sprinkling land plaster, ashes, tobacco dust or other insecticide on the hills when moist from rain or dew. Finally, thin the young plants to four to each hill. For a succession continue planting at intervals. Fruits should not be left on the plants long enough to ripen, as this diminishes productiveness. For pickles, plant in late June and first week in July. One ounce will plant about 50 hills, 3 pounds to the acre.

Boston Pickling. A favorite with those who appreciate a pickling "cuke" of superior quality. The fruit is medium long, rich green in color, crisp and tender. Useful for slicing. Oz. $10 \notin, 1 / 4 \mathrm{lb}$. 30 k, lb. $\$ 1.00,5 \mathrm{lbs}$. or more, per lb. 90 ć.

^ Davis' Perfect. An extra long dark green type of white spine very valuable for forcing under glass as well as for growing out of doors; the vines are exceedingly prolific. The Cucumbers are long, handsome and regular in form and of a beautiful, glossy green color; while the solid flesh is of superb quality fine for pickles or slicing. Oz. 15k, 1/4 lb. 40 , lb. $\$ 1.40,5$ lbs. or more, per lb. $\$ 1.30$.

Early Cluster. One of the old strains and extensively planted in some sections. An abundant bearer, the fruits generally setting in clusters. When small they are desirable for pickling. Good quality and flavor. Oz. 10k, 1/4 lb. 30k, lb. $\$ 1.00,5$ lbs. or more, per lb. 90 k.

$\star$ Extra Early Long Green. Resembles Improved Long

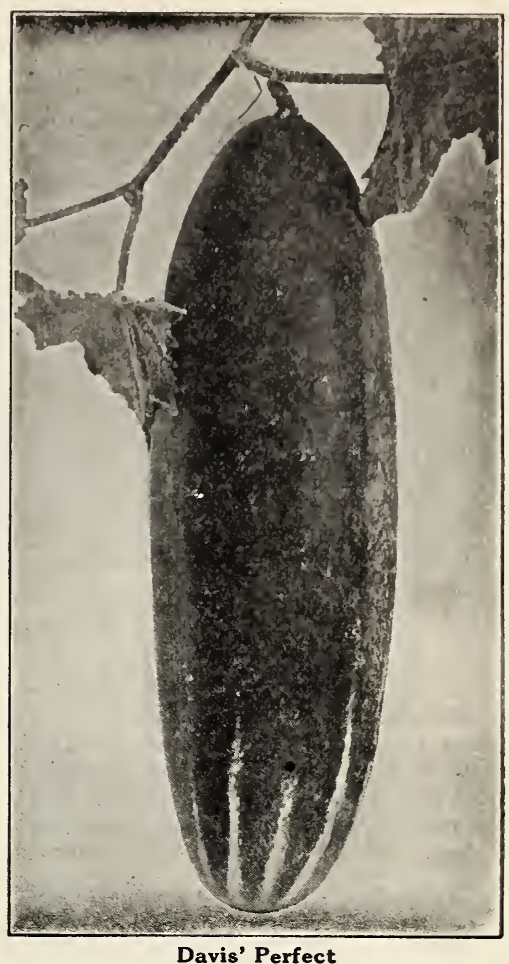

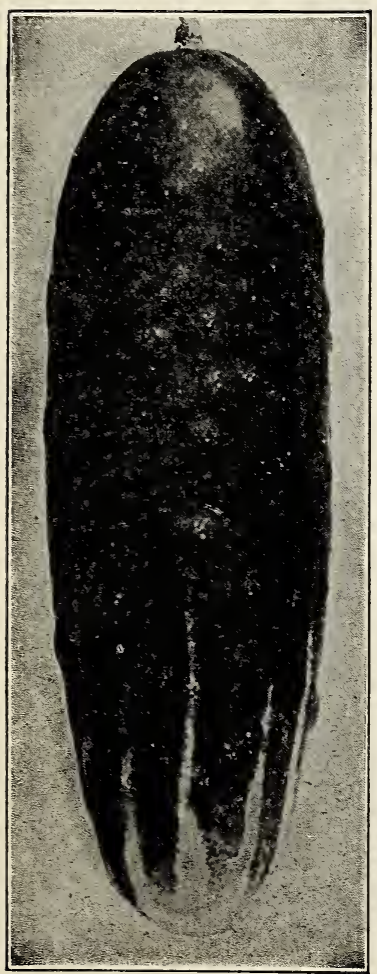

Extra Early Long Green
Green in growth and shape. About two weeks earlier. Excellent variety for early pickles and slicing. Oz. $15 \notin, 1 / 4 \mathrm{lb} .40 \notin, \mathrm{lb} . \$ 1.40$. $5 \mathrm{lbs}$. or more, per lb. $\$ 1.30$.

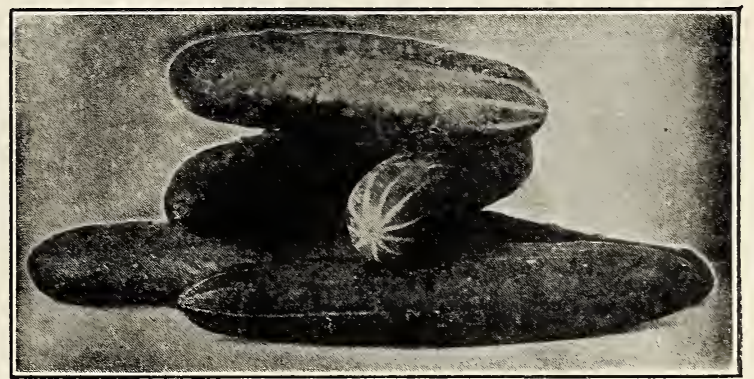

Extra Long White Spine

$\star \quad$ Extra Long White Spine. Vines are vigorous with heavy foliage, and yield in great profusion long, slim fruits. Dark green when young: tender and brittle. Fine for pickles. Oz. 15ধ, 1/4 lb. 40k, lb. \$1.40, $5 \mathrm{lbs}$. or more, per lb. $\$ 1.30$.

Fordhook Famous. It is of the White Spine type, retaining its beautiful dark green color for a long time. The fruit is long, thick and tapering at both ends, crisp and tender. Valuable for both slicing and pickling. $\mathrm{Oz}, 15 \xi .1 / 4 \mathrm{lb} .40 \xi, \mathrm{lb} . \$ 1.40,5 \mathrm{lbs}$ or more, per lb. $\$ 1.30$.

Improved Long Green. A healthy, vigorous grower, and a very free producer. Fruits dark green, tender, brittle and of fine flavor. The small Cucumbers are very generally used for pickling, while the more mature ones make excellent sweet pickles. Oz. $15 \dot{k}, 1 / 4 \mathrm{lb} .40 k, \mathrm{lb}$. $\$ 1.40,5$ lbs. or more, per lb. $\$ 1.30$.

$\star$ Improved Early White Spine. A popular, standard variety. 


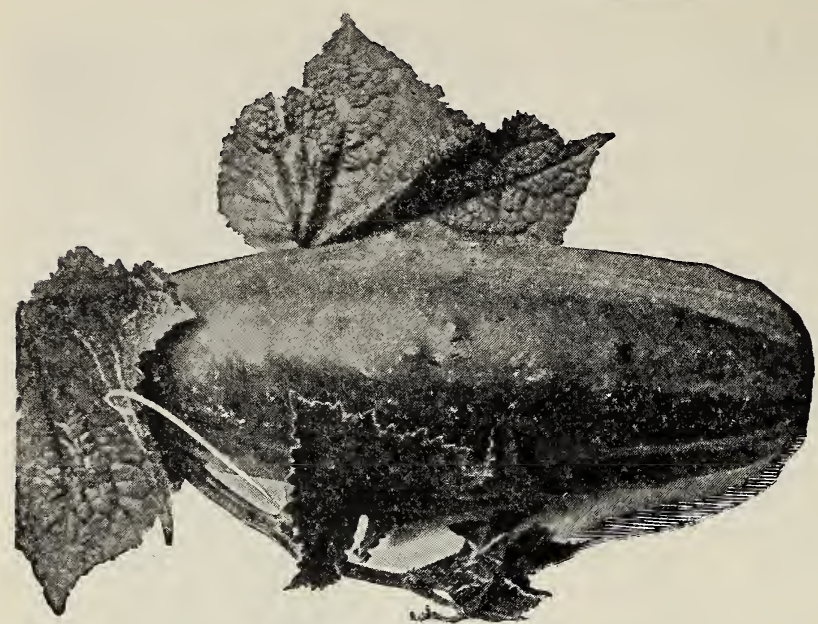

CUCUMBERS-Continued

producing an early crop of smooth, light green Cucumbers, tender and crisp, and highly esteemed for either family use, marketing or pickling when small. Oz. $10 \phi, 1 / 4 \mathrm{lb} .30 \phi, \mathrm{lb}$. $\$ 1.00,5$ lbs. or more, per lb. $90 \phi$.

Thorburn's Everbearing. This unique and highly meritorious pickling variety is a favorite with many. It is undoubtedly one of the best sorts to plant where extra small Cucumbers of good quality are required for pickling purposes. The vines are of sturdy growth and enormously productive, bearing until halted by frost. Oz. 15k, 1/4 lb. $40 \xi$, lb. $\$ 1.40,5$ lbs. or more, per lb. $\$ 1.30$.

Improved Early White Spine

\section{AGRETTO CRESS OT PEPPER GRASS RZERZUCHA}

Culture - This is a well-known, wholesome, little intervals for succession. One ounce will sow about plant of appetizing piquancy and much used for salad and garnishing. When the ground is clear of frost sow thickly in drills 6 to 8 inches apart, covering very lightly. It is of very rapid growth, and as 150 feet of drill. it soon runs to seed should be sown at frequent

Extra Curled. The leaves of this variety are crisp, pungent, finely curled and ornamental in appearance. $1 / 2$ oz. $10 \phi$, oz. $15 \phi, 1 / 4$ lb. $35 \phi, \mathrm{lb} 60 \phi$.

\section{ENDIVIA ENDIVE ENDYWIA}

Culture-One of the most attractive and refreshing of Autumn and Winter salads. Sow from the middle of June till the end of August in shallow drills 15 to 20 inches apart and thin to 8 or 10 inches. Should be well watered in dry weather. In the Autumn Endive may be blanched by tying the leaves together. One ounce will sow 150 feet of drill.

Broad-leaved Batavian. (Escarole). Broad, thick leaves. Popular market variety. $1 / 2$ oz. $10 \phi, o z$ $15 \&, 1 / 4$ lb. $40 \&, \mathrm{lb} . \$ 1.00$.

Green Curled. Beautifully curled, deep green leaves. Hardy and useful for Fall and Winter. $1 / 2$ oz. $10 \phi$, oz. $15 \phi, 1 / 4$ lb. $40 \phi$, lb. $\$ 100$.

\section{DENTE DI LEONE DANDELION PAPAWA}

Culture - The Dandelion is cultivated for its fine young leaves, and is one of the earliest and most healthful of Spring greens. Sow the seed in well manured soil any time from early Spring until Fall. Sow in drills 12 inches apart and thin to 3 inches. One ounce will sow 100 feet of drill.

$\star \quad$ Large French Cut-leaved. A very early, cultivated common cut leaved variety extensively sown for early greens. $1 / 2$ oz. $20 \notin$, oz. $35 \phi, 1 / 4$ lb. $\$ 1.25$, lb. $\$ 4.00$.

Improved Thick Leaved. An improved variety, thick broad leaves and grows more upright. A valuable market variety as well as for home use. $1 / 2$ oz. $35 \phi$, oz. $60 \dot{\phi}, 1 / 4$ lb. $\$ 2.25$, lb. $\$ 8.00$.

\section{Petronciano EGG-PLANTGRUSZKA}

Culture - Good treatment is well rewarded in the cultivation of this very desirable and popular plant, appreciated alike by the private gardener and the grower for market. Sow in the hotbed in February and March, and when the plants are 2 or 3 inches high thin to 3 inches or prick into a second bed or small pots. Transplant in the open ground in May and early June in rows 3 feet apart and 2 feet a part in the row. One ounce will produce about 1,000 plants. $\star$ Black Beauty. Earlier than New York Improved and an excellent sort for market and home use. A bountiful yielder of shapely, purple-black fruits of fine quality. $1 / 2$ oz. 20 \&, oz. $35 \dot{\phi}, 1 / 4$ lb. $\$ 1.25$, lb. $\$ 4.00$.

New York Improved Purple. A standard variety, producing a liberal crop of rich purple fruits, smooth and glossy. $1 / 2$ oz. $20 \notin$, oz. $35 \phi, 1 / 4$ lb. $\$ 1.25, \mathrm{lb} . \$ 4.00$.

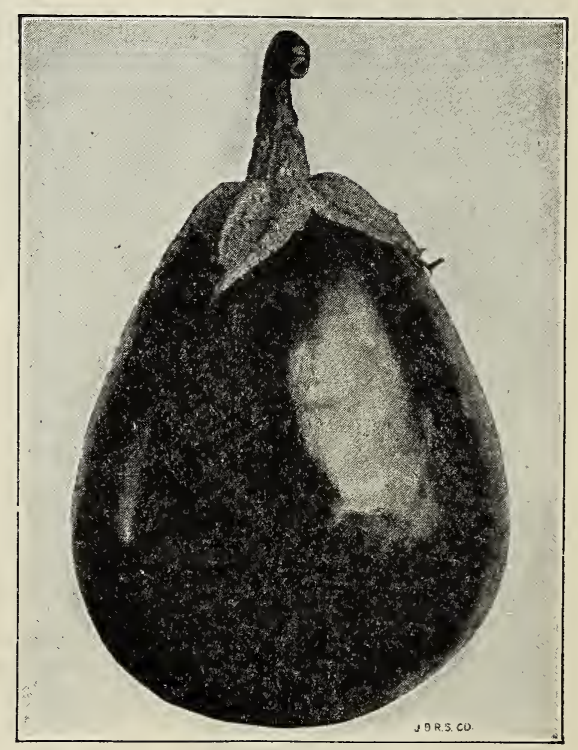

Black Beauty 


\section{HERBS}

Caraway. A biennial herb. Grown for its seeds which are used for flavoring bread, cakes, etc. Grows about two feet high. $1 / 2$ oz. 10 . oz. 15 . $1 / 4$ lb. 30 ć, lb. 90 ć.

Dill. An annual herb. The seeds are used for seasoning. The foliage is also used for flavoring and medicinal purposes, and largely used in pickles in what is known as dill pickles. $1 / 2 \mathrm{oz}$. 5 c, oz. 10 k. $1 / 4$ lb. 25 c, lb. 75 c.

Fennel. A hardy perennial. The stems are used in soups, garnishes and salads. The seed is also relished by many. $1 / 2$ oz. 10 , oz. $15 \%, 1 / 4 \mathrm{lb}$. 35 c. lb. $\$ 1.25$.

Lavender. A hardy perennial used to make lavender water or dried and used as perfume for linen, etc. $1 / 2 \mathrm{oz} .15 \%$, oz. $25 \%, 1 / 4 \mathrm{lb} .80$. lb. $\$ 3.00$.

Sage. A perennial herb, possessing medicinal properties, but largely used for flavoring and stuffing. $1 / 2$ oz. 20 \&, oz. 35 \&, $1 / 4$ lb. $\$ 1.10,1 b . \$ 4.00$.

Summer Savory. A hardy annual. The stems and leaves are used principally for flavoring

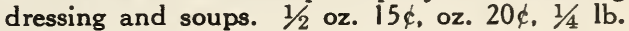
60 c. lb. $\$ 2.00$.

Sweet Marjoram. A half hardy perennial. The leaves are used both green and dried for seasoning: and flavoring. $1 / 2$ oz. $15 \xi$, oz. 25 k. $1 / 4 \mathrm{lb}$. 80 . lb. $\$ 3.00$.

\section{cavolo verde $K A L E$, or BORECOLE solanka}

Culture - Hardier than Cabbage, this vegetable makes splendid greens for Winter and early Spring use. The flavor is improved by frost. Sow from middle of April to beginning of May in prepared beds and when transplanted give the plants the same cultivation as Cabbage. One ounce will yield about 2,000 plants. For early Spring use sow in September and cover with hay through winter. $\star$ Dwarf Curled Scotch. Bright green leaves, nicely curled and of delicate flavor. $1 / 2 \mathrm{oz} .10 \%$. oz. 15 k, $1 / 4$ lb. 35 \&. lb. $\$ 1.00$.

Green Curled Scotch. A half tall-growing variety, tender and sweet. $1 / 2$ oz. $10 \AA$. oz. $15 \xi$. $1 / 4$ lb. 35 k. lb. $\$ 1.00$.

\section{caVolo rapa KOFIL-RABI KALAREPA}

Culture - This peculiar vegetable partakes of the character of both Cabbage and Turnip, and is quite popular. The edible portion consists of large bulbs which form on the stems immediately above the soil, and when cooked like Turnips are very delicious. They should be gathered before the skin hardens. Sow in Spring in rows 18 inches apart and thin the plants to 8 or 10 inches. One ounce will sow 200 feet of drill.

$\star$ Early White Vienna. Very desirable variety for general use. Has small top and is early. Color light-silvery green. $1 / 2 \mathrm{oz} .10 \xi, \mathrm{oz} .15 \xi, 1 / 4$ lb. 50 ć, lb. $\$ 1.75$.

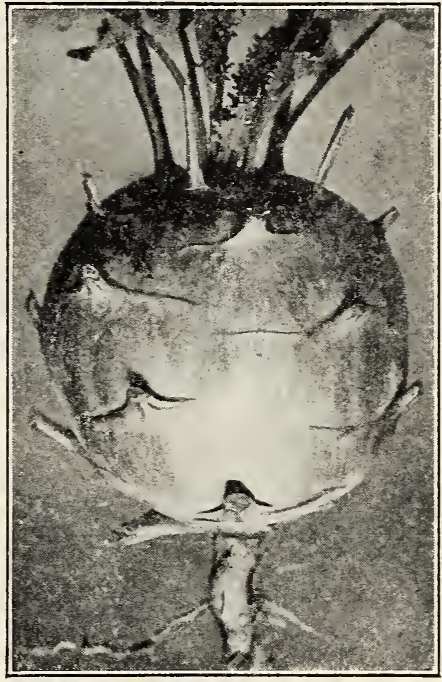

Early White Vienna

\section{PORRO LEEK PORY}

Culture - A hardy species of onion with long stem and not much bulb and thrives best in a light but well-enriched soil. Sow very early in Spring, in drills about 15 inches apart and 1 inch deep. When the plants are 4 to 6 inches high thin to about 4 inches or can be transplanted if desired. To insure well-blanched necks or stems set as deep as possible, and draw the soil up as the plants increase in growth. One ounce will sow 100 feet of drill. $\star$ American Flag. The most desirable sort for general use. $1 / 2$ oz. 10 , oz. 15 \&. $1 / 4 \mathrm{lb}$. 50 . lb. $\$ 1.75$.

Large Musselbuirg. Grows to a very large size; broad leaves and heavy stems. $1 / 2 \mathrm{oz} .10 \AA$, oz 15 \&. $1 / 4$ lb. 50 \&. lb. $\$ 1.75$. 


\section{LATTUGa LETTUCE}

\section{SALATA}

Culture - This palatable salad plant is so easily cultivated that everyone who has a garden finds a desirable spot for it; market gardeners also regard it as one of their most profitable crops. It prefers rich, moist soil, and to be crisp and tender should be grown quickly. For early use sow seed in hotbed or boxes during February and March, and as soon as the open ground is in workable condition transplant in rows about 18 inches apart and 8 to 10 inches in the row. For later use Lettuce may be sown at intervals from April through the Summer, thinning the plants to the proper distance in the rows, but best heads are grown by transplanting. One ounce will produce about 3,000 plants.

Big Boston. (White seeded). A fine variety for forcing and garden culture. The light green heads are large, handsome and of superior quality. $1 / 2$ oz. $15 \phi$, oz. $20 \notin, 1 / 4$ Ib. 50 , lb. $\$ 1.75$.

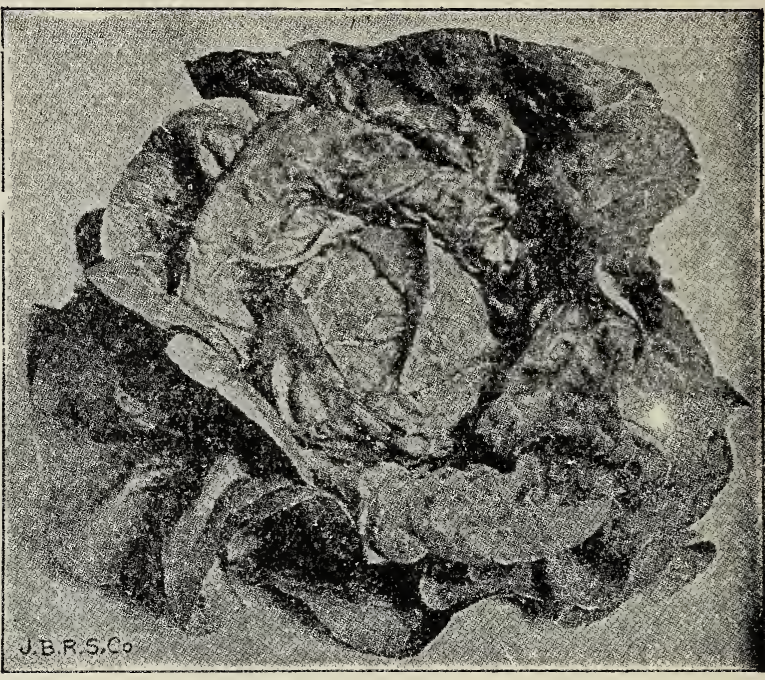

May King

Early Curled Black-seeded Simpson. One of the earliest curled varieties. Loose heads. $1 / 2$ oz. 15 , oz. 20 k, $1 / 4$ lb. 50 k, Ib. $\$ 1.50$.

Early Curled White-seeded Simpson. A popular variety, with fine loose heads of curly, crisp leaves. $1 / 2$ oz. $15 \%$, oz. $20 \%, 1 / 4$ lb. $50 \%$, lb. $\$ 1.50$.

Early Prize Head. Large, loose head, bright green leaves tinged with brown; quality excellent. $1 / 2$ oz. 15 \&, oz. $20 \%, 1 / 4$ lb. $50 \%$, lb. $\$ 1.50$.

Early White-seeded Tennis Ball or Boston Market. A compact-heading variety; medium size, with crisp, green leaves. Good for forcing or outdoor culture. $1 / 2$ oz. $15 \phi$, oz. $20 \notin, 1 / 4 \mathrm{lb} .50$. lb. $\$ 1.50$.

$\star$ Hartford Bronzed Head. A Butter Cabbage heading variety, slow to run to seed, leaves are broad, thick and quite crumpled, color varying

\section{Big Boston}

Big Boston. (Black seeded). An excellent strain of Big Boston, producing black seeds. The heads are larger than the white seeded variety and equally as firm. $1 / 2 \mathrm{oz}$. 15 , oz. 20 , $1 / 4$ lb. 50 \&, lb. $\$ 1.75$.

Brittle Ice. This lettuce forms a large compact head of light green leaves well bleached in the center, crisp and tender. $1 / 2$ oz. $15 \phi, o z$. 20 \&. $1 / 4$ lb. 50 \&, lb. $\$ 1.75$.

Dreer's All Heart. A reliable cabbage heading lettuce, well adapted to both Spring and Summer use as it withstands intense heat, forming heads of yellowish-green colored leaves of excellent flavor. $1 / 2$ oz. 15 , oz. $20 \phi, 1 / 4$ lb. $50 \phi$, lb. $\$ 1.75$.

Early Black-seeded Tennis Ball. Compact, well-formed heads, of excellent flavor. $1 / 2$ oz. $15 \phi$, oz. 20 c, $1 / 4$ lb. 50 \&, Ib. $\$ 1.75$.

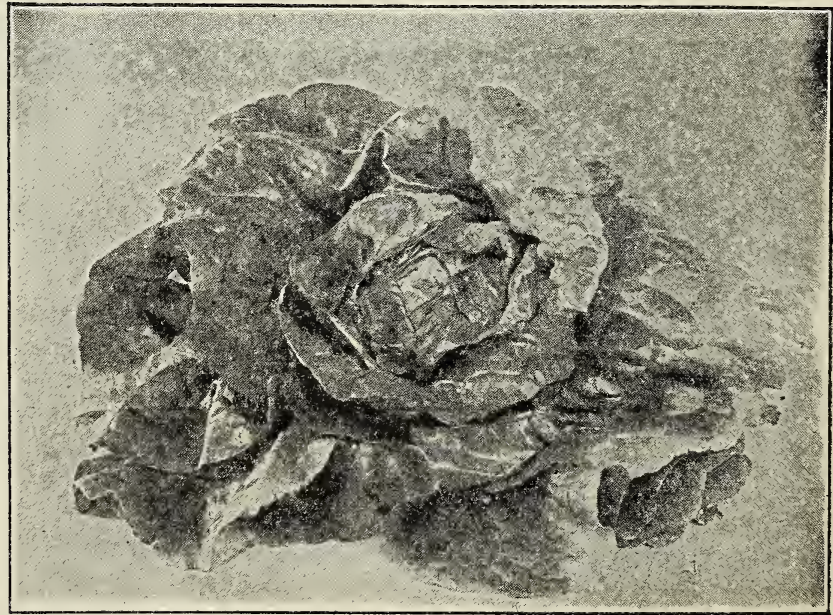

Salamander 


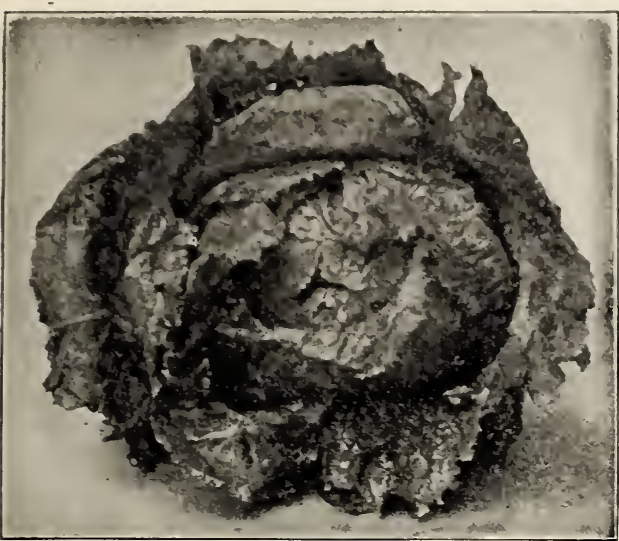

Wayahead

from bright green to dark brown; quality, excellent; a great favorite in vicinity of Hartford. $1 / 2$ oz. 15 c, oz. 20 c. $1 / 4$ lb. 50 c, lb. $\$ 1.50$.

Grand Rapids. Black seed. Forms large bunches of pale green, crumpled leaves, which are exceedingly sweet and brittle. Valuable for forcing or field culture in the Spring. $1 / 2$ oz. $15 \dot{c}$, oz. $20 \dot{c}$, $1 / 4$-lb. 50 c, lb. $\$ 1.75$.

$\star$ Iceberg. A hard-heading variety, always crisp and tender. Good for either early or late planting. $1 / 2$ oz. 15 k. oz. 20 k. $1 / 4$ lb. 50 k. lb. $\$ 1.75$.

Improved Hanson. Very sweet and crisp; reliable head variety for the family garden. $1 / 2$ oz. 15 k, oz. 20 k, $1 / 4$ lb. 50 k, lb. $\$ 1.75$.

$\star$ May King. Early, of quick growth, hardy and suitable for either forcing or outside culture. Fine, solid heads, with light green outer leaves and rich, golden yellow hearts, ideal flavor. A little tinged with reddish brown at edges of leaves. $1 / 2$ oz. 15 c, oz. 20 k, $1 / 4$ lb. 50 c, lb. $\$ 1.75$.

New York Head. Known by many gardeners as Los Angeles, Dark Green Iceberg and Wonderful. One of the best heading varieties. The heads are large, quite solid and inside leaves well blanched, rich nutty flavor. $1 / 2$ oz. 15 k, oz. 25 k, $1 / 4 \mathrm{lb} .60$, lb. $\$ 2.00$.

$\star$ Salamander. Good-sized, compact head, tender, sweet and buttery. One of the best for resisting Summer heat. $1 / 2$ oz. $15 \xi$, oz. 20 , $1 / 4$ lb. 50 c, lb. $\$ 1.75$.

Trianon Cos, or Romaine. Very popular and one of the best of this type of Lettuce. The oval heads are especially crisp and have a mild and pleasing flavor. They are easily blanched by loosely tying the outer leaves together at the top. $1 / 2$ oz. 15 c, oz. 20 c. $1 / 4$ lb. 50 c, lb. $\$ 1.50$.

Wayahead. A very early variety, forming fine heads, few weeks after transplanting. It is medium sized, light green heads, crisp and tender. $1 / 2$ oz. 15 c, oz. 20 c, $1 / 4$ lb. 50 \&, lb. $\$ 1.75$.

\section{popone MUSKMELONS MELON}

Culture - Well enriched, light soil is an important requisite for success in the growing of these choice Summer fruits. Early in May, when the ground is warm and dry, plant in hills 4 feet apart each way, 10 to 12 seeds to a hill. As soon as the plants make their appearance they are liable to attack by destructive insects. These should be fought with a dusting of soot, wood ashes, or some other good exterminator. When danger of these pests is over, thin out to 3 or 4 plants to each hill, and keep up cultivation until the vines nearly cover the ground. Occasional spraying with some effective insecticide is advisable. One ounce of seed will plant about 50 hills; 2 pounds to an acre.

Bender's Surprise. Very popular variety in some sections. Large oblong melon, little flat at the ends and fairly well netted greenish yellow skin when ripe, salmon colored flesh of good quality. Oz. 15 k, $1 / 4$ lb. 40 k, lb. $\$ 1.50,5$ lbs. or more, per lb. $\$ 1.35$.

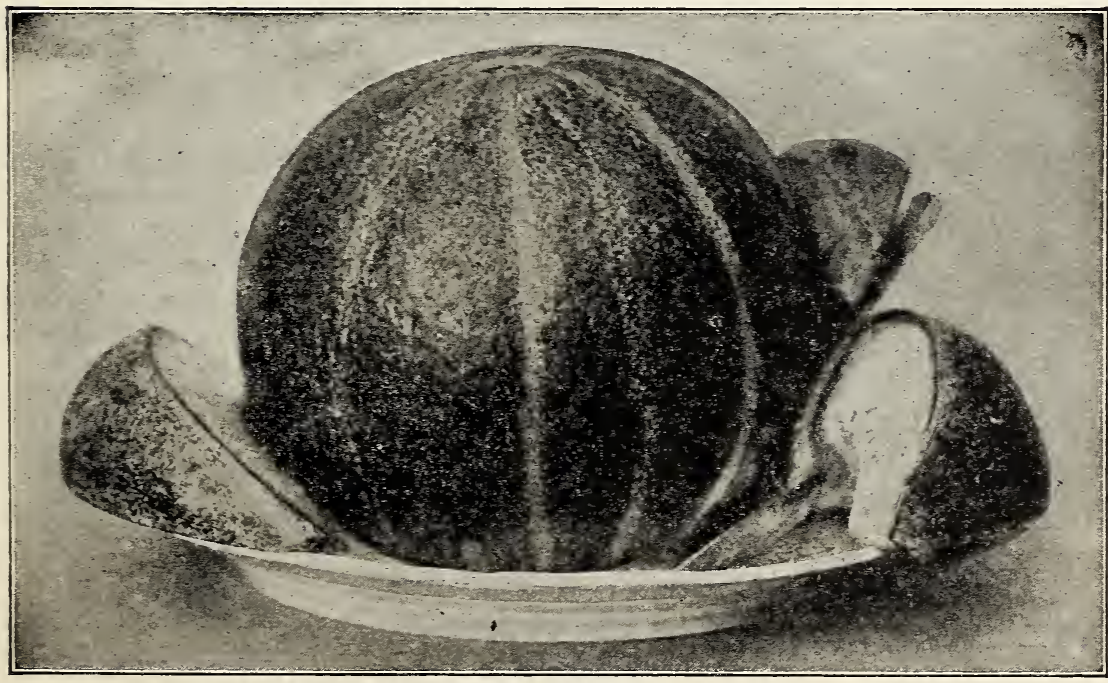

Emerald Gem
* Emerald Gem. This well known variety needs no introduction. Extensively grown for privateand market use. One of the best of the salmon - fleshed sorts. Very sweet. Oz. 15 . $1 / 4$ lb. 35 k. lb. $\$ 1.00,5$ lbs. or more, perlb. 90 .

Extra Early Jenny Lind. Medium size: extra early: green flesh; delicious flavor. 1 Oz. $15 \%, 1 / 4 \mathrm{lb}$. 35 c, lb. $\$ 1.00,5$ lbs or more, per lb. 90 c. 
\ Gold-lined Rocky Ford. A Melon of distinct merit, which should be planted in every garden. Green flesh with golden yellow lining and exceptionally sweet. Oz. $15 \phi, 1 / 4 \mathrm{lb} .40$, lb. $\$ 1.25,5$ lbs. or more, per lb. $\$ 1.10$

Improved Christiana, or Boston Pet. An extra early variety: medium size; thick, luscious, yellow flesh. Oz. $15 \phi$. $1 / 4$ lb. 35 \&, lb. $\$ 1.00,5$ lbs. or more, per lb. $90 \notin$.

Miller's Cream, or Osage. Oblong in shape; skin dark green, thinly netted; flesh salmon color, juicy and sweet. Oz. 15 \&, 1/4 lb. 35 \&, lb. $\$ 1.00,5$ lbs. or more, per lb. $90 \notin$.

$\star$ Milwaukee Market. We consider this an Improved type of Bender's Surprise melon in that it is earlier. little more round, and somewhat better flavor. The fruit is nearly round, medium size, lightly ribbed and fairly netted skin light green, and flesh salmon color and very sweet. Oz. 20\%, $1 / 4$ lb. $50 \&$, lb. $\$ 1.50,5$ lbs.or more, per lb. $\$ 1.35$.

Rocky Ford. A great favorite. Oval, good size, beautifully netted; flesh green, firm and delicious. Unsurpass ed for market and home use. $\mathrm{Oz}$. 15 \&, $1 / 4$ lb. 35 , lb. $\$ 1.00,5$ lbs. or more, per lb. 90 .

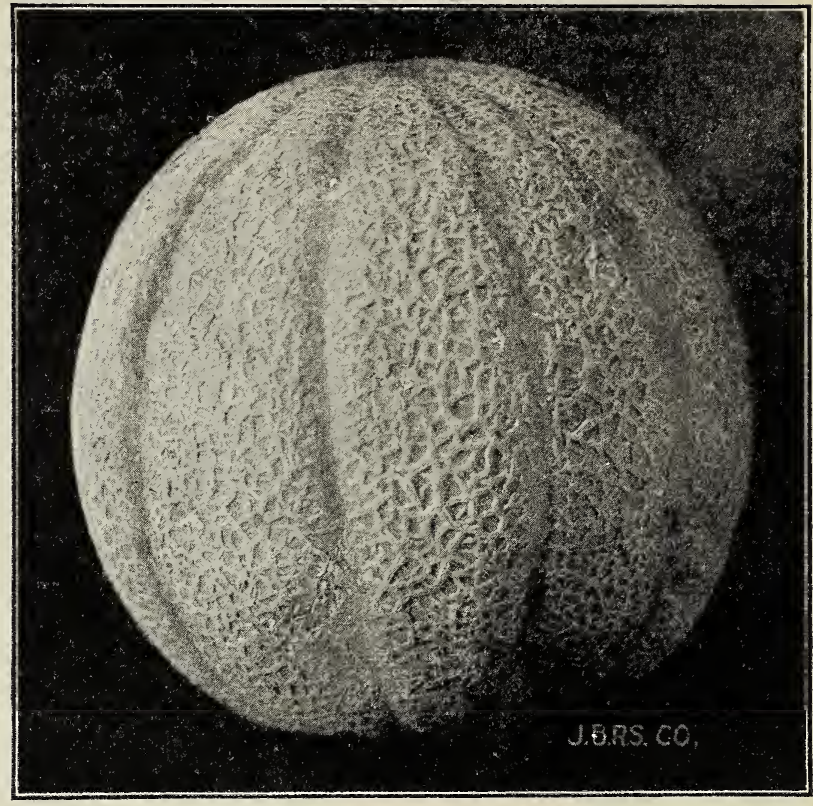

Milwaukee Market

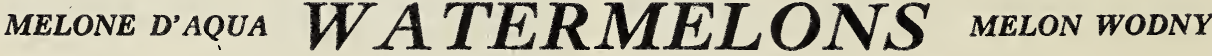

Culture - Watermelons require the same cultural treatment as Muskmelons, except that they should be planted 8 to 10 feet apart, according to varieties. Light, well fertilized soil suits them best. One ounce will plant 40 to 50 hills; 4 pounds for an acre.

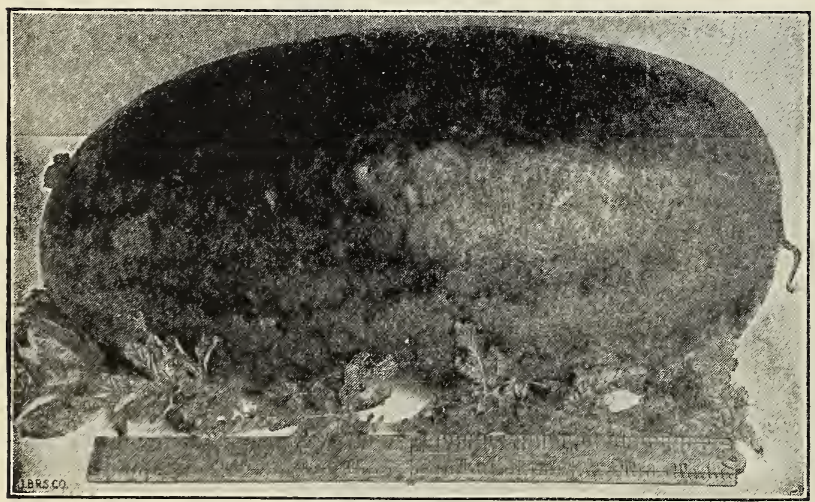

Kleckley Sweets

Please keep a copy of your orders to refer to when goods are received, as sometimes parties think they have ordered items that we don't find on the order and it makes unnecessary correspondence. $\star$ Cole's Early. Extra early and a sure cropper, oblong: striped skin; flesh rich red and of fine texture. Oz. $10 \xi, 1 / 4 \mathrm{lb} .25 \xi, \mathrm{lb} .70 \notin, 5 \mathrm{lbs}$. or more, per lb. $60 \phi$.

Halbert Honey. A long, dark green Melon with a beautiful crimson flesh which will satisfy the most critical. Oz. $10 \xi .1 / 4 \mathrm{lb} .25 \%$. lb. $70 \notin .5$ lbs. or more, per lb. $60 \xi$.

$\star$ Kleckley Sweets. Oblong, dark green, and one of the sweetest in existence. Very thin rind; flesh bright red, crisp and tender. Not a good shipper, but strongly recommended for the home garden and nearby markets. Oz. 10k, 1/4 lb. 25 , lb. $70 \xi_{,} 5 \mathrm{lbs}$. or more, per lb. $60 \xi$.

Peerless, or Ice Cream. Light green; white-seeded flesh scarlet and of fine quality. Oz. 10k, 1/4 lb. $25 \phi$. lb. $70 \xi$. 5 lbs. or more, per lb. $60 \%$.

Red-seeded Citron. Used for preserving. Oz. $10 \xi, 1 / 4$ lb. $25 \phi$, lb. 70 \&. 5 lbs. or more, per lb. $60 \xi$. 


\section{CIPOLLO ONTONSS CEBULA}

Culture - For this important crop a clean, rich piece of land should be selected. As early as possible in the Spring work the soil into a mellow, loose condition, adding plenty of well-rotted barnyard manure or some good commercial fertilizer, pulverizing the soil thoroughly before sowing the seed. Sow in drills 15 inches apart, covering lightly with soil. When the plants are strong enough to handle thin out to about $1 / 2$ inch. Frequent cultivation is necessary to keep down the weeds. The earliest Onions are produced by sowing the seeds in hotbeds in February or March and transplanting to the open ground and also by setting Onion sets. One ounce will sow 100 feet of drill; 4 to 6 pounds per acre.

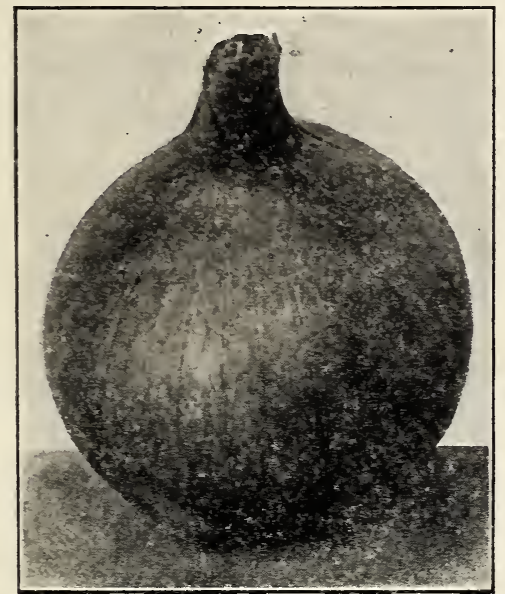

Perfect Yellow Globe Danvers

$\star$ Perfect Yellow Globe Danvers. This has long been a leading variety, and is universally recognized as the best paying Onion for general crop. Nearly round; bright yellow; heavy yielder; splendid keeper. Oz. $20 \mathrm{c}, 1 / 4 \mathrm{lb}$. 60c. lb. $\$ 1.70,5$ lbs. or more, per lb. $\$ 1.50$.

Prizetaker. Large globe shaped variety with white flesh and mild flavor. It is a heavy cropper and fairly good keeper. Quite popular in many sections. Oz. $20 \mathrm{e}, 1 / 4$ lb. $606, \mathrm{lb} . \$ 1.70,5 \mathrm{lbs}$. or more, per lb. $\$ 1.50$.

Silver Skin, or White Portugal. Early maturing flat Onion: silvery-white skin and of mild flavor. The smaller bulbs are used extensively for pickling. Oz. 30 c, $1 / 4$ lb. 80 c, lb. $\$ 2.50,5 \mathrm{lbs}$. or more, per lb. $\$ 2.40$.

Southport Red Globe. Of perfect globe shape; good size, deep red skin; flesh fine-grained and mild. Oz. 25 c, $1 / 4$ lb. $75 c$ c, lb. $\$ 2.00,5$ lbs. or more, per lb. $\$ 1.80$.

$\star$ Southport White Globe. Handsome globeshaped bulbs. Grows to a large size, and has a pure white skin with flesh of a mild flavor. Oz. $35 \mathrm{k}, 1 / 4$ lb. $85 k$, lb. $\$ 3.20,5$ lbs. or more, per lb. $\$ 3.00$.

\section{OCRA OKRA,}

Culture - The green pods of this plant are largely used for soups, stews, etc., and are considered very wholesome and nutritious. Sow in late Spring in drills 2 to 3 feet apart and $1 / 2$ inch deep. Thin the young plants 9 to 12 inches apart.

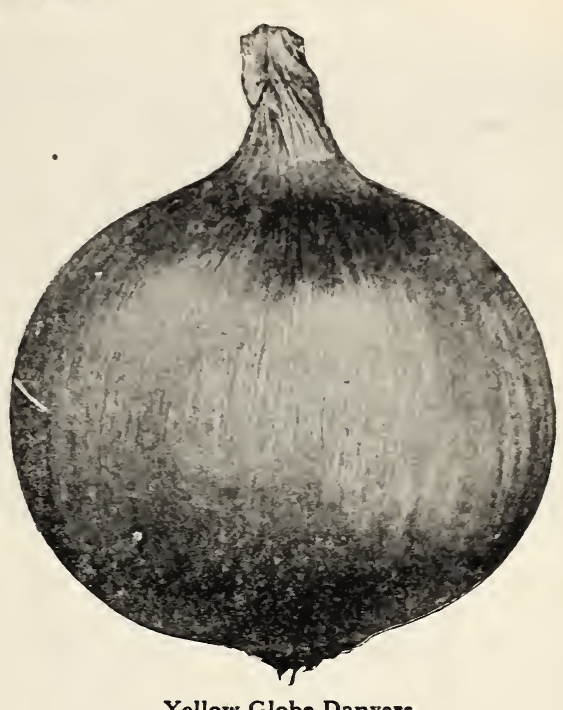

Yellow Globe Danvers

Southport Yellow Globe. Another large, globular Onion, with a rich yellow skin, and flesh of a pleasant flavor. Very popular in all markets. Oz. 20 ć, $1 / 4$ lb. $60 c$, lb. $\$ 1.70,5$ lbs. or more per lb. $\$ 1.50$.

$\star$ Wethersfield Large Red. Extensively grown in some sections. Produces Onions of large size. well flattened and of attractive appearance. The outer skin is dark red, smooth and glossy, while the white flesh is faintly tinged with pink, and rather highly flavored. Oz. $20 \mathrm{c}, 1 / 4 \mathrm{lb}$. 60c. lb. $\$ 1.70,5$ lbs. or more, per lb. $\$ 1.50$.

Yellow Danvers. A round, bright yellow sort; matures early and is a reliable cropper. Oz. 20:, $1 / 4$ lb. 60 c, lb. $\$ 1.50,5$ lbs. or more, per lb. $\$ 1.40$.

$\star$ Yellow Globe Danvers. A favorite variety for Winter use. The bulbs are nearly globe-shaped slightly flattened. Skin light yellow; flesh white, crisp and mild. A splendid keeper. Oz. 20c, $1 / 4$ lb. 60 c, lb. $\$ 1.70,5$ lbs. or more, per lb. $\$ 1.50$.

\section{ONION SETS}

We offer a selection of very choice Onion Sets ( 32 lbs. to the bushel). Plant the sets in row 15 inches apart, and about 2 inches apart in the row. One quart will set about 15 feet of drill; 10 to 12 bushels required for an acre.

Red Onion Sets. Qt. 25 c, 4 qts. 75k, pk. \$1.25, bus. (32 lbs.) $\$ 4.50,5$ bus. or more, per bus. $\$ 4.25$.

White Onion Sets. Qt. 30k, 4 qts. 75c, pk. $\$ 1.40$, bus. (32 lbs.) $\$ 5.00,5$ bus. or more, per bus. $\$ 4.75$.

Yellow Ebenezer or Japanese Onion Sets. Q:. 25 c, 4 qts. 75 c, pk. $\$ 1.25$, bus. (32 lbs.) $\$ 4.50$, 5 bus. or more, per bus. $\$ 4.25$.

Special prices on 10 bushel lots or more. State quantity wanted.

\footnotetext{
May we mail catalogs to your friends that require seeds. Send us their addresses please.
} 


\section{prezzemolo PARSLEY pietruszka}

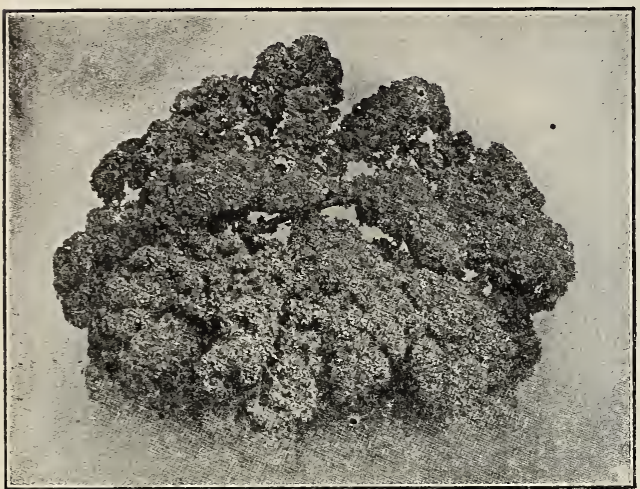

Champion Moss Curled

Culture - The best crops of Parsley are produced in rich, mellow soil. The seed, which germinates very slowly, should be soaked in tepid water for a few hours before using. Sow early in Spring in rows 12 inches apart and $1 / 2$ inch deep. Thin to 1 or 2 inches apart in the row, or transplant. One ounce will sow 150 feet of drill.

$\star$ Champion Moss Curled. Dark green leaves, beautifully curled; very attractive. $1 / 2$ oz. $6 \phi$, oz. 10 \&, $1 / 4$ lb. 25 , lb. 80 \&, 5 lbs. or more, per lb. 70 c.

Double Curled. Fine dwarf variety, with handsomely crimped, deep green leaves. $1 / 2$ oz. $6 \phi$, oz. 10 \&, $1 / 4$ lb. 25 \&, lb. 80 \&, 5 lbs. or more, per lb. $70 \notin$.

Extra Triple Curled. Densely curled and exceedingly useful for garnishing. $1 / 2 \mathrm{oz} .6 \phi, \mathrm{oz} .10 \phi$, $1 / 4$ lb. 25 ф. lb. $80 \phi, 5$ lbs. or more, per lb. $70 \phi$.

\section{PASTINACA PARSTJTS PASTERNAK}

Culture - Parsnip seeds will not germinate in cold, wet soil and should not be sown too early. Sow in drills 18 inches apart, covering with fine soil half an inch deep. Thin out to 2 or 3 inches. Parsnips are improved by frost; they are quite hardy, and may be left in the ground throughout the Winter. One ounce will sow 150 feet of drill; 5 or 6 pounds for an acre. $\star$ Hollow Crown Improved. Smooth, clean and perfectly formed. One of the best for general use. Oz. $15 \phi, 1 / 4$ lb. $40 \phi, \mathrm{lb} . \$ 1.00,5 \mathrm{lbs}$. or more, per lb. 90 .

Improved Guernsey. A good cropper; medium length and of superior quality. Oz. $15 \phi, 1 / 4 \mathrm{lb}$. 40 \&, lb. $\$ 1.00,5$ lbs. or more, per lb. 90 \&.

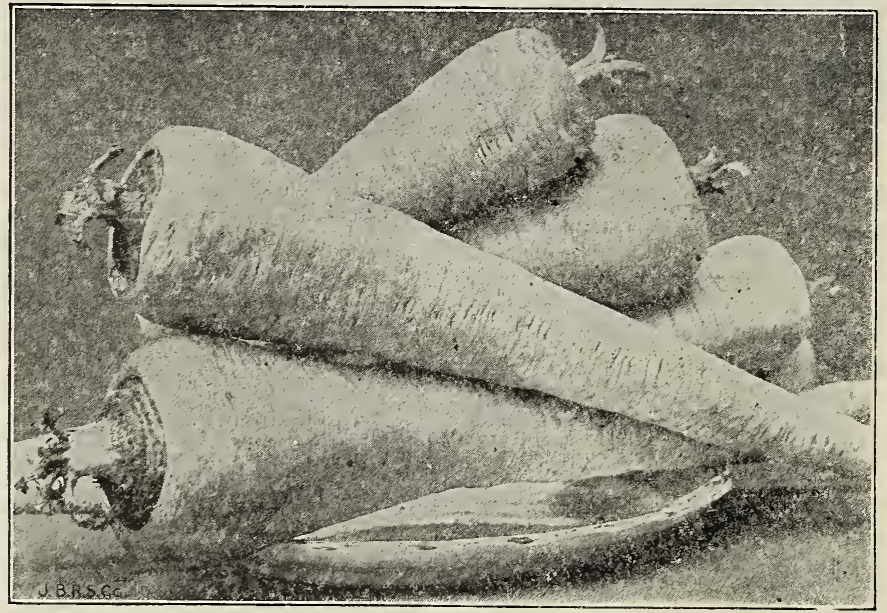

Hollow Crown Improved

\section{PEPERONE}

Culture - Sow in hotbed in March or April and transplant about May 15th in rich, well prepared soil in rows 30 inches apart and 18 inches apart in the row. Seed may be sown in the open ground when all danger from frost is over. Keep the soil well cultivated and free from weeds. One ounce will produce about 1,200 plants.

Chinese Giant. The largest Pepper grown; brilliant scarlet when ripe. The flesh is thick and extremely mild. $1 / 2$ oz. 35 , oz. 60 ', $1 / 4$ lb. $\$ 2.25$, lb. $\$ 8.00$.

$\star \quad$ Large Bell, or Bull Nose. An old and popular variety and much used for stuffing when green.

\section{PIEPRZ}

Ripens early, the flesh being thick and of hot flavor. $1 / 2$ oz. 25 , oz. $40 \phi, 1 / 4$ lb. $\$ 1.25$, lb. $\$ 4.50$.

$\star$ Harris' Extra Early. The earliest pepper known. Plants very uniform in growth. Dwarf, compact and very prolific. Fruit pendent, mild and sweet similar to Bull Nose in form. $1 / 2$ oz. $30 \%$ oz. 50 é, $1 / 4$ lb. $\$ 1.50, \mathrm{lb}$. $\$ 5.00$.

Ruby King. Of the large-fruited Peppers this is probably the most popular. It is quite productive, and the flesh is thick, sweet and mild. The ruby red fruits make a very handsome appearance. $1 / 2$ oz. 25 , oz. $40 \phi, 1 / 4$ lb. $\$ 1.25$, lb. $\$ 4.50$. 


\section{PIsello GARDEN PEAS groch}

Half bushel at bushel rate

Culture - Peas should be sown as early as possible to mature before the hot Summer weather sets in, as they do not amount to much in hot weather. To secure an extra early crop sow the smooth varieties as early in the Spring as the weather and the condition of the soil will permit. The wrinkled class are not so hardy and should be planted a few days later. Sow the seed thickly 2 to 3 inches deep in single or double rows 3 to 4 feet apart. The tall-growing kinds require brush or other support. One quart will plant 100 feet of drill; $11 / 2$ bushels to the acre. Wrinkled varieties are indicated by a dagger $(\dagger)$.

\section{First Early Varieties}

Alaska. A first-early round variety, producing well-filled, medium-sized, dark green pods; quality good. The dry seed has a bluish tinge and is slightly pitted. Height $21 / 2$ feet. $\mathrm{Pt}$. $25 \mathrm{c}$, qt. 45 k, 4 qts. $\$ 1.30$, pk. $\$ 2.40$, bus. $\$ 9.00$.

Ameer, or Large Podded Alaska. Of the Alaska type, but the pods are larger and more plentiful. Two or three days later in maturing. Height 3 feet. Pt. 30 \&, qt. 50 \&, 4 qts. $\$ 1.50$, pk. $\$ 2.60$, bus. $\$ 10.00$.

tAmerican Wonder. This is an extra early dwarf wrinkled Pea of all-round excellence. The pods are about $21 / 2$ inches long and

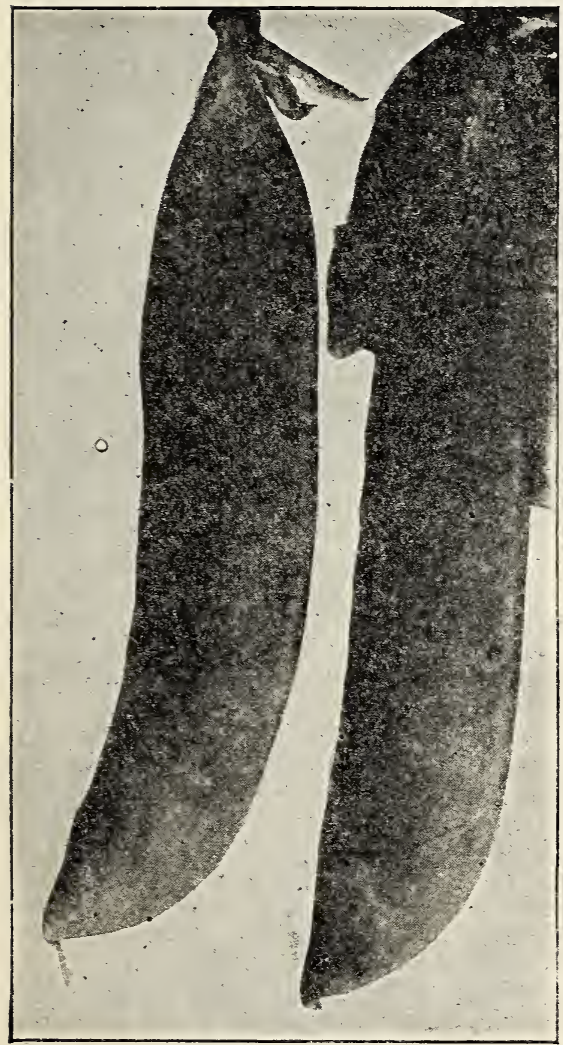

Gradus, or Prosperity

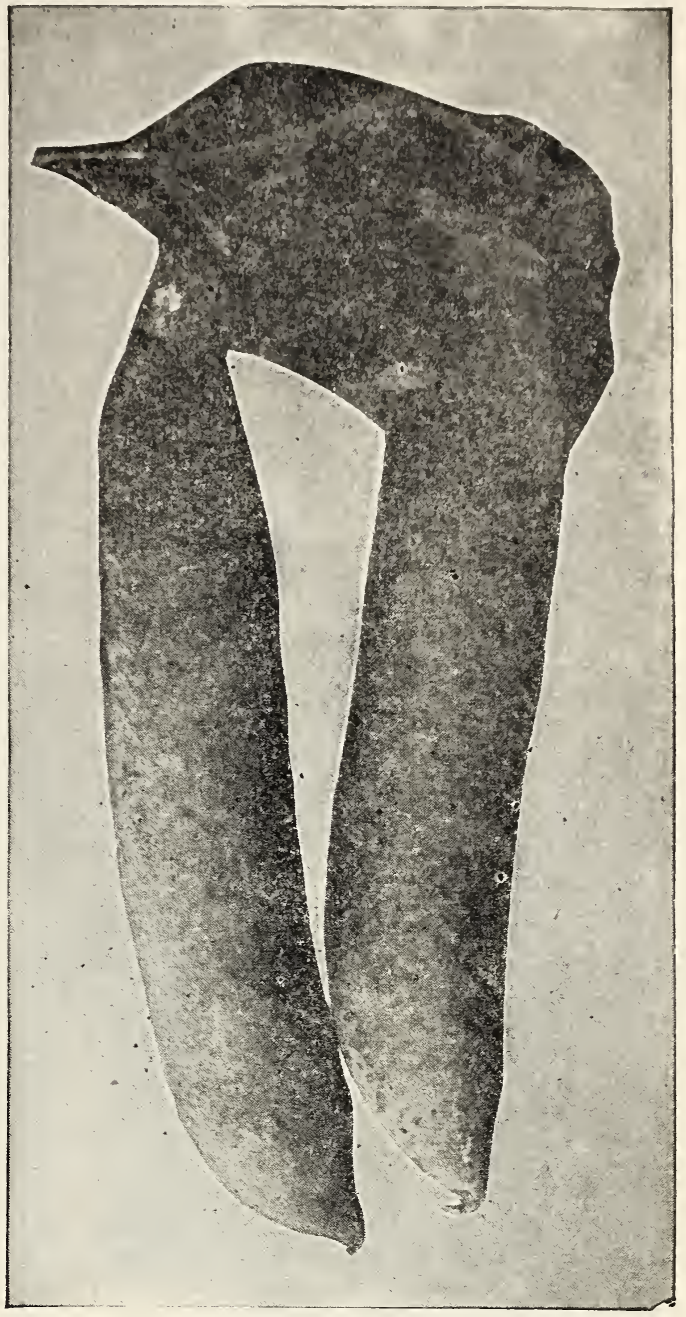

Top O' The Morn

filled to the end with peas of the first class quality. Height about 15 inches. Pt. 30 , qt. 50 \&, 4 qts. $\$ 1.50$, pk. $\$ 260$. bus. $\$ 10.00$.

East Hartford Extra Early. This extra early smooth Pea is quite popular for its earliness, as it can be sown earlier than most varieties. The pods are not large, but the vines are prolific bearers and the peas are of good quality. Height $21 / \mathrm{q}$ feet. Pt. $25 \phi$. qt. $45 \phi .4$ qts. $\$ 1.30$, pk. $\$ 2.40$, bus. $\$ 9.00$.

†Extra Early Premium Gem. A dwarf wrinkled variety of excellent flavor, maturing a few days later than American Wonder. Very productive; pods $21 / 2$ to 3 inches long, round and well filled. Height 15 to 18 inches. Pt. 25 \&, qt. 45 c, 4 qts. $\$ 1.30$, pk. $\$ 2.40$, bus. $\$ 9.00$.

$\star$ †Top O' The Morn. A new extra early variety of excellent quality, dwarf, dark green compact vine of Sutton Excelsior type and very prolific. Pods long dark green color and well filled, one of the first to mature. Height 18 inches. Pt. 35 , qt. 60 c, 4 qts. $\$ 2.00$, pk. $\$ 3.60$, bus. $\$ 14.00$. 


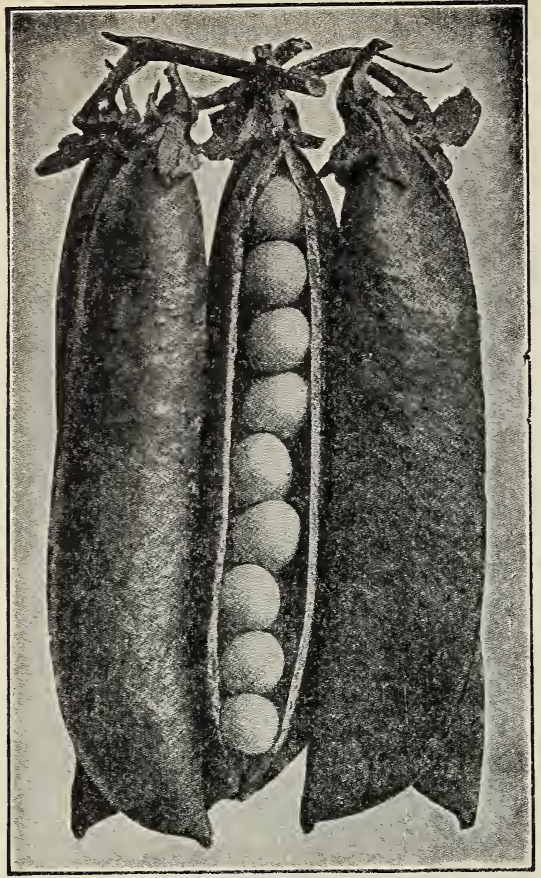

Sutton's Excelsior

* tGradus, or Prosperity. One of the earliest and most popular of all the large-podded wrinkled peas. When grown under favorable conditions the vines are vigorous and healthy, yielding uniformly large pods well filled with handsome, plump peas of delicious quality. The seed is large, wrinkled, cream color tinged

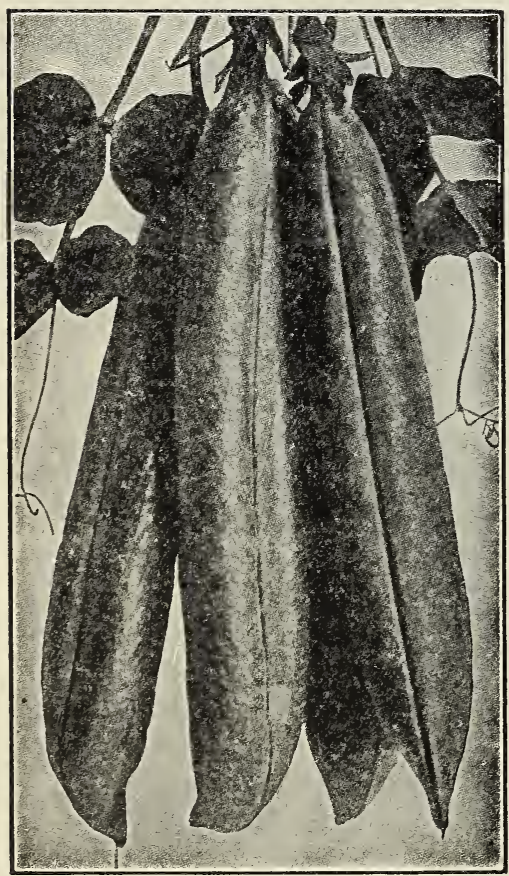

Hundredfold with green. Height $2 \frac{1}{2}$ feet. For best results the vines should be brushed. Pt. 35 \&, qt. 55 \&. 4 qts. $\$ 1.60$, pk. $\$ 2.90$, bus. $\$ 11.00$.

* Hundredfold. Considered by many the best type of Laxtonian. The sturdy vines grow very vigorous with large dark green leaves and are very productive of dark green, large podded peas of finest quality. Height 18 inches. $\mathrm{Pt}$. 35 \&. qt. 60 \&. 4 qts. $\$ 1.80$, pk. $\$ 3.10$, bus. $\$ 12.00$.

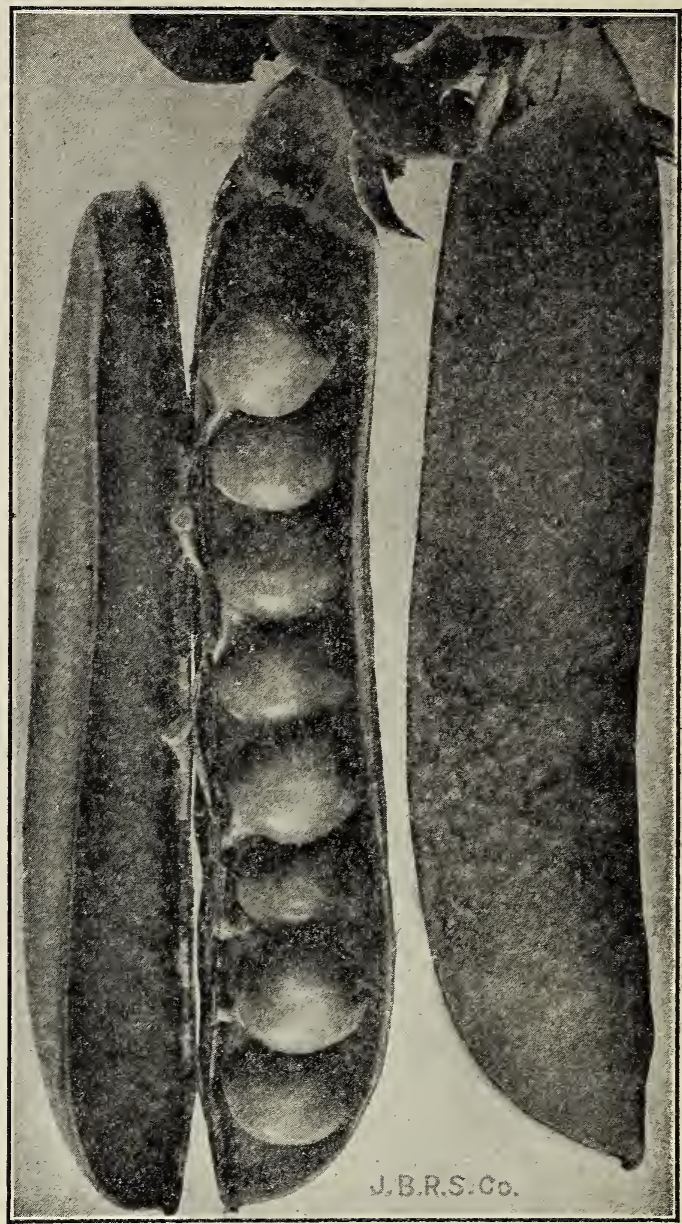

Incomparable

†Laxtonian. (Peter Pan) A grand dwarf wrinkled Pea, maturing very early in the season. The robust vines produce a liberal supply of large sized pods, which are well filled with peas of the finest quality. Height 20 inches. Pt. 35 $\mathrm{p}$, qt. 60 \&. 4 qts. $\$ 1.80$, pk. $\$ 3.10$, bus. $\$ 12.00$.

†Little Marvel. This variety has become quite popular. The vines are thickly set with pods averaging $21 / 2$ inches in length and filled with deep green peas of the choicest quality. Matures about same time as American Wonder. Height 18 inches. Pt. 35 , qt. 55 \&. 4 qts. $\$ 1.60$, pk. $\$ 2.90$, bus. $\$ 11.00$.

†Nott's Excelsior. Of compact, dwarf growth and a heavy cropper. The pods are good size and closely filled with peas of unusually sweet flavor. Height 15 inches. Pt. 30k. qt. 50 k. 4 qts. $\$ 1.50$, pk. $\$ 2.60$, bus. $\$ 10.00$.

* TSutton's Excelsior. A handsome dwarf variety which comes into bearing very early. Extensively grown by market gardeners, and is considered by many the best all around Pea for the home garden. The vines are stout and hardy 


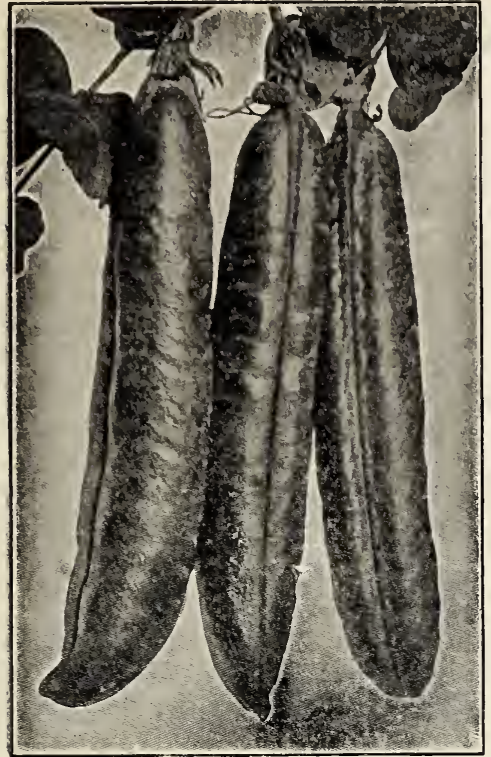

Thomas Laxton

GARDEN PEAS-FIRST EARLY VARIETIES-

Continued

and produce, in great abundance, large, straight. pale green pods which are crowded with peas of exquisite flavor. Seed green and wrinkled. Height about 18 inches. Pt. 35k, qt. 55 \&. 4 qts. $\$ 1.60$. pk. $\$ 2.90$, bus. $\$ 11.00$.

$\star$ †Thomas Laxton. In some quarters this Pea is claimed to possess greater merit than the famous Gradus, which in many characteristics it closely resembles. The pods are not quite as large, but they are more numerous and better filled with peas of extra fine quality. Height about 3 feet. Pt. 35 , qt. 55 c. 4 qts. $\$ 1.60$, pk. $\$ 2.90$, bus. $\$ 11.00$.

$\star$ †World's Record. An improved type of Gradus which it greatly resembles both as to growth of vine and size, shape and color of pods. fully as early and good yielder of excellent quality. This variety is highly recommended. Height $21 / 2$ feet. Pt. 35 \&. qt. 55 \&. 4 qts. $\$ 1.60$, pk. $\$ 2.90$. bus. $\$ 11.00$.

\section{Second Early Varieties}

Bliss's Abundance. A popular variety bearing a liberal crop of pods well filled with peas of splendid flavor. Height 2 feet. $\mathrm{Pt}$. 30k. qt. 50 \&. 4 qts. $\$ 1.50$, pk. $\$ 2.60$, bus. $\$ 10.00$.

* IIncomparable. One of the finest and most productive main crop Peas. Vine and foliage very sturdy, heavy dark green. Pods very large, broad dark green about 5 inches long, nearly straight and well filled. $\mathrm{Pt}$. $35 \xi$. qt. $60 \xi .4$ qts. $\$ 2.00$, pk. $\$ 3.60$, bus. $\$ 14.00$.

\section{Medium and Late Varieties}

fDwarf Telephone, or Carter's Daisy. The short, stocky vines bear a generous crop of long pods filled with large, light green wrinkled peas, tender and sweet. Height about 15 inches. Pt. 35 \&. qt. 55 \&. 4 qts. $\$ 1.60$, pk. $\$ 2.90$, bus. $\$ 11.00$.
Allan's Improved Telephone or Admiral Dewey. This variety is a leader for a late large podded Pea and highly ecommended for a late main crop. The pods are long and color, and the peas are of unsurpassed quality. Bliss's Everbearing. The vigorous branching vines yield ods of medium size, filled with large peas of fine flavor. Height about 2 feet. Pt. 30 \&. qt. 50 \&. 4 qts. $\$ 1.50$, pk. $\$ 2.60$. us. $\$ 10.00$. ath valed with fair sized pods filled with peas of fine Improved Stratagem. A heavy cropper, the stout, branching vines being covered with large pods containing wrinkled peas of excellent quality. Height 2 feet. Pt. $35 \xi$, qt. 55 k. 4 qts. 60 . pk. $\$ 2.90$, bus. $\$ 11.00$.

Content. Of Telephone type, heavy dark green vine and foliage, pods about 5 inches long. broad and numerous and the peas are of best quality. Height $31 / 2$ feet. $\mathrm{Pt} .35 \mathrm{k}$. qt. 55 \&. 4 qts. $\$ 1.60$, pk. $\$ 2.90$, bus. $\$ 11.00$.

CANADA FIELD PEAS. See page 38.

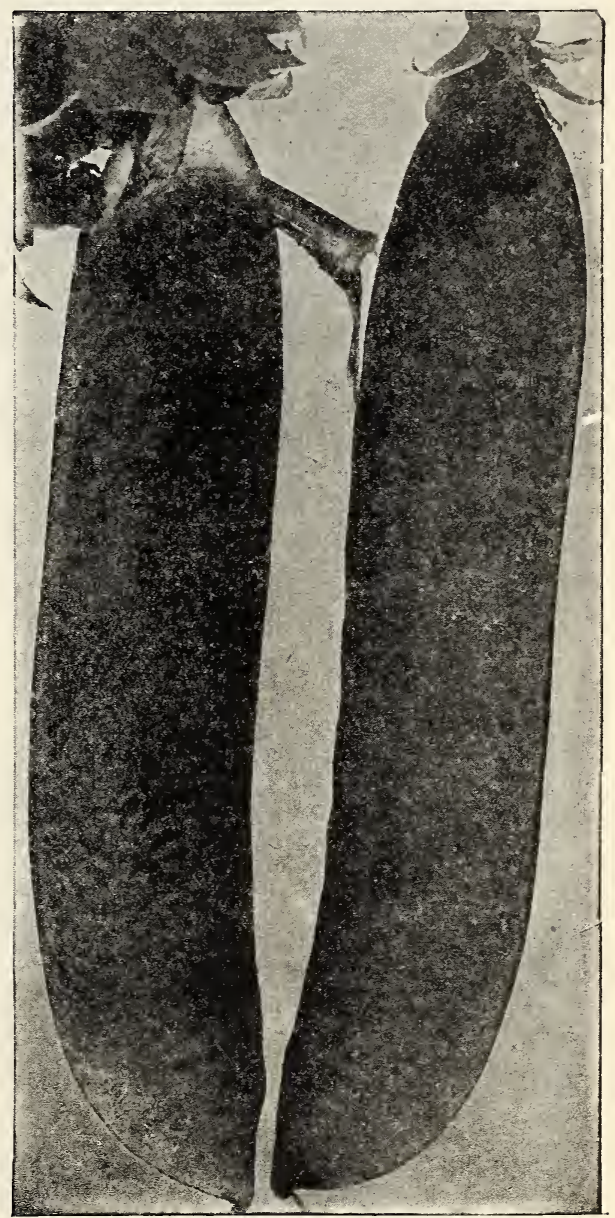

Allan's Improved Telephone 


\section{ZUCCA PUMPKIN BANIA}

Culture - Best results are obtained when planted in rich soil. When the ground has become warm in May plant the seeds in hills, 8 to 10 feet apart each way, as the vines, being rank growers, require ample: space in which to spread. Thin out the seedlings when well above the surface, leaving 3 or 4 of the strongest in each hill. Pumpkins are often grown in the cornfield, 3 or 4 seeds being dropped in every third or fourth hill; plant at the same time as the Corn. One ounce will plant 15 to 20 hills; 3 pounds for an acre.

Connecticut Field. A large oblong yellow variety flattened at the ends, grown chiefly for feeding stock. Oz. $10 \phi, 1 / 4 \mathrm{lb} .25 \xi, \mathrm{lb} .60 \%, 5 \mathrm{lbs}$. or more, per lb. 50 c.

$\star$ Small Yellow Sugar. Prolific, fine-grained and sweet. One of the best pie Pumpkins. Oz.

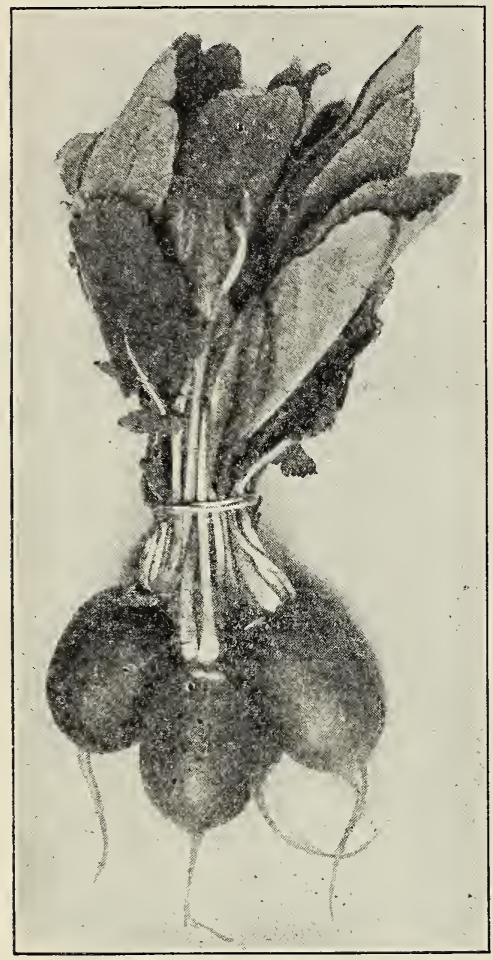

Early Scarlet Globe

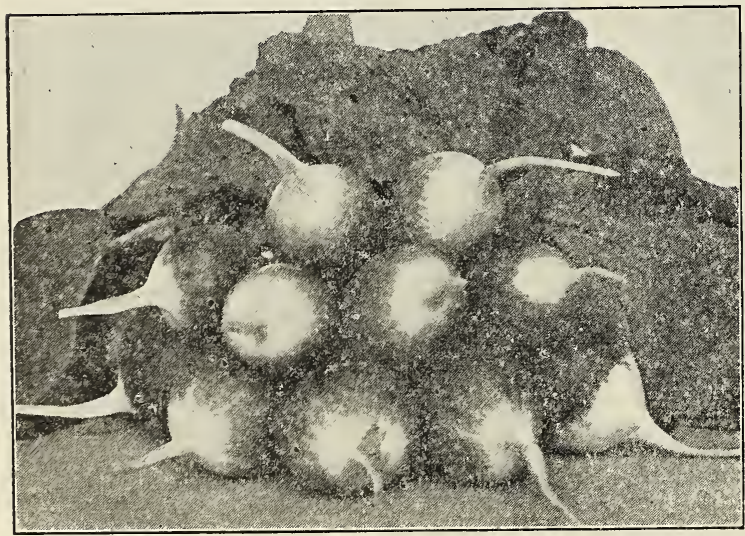

Extra Early Sparkler
10 \&, $1 / 4$ lb. 25 \&, lb. 75 \&, 5 lbs. or more, per lb. 65 \&.

Mammoth Potiron, or King of Mammoths. Fruits grow to an enormous size. The skin is salmon orange, and the very thick, tender, pale. yellow flesh is much used for pies and stock feeding. Oz. 15 c, $1 / 4$ lb. 35 c, lb. $\$ 1.25,5$ lbs. or more, per lb. $\$ 1.10$.

Winter Luxury. A first-grade pie Pumpkin. Round, golden russet skin, finely netted; flesh deep yellow and very sweet. A splendid keeper. Oz. $10 \notin, 1 / 4$ lb. $25 \phi$, lb. $80 \notin, 5$ lbs. or more, per lb. $75 \phi$.

\section{RAVANELLO RADISH RZODKIEW}

Culture - Radish grows quickly and can be sown between rows of some slow growing crop and be out of the way when the late crop comes on, thus saving space. For extra early use sow in the greenhouse or hotbed in January or February. Garden culture may commence as soon as the frost has disappeared, and for a continuous supply sow at intervals of two weeks until September. Sow in rows 8 to 10 inches apart, cover lightly with fine soil, and thin out to 1 or 2 inches. One ounce will sow 100 feet of drill 8 to $10 \mathrm{lbs}$. for an acre.

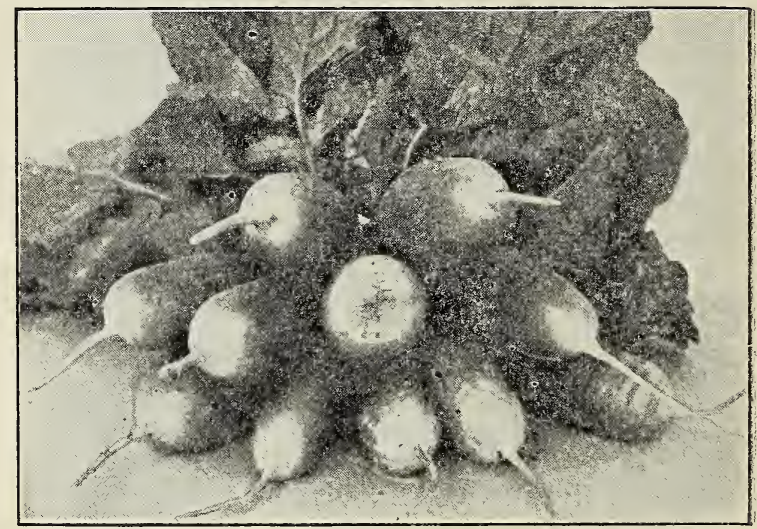

Early French Breakfast

$\star$ Early Deep Scarlet Turnip. A wellknown, quick growing Radish; crisp and mild; extensively grown for market. Oz. $10 \notin, 1 / 4$ lb. $25 \phi, l b .75 \phi, 5$ lbs. or more, per lb. 65 c.

Early White Turnip. When bunched this early round snowy white Radish makes a very attractive appearance. Oz. $10 \AA, 1 / 4$ lb. 25 \&, lb. 75 \&, 5 lbs. or more, per lb. 65 \&.

$\star$ Extra Early Sparkler. Round with crimson top and white tip. In every repect a satisfactory sort; tender and crisp. Oz. $10 \phi, 1 / 4$ lb. $30 \notin, \mathrm{lb} .80 \phi, 5$ lbs. or more, per lb. $70 \notin$.

$\star$ Early French Breakfast. Oblong shaped, scarlet with white tip. Good for forcing or outdoor culture. Oz. $10 \phi$. $1 / 4$ lb. $30 \phi$, lb. $80 \phi, 5$ lbs. or more, per lb. 70 c. 


\section{RADISH-Continued}

* Early Scarlet Globe. A fine variety for forcing or field culture; bright scarlet color: flesh white and crisp. Oz. 10 k. 1/4 lb. 30 k. lb. 80 k. 5 lbs. or more, per lb. $70 c$.

Early Scarlet Turnip. Highly esteemed for its beautiful color and fine quality. Oz. $10 \mathrm{k}, 1 / 4 \mathrm{lt}$. 25 c, lb. 75 c. 5 lbs. or more, per lb. 65 c.

Early Scarlet Turnip, White Tip. A bright scarlet, white tipped Radish of delicate flavor. Oz.

\section{RABARBARO RHUBARB}

Culture - Sow early in Spring in shallow drills 12 to 15 inches apart and thin out to about 10 inches apart in the rows. In the Fall or following Spring transplant in very rich garden soil 3 feet apart each way. One ounce will produce about 700 plants.

\section{SPINACE SPINACH}

10 k. $1 / 4$ lb. 25 c. lb. 75 c. 5 lbs. or more, per lb. 65 غ.

Round Black Spanish Winter. A popular winter variety; globe-shaped and good quality. $\mathrm{Oz}$. 10 k. $1 / 4$ lb. 30 k. lb. 80 c. 5 lbs. or more, per lb. 70 c.

White Vienna, or Lady Finger. An early-maturing, long pure white Radish, of mild and pleasant flavor. Oz. 10 c, $1 / 4$ lb. 30 k, lb. 80 k. 5 lbs. or more, per lb. 70 c.

\section{(Pie Plant) RUbarbarum}

Large Victoria. The most popular variety grown, and in general use by market gardeners. Yields immense crops; stalks large and of the best quality. $1 / 2$ oz. 10 c, oz. 15 c, $1 / 4$ lb. 55 c, lb. $\$ 2.00$

Culture - Spinach is best developed when grown in well-enriched soil. It is of easy culture, and by successional sowing a supply may be secured throughout the season. For early Spring use sow the seed in September in drills 12 to 15 inches apart.

Protect the bed during the Winter by covering with straw or hay, removing it when the plants start growth in the Spring. For late Spring, Summer and Fall use, begin sowing the seed as early in Spring as possible and sow at intervals of two or three weeks, up to Aug. 1st., either in drills or broadcast. One ounce will plant 100 feet of drill: 10 to 12 pounds for an acre.

Curly Savoy, or Bloomsdale. A valuable, hardy variety for Spring and Fall sowing but will run to seed quickly in hot weather. Sown extensively in Fall to carry through the Winter. The leaves are dark green, thick, wrinkled and of good flavor. Oz. 10c. $1 / 4$ lb. 25 c, lb. 50 c. 5 lbs. or more, per lb. $40 c$.

$\star$ Early Giant. Thick-leaved. Most useful for early Spring crop. Ready for use in about 30 days from sowing. The leaves are large, thick, pointed, rather light green colored and very tender. Inclined to seed quickly in hot weather.

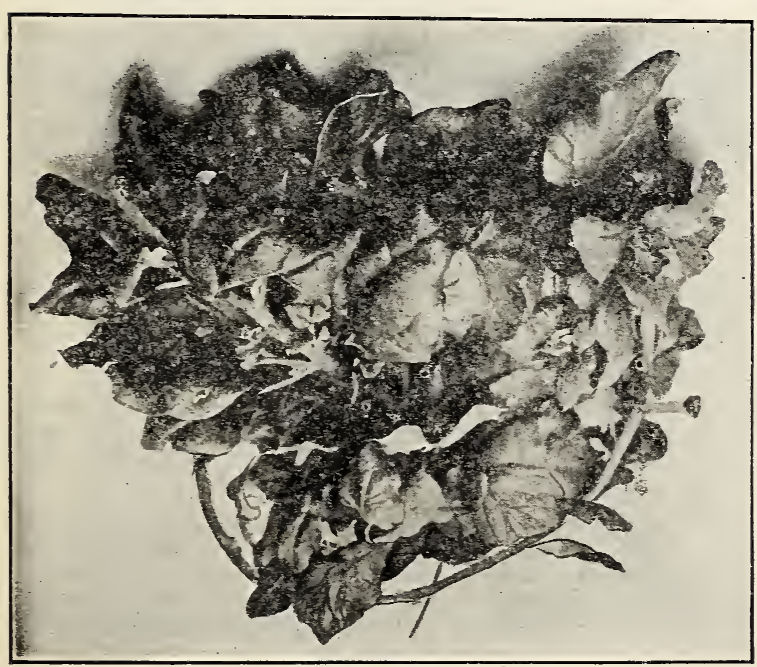

New Zealand

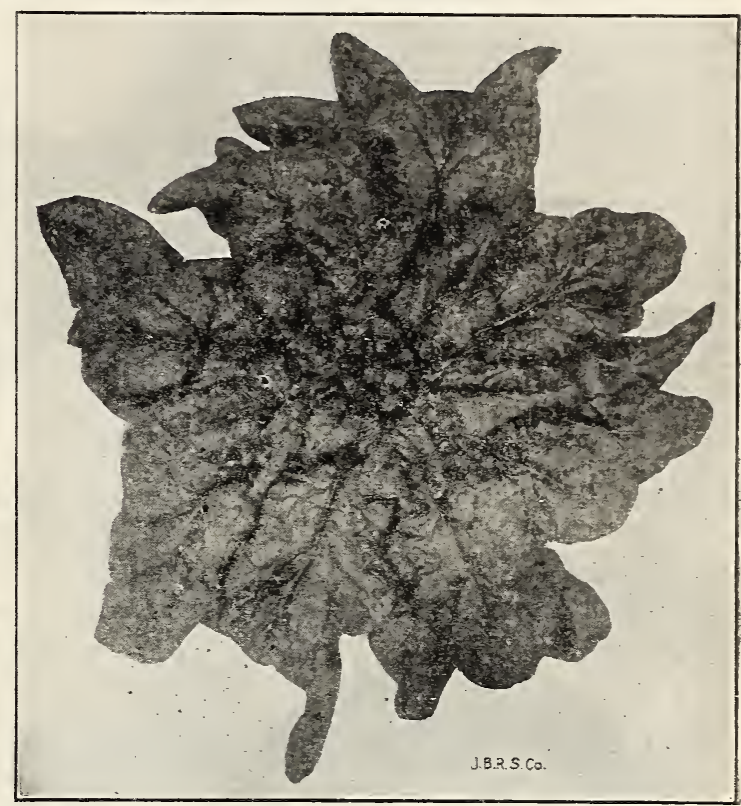

King of Denmark

Oz. 10 ć, 1/4 lb. 20 ć, lb. 40 c. 5 lbs. or more per lb. $30 \mathrm{c}$.

$\star \quad$ King of Denmark. A vigorous spreading plant. Crumpled, large dark green, round leaves and does not run to seed quickly. While this variety is not quite as early as some of the other varieties, we consider it one of the best for general use. Oz. 10ć, $1 / 4$ lb. 25 ć, lb. 50 ć, 5 lbs. or more, per lb. $40 \mathrm{c}$.

$\star$ Princess Juliana. A thoroughbred type of long standing spinach. Uniform in type and wonderfully attractive in appearance. The dark green crumpled leaves form a very dense compact rosette, slow to run to seed which makes it a valuable spinach for both market and private use. Oz. $10 \mathrm{c}, 1 / 4 \mathrm{lb}$. 25 c. lb. 50 c, 5 lbs. or more, per lb. 40 c.

$\star$ New Zealand. This is a notable variety, distinctly different from ordinary Spinach. It flourishes in almost any soil, is of strong growth, resists heat and makes a delicious green throughout the Summer. $\mathrm{lt}$ is of a branching nature and continues 


\section{SPINACH-Continued}

to grow after cutting thus producing a supply through the season. It is a hard shelled seed and often hard to germinate. Should be soaked in water several hours before planting. Oz. $15 \phi, 1 / 4 \mathrm{lb} .25 \phi, \mathrm{lb} .60 \phi, 5 \mathrm{lbs}$. or more, per lb. $50 \phi$.
Victoria. A good Spring and Fall sort for market or home use. Quite similar to Early Giant. Thick-leaved. Oz. $10 \notin, 1 / 4$ lb. 20 , lb. 40 , 5 lbs. or more, per lb. $30 \phi$.

\section{SASSEFRICA SALSIFY, OT OYSTER PLANT JARZY OSTRYGa}

Culture - Sow early in Spring in light, deep soil in drills 12 inches apart, and cover to a depth of 1 inch. Thin the young plants to 2 or 3 inches. The roots will be ready for use in October, when a supply can be stored for Winter use. Salsify is hardy and can be left in the ground till Spring. One ounce will sow 50 feet of drill.

Mammoth Sandwich Island. Grows to an extra large size. The roots are quite smooth, very mild and delicate in flavor. $1 / 2$ oz. $10 \xi$, oz. $15 \xi$. $1 / 4$ lb. 55 , lb. $\$ 1.75,5$ lbs. or more, per lb. $\$ 1.50$.

\section{ZUCCA SQUASH MIERURZ}

Culture - Warm and highly manured soil is required for the successful culture of Squash. The Summer kinds, nearly all of which are of bush growth, should be planted in hills 4 feet apart each way, while the Winter or running varieties should be planted in hills 8 to 10 feet apart. When thinning out leave three or four of the sturdiest plants in each hill. One ounce of seed to 25 hills for Summer varieties; 2 ounces to the same number of hills for Winter sorts. Winter Squashes are frequently grown in cornfields in the same manner as Pumpkins.

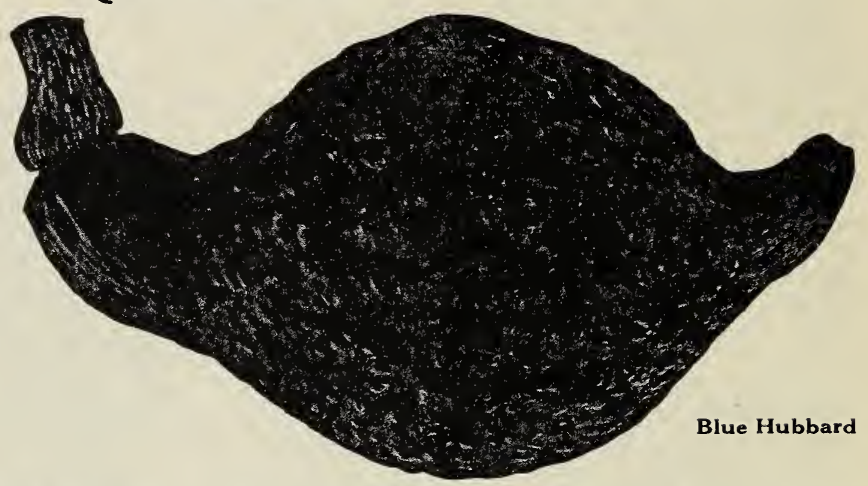

Blue Hubbard. A large bluish-gray skinned Hubbard Squash with a very hard shell which makes it an excellent keeper, golden orange colored flesh, dry and delicious flavor. Oz. 15 \&, $1 / 4$ lb. 40 \&, lb. $\$ 1.10,5$ lbs. or more, per lb. $\$ 1.00$.

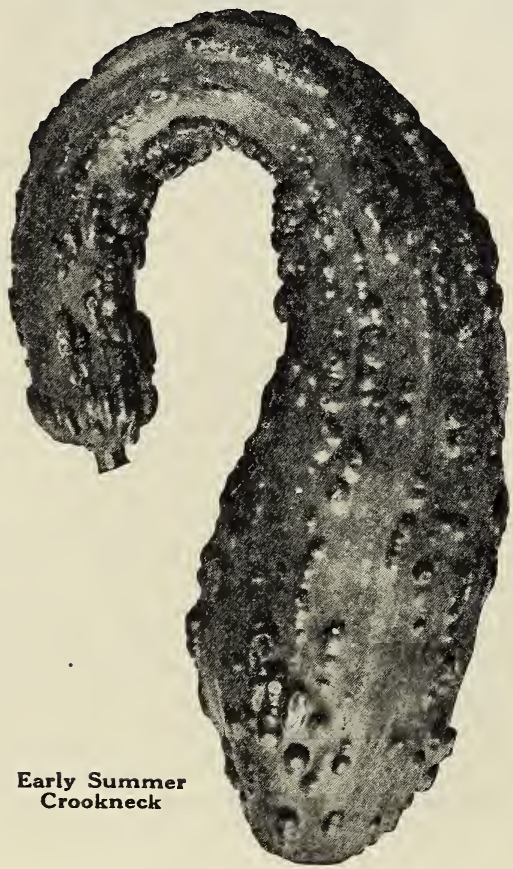

Boston Marrow. A good-sized Fall or Winter variety and a leader in many markets. Skin bright orange; flesh rich orange and of fine quality. Oz. $10 \phi, 1 / 4$ lb. $25 \phi, \mathrm{lb} .80 \phi, 5 \mathrm{lbs}$. or more, per lb. $75 \phi$.

Chicago Warted Hubbard. An ideal Winter Squash of the Hubbard strain. Dark green, warted skin; flesh orange yellow, dry and sweet. Oz. $15 \notin, 1 / 4$ lb. $40 \notin, \mathrm{lb}$. $\$ 1.10,5$ lbs. or more, per lb. $\$ 1.00$.

* Delicious. Unexcelled as a Fall or Winter Squash for table use. Resembles the Hubbard in size and shape. Color of skin varies from light to dark green. Flesh dark orange and, as the name suggests, of delicious flavor. Oz. $15 \%, 1 / 4$ lb. $40 \&, \mathrm{lb}$. $\$ 1.10,5 \mathrm{lbs}$. or more, per lb. $\$ 1.00$.

$\star$ Early Summer Crookneck. One of the best and most popular of Summer Squashes. Early and productive. Fruits large, heavily warted and of golden yellow color; flesh solid and agreeable to the taste. Oz. $15 \phi, 1 / 4 \mathrm{lb} .35 \phi, \mathrm{lb}$. $\$ 1.00,5 \mathrm{lbs}$. or more, per lb. $90 \%$.

Giant Summer Crookneck. Similar to the Early Summer Crookneck, but attain a much larger size. Oz. 15 , $1 / 4 \mathrm{lb}$. 40 , lb. $\$ 1.10,5 \mathrm{lbs}$. or more, per lb. $\$ 1.00$.

Golden Hubbard. A valuable Winter variety with a deep orange-yellow rough skin and fine grained, sweet flesh. Oz. $15 \phi, 1 / 4 \mathrm{lb} .40 \phi, \mathrm{lb}$. $\$ 1.10,5$ lbs. or more, per lb. $\$ 1.00$.

$\star$ Improved Hubbard. The tough, dark-green skin of this well-known Winter Squash makes it a splendid keeper and shipper. Flesh rich yellow or orange and when cooked is very dry, tender and sweet. Oz. $15 \phi, 1 / 4 \mathrm{lb}$. 40 , l lb. $\$ 1.10,5 \mathrm{lbs}$. or more, per lb. $\$ 1.00$. 


\section{POMO D'ORO TOMMATO POMIDOR}

Culture - To furnish desirable plants for setting out as soon as the weather becomes sufficiently warm, the seed should be sown in February or March in a hotbed, coldframe or a box kept in a warm place. When the plants are about 2 inches high thin or transplant to stand 4 inches apart each way, or prick out in pots or flats; this is necessary to secure compact, stocky plants. Harden the plants by exposing them to the weather when warm enough not to injure the plants. About the 10th of May, or as soon after as all indications of frost have vanished, the plants may be transferred to the open ground, setting 3 to 4 feet each way. They should be frequently cultivated. The Tomatoes ripen earlier and are improved in quality when the vines are pruned to one or two stems and trained to stakes or trellises. Plants for late Summer or Fall crops can be obtained by sowing seed in a small bed in May or the first week in June. To avoid weak, spindly growth, thin out to about 5 inches apart. One ounce of seed will produce about 1,500 plants.

- Bonny Best. A very popular variety with many market gardeners, and excellent for home use. It ripens very evenly and nearly as early as the Earliana and practically free from cracks. Its color is bright scarlet and very attractive which makes it an excellent market variety. $1 / 2 \mathrm{oz}$. 15 c, oz. 25 c, $1 / 4$ lb. 80 c, lb. $\$ 3.00$.

Chalk's Early Jewel. Unrivaled among the earlies. A continuous bearer of large, smooth, bright red fruits of finest quality. $1 / 2 \mathrm{oz} .15 \mathrm{k}, \mathrm{oz}$. 25 , $1 / 4$ lb. 80 c, lb. $\$ 3.00$.

Dwarf Champion. Of dwarf and compact growth. The purplish pink fruits are of medium size, round,

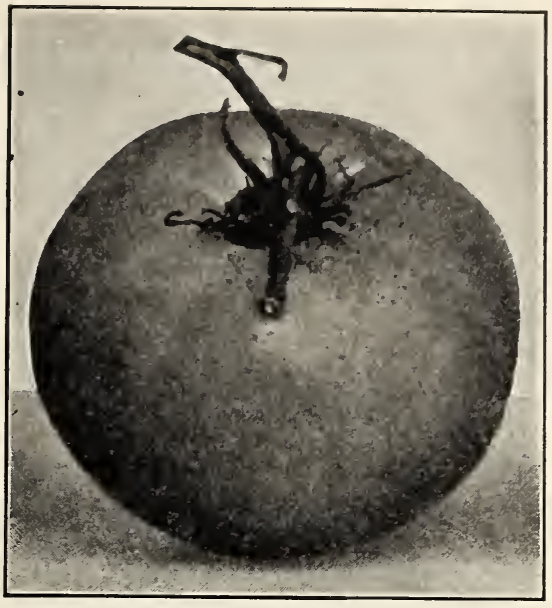

John Baer

smooth and solid. $1 / 2$ oz. 15 , oz. 30 \&, $1 / 4 \mathrm{lb} . \$ 1.00$. lb. $\$ 3.75$.

$\star$ John Baer. A fine type of early tomato. A continual bearer of large bright red solid tomatoes desirable for both home and market garden. $1 / 2$ oz. 15 c, oz. 25 ধ, $1 / 4$ lb. 80 ধ, lb. $\$ 3.00$.

Golden Queen. A very beautiful bright yellow Tomato of large size. Smooth and ripens early. Good for slicing or preserving. $1 / 2 \mathrm{oz} .20 \phi$, oz. 30 \&. $1 / 4$ lb. $\$ 1.00$, lb. $\$ 3.75$.

Henderson's Ponderosa. The largest and heaviest Tomato grown. Purplish crimson in color. The fruit is very solid with few seeds and practically free from acid. $1 / 2$ oz. 20 c, oz. 30 c, $1 / 4 \mathrm{lb}$. $\$ 1.00, \mathrm{lb}$. $\$ 3.75$.

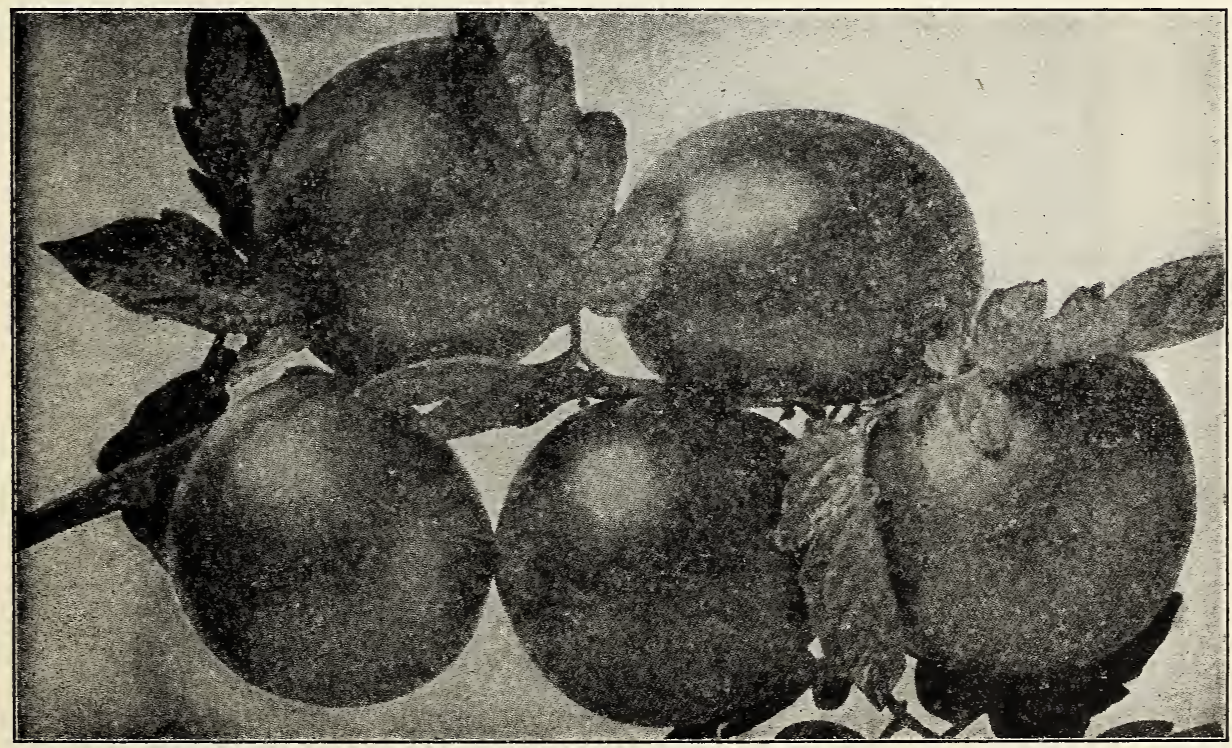

Bonny Best 


\section{TOMATOES-Continued}

Beauty Livingston's. Purplish pink in color; large and solid. $1 / 2$ oz. $20 \notin$, oz. $30 \notin, 1 / 4 \mathrm{lb} . \$ 1.00$, lb. $\$ 3.75$.

Dwarf Stone Livingston's. Vine dwarf and stocky, producing large, smooth, red fruits. $1 / 2$ oz. 20 , oz. 30 \&, $1 / 4$ lb. $\$ 1.00$, lb. $\$ 3.75$.

Greater Baltimore. A large red tomato somewhat similar to Matchless. Very productive and excellent main crop. $1 / 2$ oz. $20 \dot{k}$, oz. $30 k, 1 / 4 \mathrm{lb} . \$ 1.00$, lb. $\$ 3.75$.

* Stone Livingston's. A fine all-around Tomato; bright red. A standard for general use. $1 / 2 \mathrm{oz}$. 15 , oz. 25 k, $1 / 4$ lb. 80 \&, lb. $\$ 3.00$.

* Matchless. A vigorous grower and great yielder of rich, cardinal red fruits of exceptional merit. A splendid keeper and shipper, and unsurpassed for home or market purposes. $1 / 2 \mathrm{oz}$. 20 \&, oz. 30 \&. $1 / 4$ lb. $\$ 1.00$, lb. $\$ 3.75$.

Earliana Sparks. An extra-early sort, and very productive. The fruits are of good size, fairly uniform, bright red and firm. $1 / 2$ oz. $15 \phi$, oz. $25 \phi, 1 / 4$ lb. $80 \phi$, lb. $\$ 3.00$.

Wayahead. A very early, smooth, solid red Tomato with potato leaved foliage about same size and claimed to ripen a few days earlier than Earliana. $1 / 2$ oz. 20 \&, oz. 30 \&, $1 / 4$ lb. $\$ 1.00$, lb. $\$ 3.75$.

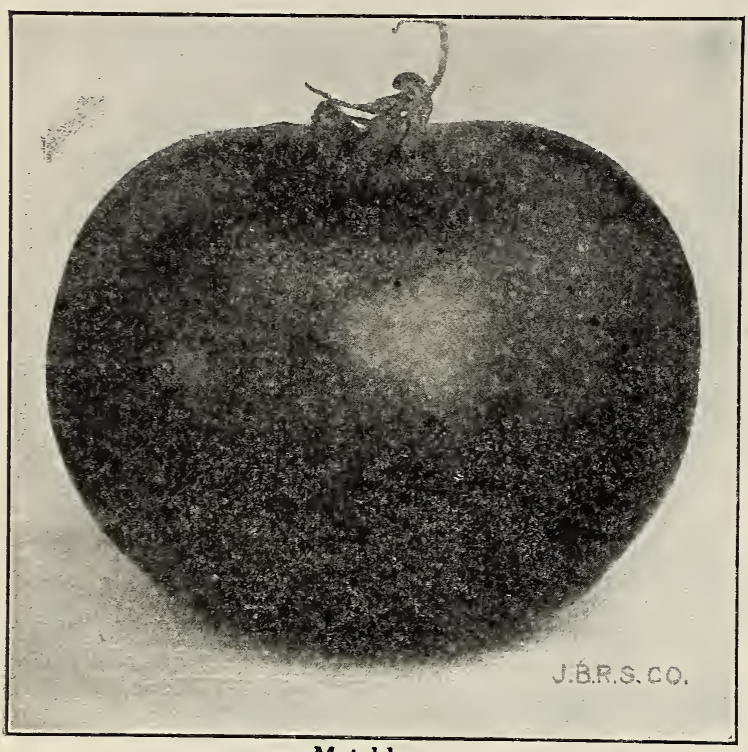

\section{SMALL FRUITED VARIETIES}

The plants of the miniature or fancy Tomatoes are extremely prolific. Highly esteemed for preserves and pickles; also very ornamental when used for garnishing.

Pear-shaped Yellow. 1/2 oz. 15k, oz. 25 \&. $1 / 4$ lb. 90 \&, lb. $\$ 3.50$.

Yellow Cherry. $1 / 2$ oz. 15ф, oz. $25 \phi$, $1 / 4$ lb. 90 \&, lb. $\$ 3.50$.

Yellow Plum. 1/2 oz. 15ф, oz. 25 , 1/4 lb. 90 \&. lb. $\$ 3.50$.

Strawberry, or Husk Tomato. The small fruits of this singular variety are yellow and each enclosed in a paper-like husk; they are used for preserving. $1 / 2$ oz. $15 \phi$, oz. 25 \&, $1 / 4$ lb. 90 .

For discount on large orders see terms, inside front cover. If your order is small make up a club order and take advantage of the discount.

Matchless

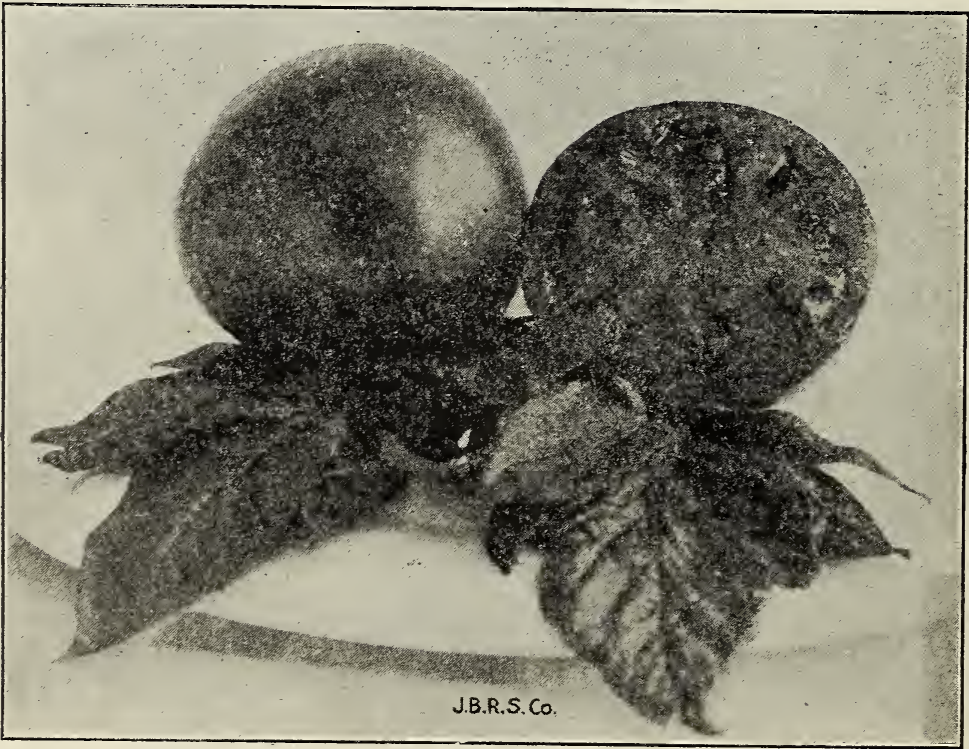

Wayahead 


\section{NAVONE TURNIP}

RZEPA BRUKIEW

Culture - The Turnip is a cool weather crop and should be sown very early in the Spring for early use, generally in drills 15 to 18 inches apart sowing the early varieties and sow the later sorts broadcast last of July or August for late Fall and Winter use. Ruta Baga should be sown in June in rows 2 feet apart and thinned to 4 to 6 inches. One ounce will sow 150 feet of drill; 2 pounds to an acre.

Extra Early Purple Top Milan. One of the earliest varieties in cultivation. Medium size and smooth; white with purple top; flesh white, firm and mild; good for early use only. Oz. 10ф, $1 / 4$ lb. 35 c. lb. 85 \&. 5 lbs. or more, per lb. 75 \&.

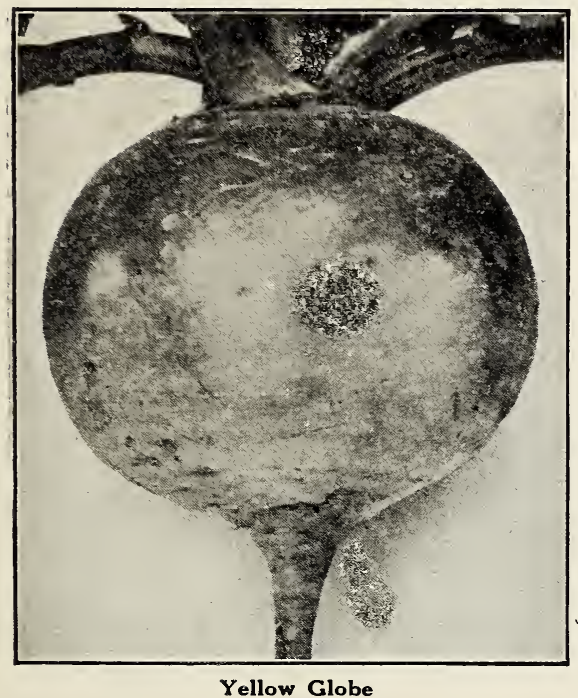

Early Snowball, or Six Weeks. Desirable for table use and a favorite early market variety. Medium size, round and snowy white. Oz. $10 \notin$. $1 / 4$ lb. 25 c, lb. $60 \phi .5$ lbs. or more, per lb. 50 c.

Large Red Top Globe. A large white globular Turnip with red top; fine for both market and private use. Oz. $10 \phi, 1 / 4$ lb. $25 \phi$, lb. $60 \notin, 5$ lbs. or more, per lb. 50 .

Purple Top Flat Strap-leaved. Good cropper and splendid variety for Fall table use and stock feeding. Bright purple top with white flesh of mild flavor. Oz. $10 \xi, 1 / 4$ lb. $25 \xi$, lb. $60 \xi, 5$ lbs. or more, per lb. $50 \phi$.

$\star$ White Egg. A beautiful egg-shaped bulb of quick growth. Thin white skin; flesh pure white, firm and sweet. Fine for Fall and early Winter use. Oz. $10 \notin, 1 / 4$ lb. 25 , lb. 60 , 5 lbs. or more, per lb. 50 ć.

$\star$ Yellow Globe. Fine for table use or feeding stock. Grows to a good size and is a reliable Winter keeper. Yellow with green top fine grained and very tender. Oz. $10 \AA .1 / 4$ lb. 25 . lb. $60 \phi$. 5 lbs. or more, per lb. $50 \notin$.

Yellow Stone. Stands among the best of yellowfleshed Turnips. Globe shaped, of high quality, and a prime keeper. Oz. $10 \notin, 1 / 4$ lb. $25 \xi$. lb. $60 ф .5$ lbs. or more, per lb. $50 \phi$.

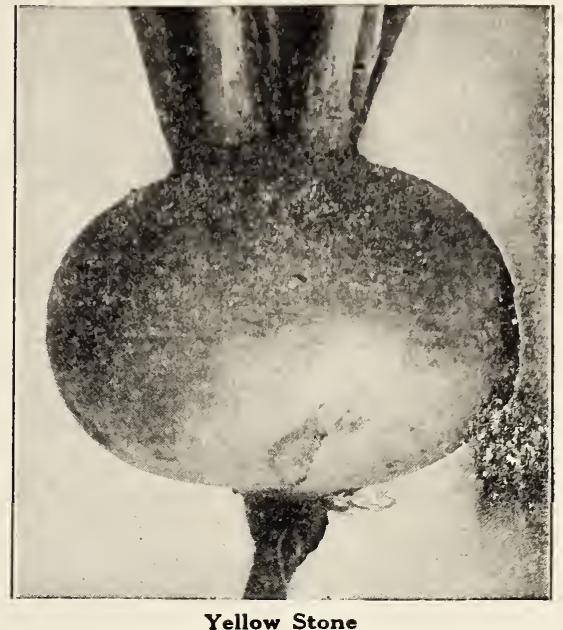

\section{RUTA BAGA, or SWEDISH TURNIP}

$\star$ American Improved Purple Top Yellow. Widely grown and justly styled the market gardener's favorite. A good cropper and keeps perfectly through the Winter. Flesh rich yellow, solid and sweet. Oz. 15 \&, 1/4 lb. 35 , lb. 75 \&. 5 lbs. or more, per lb. $60 \phi$.

Breadstone, or Budlong. A superior white variety of medium size. Oz. $15 \phi, 1 / 4$ lb. $35 \phi$, lb. $75 \phi$, 5 lbs. or more, per lb. 60 c.

Long Island Improved Purple Top. Large size, very productive and an especially good keeper. Flesh rich yellow, sweet and nutritious. Oz. $15 k$. $1 / 4$ lb. 35 \&. lb. 75 \&, 5 lbs. or more, per lb. 60 \&.

$\star$ White French, or Rock. A large, whitefleshed variety of choice quality. Oz. $15 \xi, 1 / 4 \mathrm{lb}$. 35 . lb. 75 ф, 5 lbs. or more, per lb. 60 .

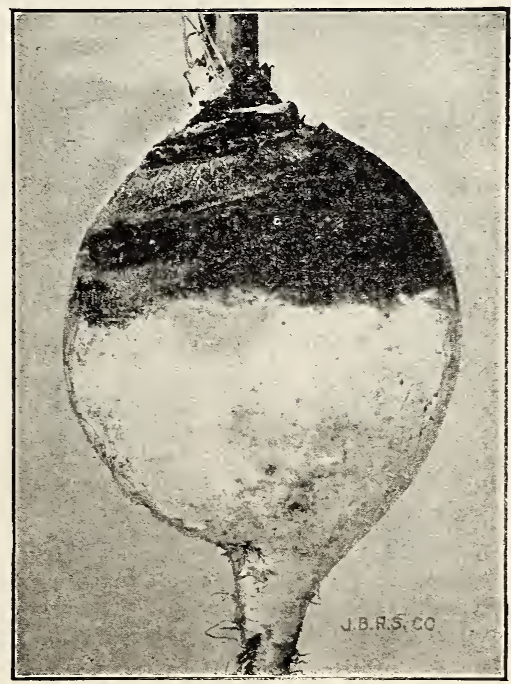

American Improved Purple Top Yellow 


\section{GRASS SEEDS}

We handle high grade seed and will quote reasonable price on application. It is poor policy to purchase inferior seed at any price as the buyer looses in the end. The market fluctuates. Write for prices.

Kentucky Blue Grass (Poa pratensis). Unrivaled as a pasture Grass and generally used in Lawn Grass Mixtures. Thrives well everywhere. Sow 35 to 40 lbs. per acre.

Meadow Fescue (Festuca pratensis). It is a favorite variety, of quick growth; of great value for hay by frost so it cannot become a pest like some of the other large grasses. Sow 15 to 20 lbs. per acre.

Sheep Fescue (Festuca ovina). A splendid Grass for sheep pastures; also well adapted for lawns, being of short, thick growth. Sow 30 lbs. per acre.

Tall Meadow Oat Grass (Avena elatior). Of early' and luxuriant growth, and valuable for hay or pasturing. Sow $30 \mathrm{lbs}$. to the acre.

Timothy, or Herd Grass (Phleum pratense). Grown in all sections and produces most profitable. hay crops. Is of ten sown with other Grass seeds.

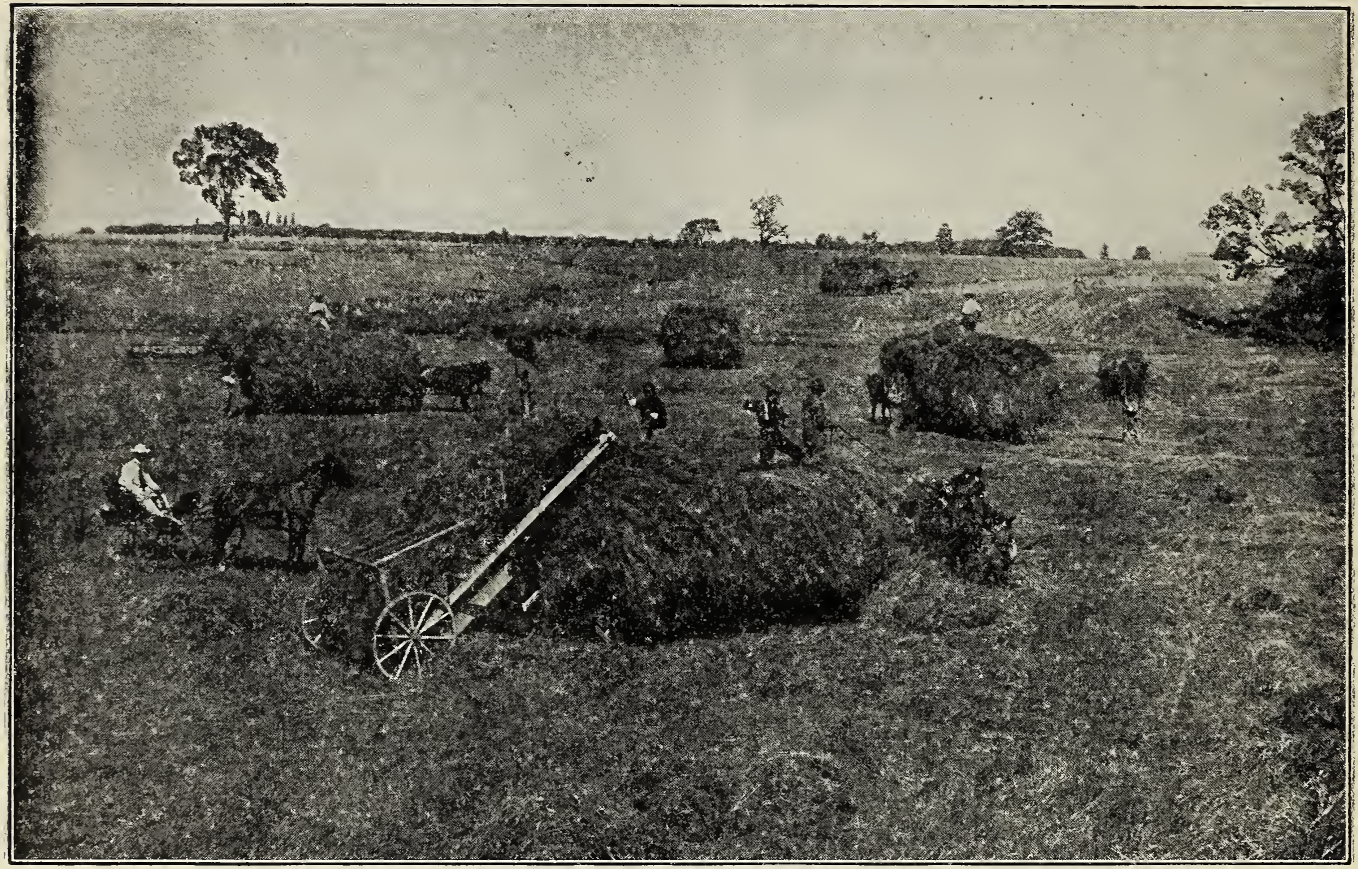

or permanent pasture. Grows well most anywhere, but best in medium and heavy soils. Sow 40 lbs. per acre.

Orchard Grass (Dactylis glomerata). Excellent for pastures; grows well in shady places and under trees. A natural covering for orchards. Many use it in grass mixtures. Sow 25 to $35 \mathrm{lbs}$. per acre.

Perennial Rye Grass (Lolium perenne). A permanent, nutritious, meadow and pasture Grass. Sow 50 lbs. per acre.

Red Top (Agrostis vulgaris). Highly recommended as one of the most valuable Grasses for hay and permanent pasture. Does well in most any soil but better adapted to rich sandy loam. Used extensively in hay and pasture mixtures. Sow $20 \mathrm{lbs}$. to the acre.

Sudan Grass. Can be grown in almost any section as it is not affected greatly by temperature. Is drought resisting, yet excessive moisture does not injure it much, and it leads all other grasses in quantity of yield. It is an annual and killed
Very extensively sown in the East. Sow 20 lbs. per acre. (Bushel, 45 lbs.)

\section{CLOVER SEED}

Alfalfa, or Lucerne (Medicago sativa). Requires a deep, fertile, well-drained soil. A field of well established Alfalfa is very valuable feed. However, it requires considerable work and expense to get it established here in the East. In preparation for the seed the soil should be thoroughly pulverized and well enriched with fine manure or fertilizer. An application of lime is beneficial in most cases. It will not do well on land where water stands any length of time. Early June and August are good times to sow the seed; harrow it in lightly and roll it if possible. If the weeds get ahead of the Alfalfa mow them before they go to seed raising the knives well up to avoid injury to the Alfalfa, and let the weeds lie as a mulch if not too thick. Alfalfa is a very heavy cropper and when thoroughly established can be cut three or four times a year. Sow 20 to $30 \mathrm{lbs}$. to the acre. (Bushel, 60 lbs.) 


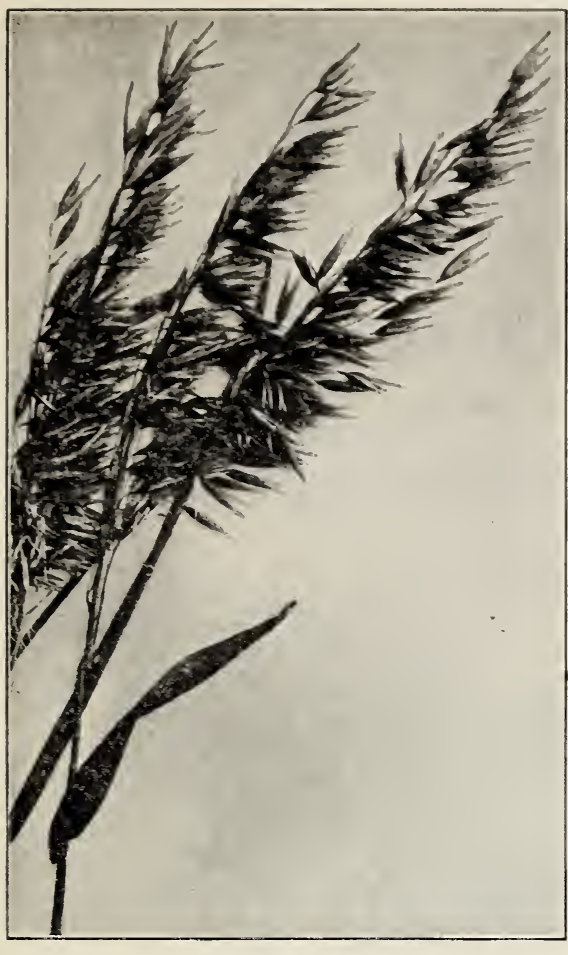

Orchard Grass

Grimm Alfalfa. A very hardy variety well adapted to New England and Northern sections of the country. Although the seed is more expensive, many are sowing it as they claim it is more hardy. Sow 20 to 30 lbs. per acre.

Alsike, or Swedish Clover (Trifolium hybridum). An intermediate between Red and White Clover. The hardiest of perennial Clovers and on rich, moist soil yields huge crops of hay or pasturage. It is especially valuable when sown with other Clovers and Grasses. Makes excellent forage for cattle, and its fragrant heads are much liked by honey bees.

Sow 10 lbs. per acre. (Bushel 60 lbs.)

Crimson, or Scarlet (Trifolium incarnatum). On fertile soil this popular Clover grows luxuriantly and produces an early Spring pasture. Valuable for green forage and for hay; also as a cover crop and soil improver. Sow 15 to 20 lbs. per acre. (Bushel 60 lbs.)

Mammoth Red, or Pea Vine (Trifolium pratense perenne). Sturdier, grows to a much larger size, and lasts longer than the ordinary Red Clover. $A$ good soil renovater when plowed under as green manure. Sow 10 to 15 lbs. per acre. (Bushel, 60 lbs.)
Medium Red (Trifolium pratense). For practical purposes this is regarded as the most valuable of all the varieties, and is largely sown in all sections. Sow 10 to $15 \mathrm{lbs}$. per acre. (Bushel, 60 lbs.)

White Dutch (Trifolium repens). A'small, creeping perennial of dense growth, invariably used in lawn mixtures. It is also of much value when sown in combination with other Grasses for permanent pastures. If used alone sow 8 to $10 \mathrm{lbs}$. to the acre, or $4 \mathrm{lbs}$. in a mixture.

\section{GRASS SEED MIXTURES}

Many have their own formulas for grass seed mixtures, but we suggest the following mixtures as a help to those that are not familiar with the different varieties of grasses.

For Hay (Light and Medium Soils). 10 lbs. Timothy, 7 lbs. Red Top, 4 lbs. Alsike Clover, 4 lbs. Medium Red Clover. (25 lbs. per acre.)

For Hay (Heavy Soil). 8 lbs. Timothy, 7 lbs. Red Top, 4 lbs. Alsike Clover, 3 lbs. Medium Red Clover, 3 lbs. Orchard Grass. (25 lbs. per acre.)

For Orchards and Shady Places. 15 lbs. Orchard Grass, 5 lbs. Red Top, 3 lbs. Alsike Clover, 4 lbs. Meadow Fescue, 3 lbs. Tall Meadow Oat Grass. (30 lbs. per acre.)

For Permanent Pastures. 5 lbs. Red Top, 3 lbs. Orchard Grass, 5 lbs. Meadow Fescue, 5 lbs. Kentucky Blue Grass, 3 lbs. Perennial Rye Grass, 3 lbs. Tall Meadow Oat Grass, 2 lbs. Alsike Clover, 4 lbs. White Clover. (30 lbs. per acre.) For Lawn Grass seed mixtures See page 39.

\section{MILLET}

Golden (Panicum miliaceum aureum). A medium early, large-leaved variety growing 3 to 5 feet in height. Matures later than Hungarian Millet and is a liberal cropper. The heads are compact and well filled. Sow 1 bushel per acre. (Bushel, 50 lbs.)

Grass Seed prices fluctuate.

Write for quotations.

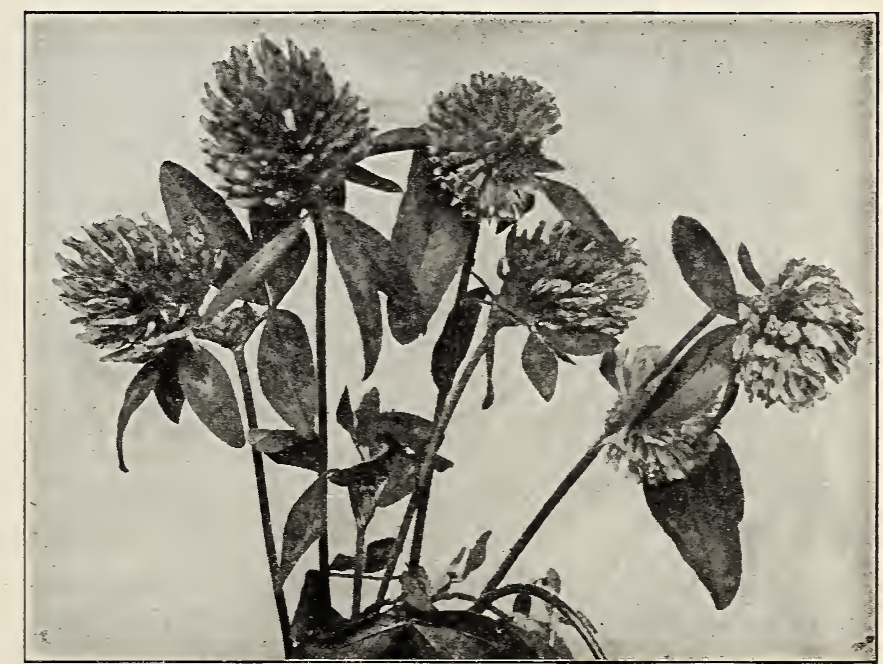

Alsike or Swedish Clover 


\section{GRASS SEEDS-Continued}

Hungarian (Panicum Germanicum). Sown in June, this well-known Summer forage crop is ready for cutting in about sixty days. It is also extensively sown in July and fore part of August after hay crop has been harvested, and helps out the supply of hay immensely. Resists heat and drought well. Sow one bushel per acre. : (Bushel, 48 lbs.)
Japanese, or Barnyard (Panicum Crus-galli.) Very tall grower on fertile soil, often attaining a height of 5 to 6 feet. A great fodder plant, and an extremely heavy yielder. Continues to grow after cutting and is extensively sown by dairymen and stock raisers. Sow 20 to $25 \mathrm{lbs}$. to the acre. (Bushel, 32 lbs.)

Millet prices fluctuate. Please write for prices when wanted and state quantity desired.

\section{Seed Oats}

Special quotation for large quantity on application.

Oats sown in early Spring make an excellent green feed especially when sown with Canada Field Peas and fed green or can be cured for hay to help out the hay supply. Good mixture, 2 bushel oats with $11 / 2$ bushel Canada Field Peas per acre. less quantity to seed an acre and the yield is greater. 4 qts. $40 \phi$, pk. $60 \phi$, bus. $\$ 1.60,2$ bus. or more, per bus. $\$ 1.50$.

\section{THE BIG WONDER}

It is a tree or branching type of Oats that yield heavily of large, white, thin-hulled grain. Straw large and stout. These Oats grow big and heavy and we advocate sowing less per acre than ordinary varieties. $11 / 2$ to 2 bushels per acre on good soil is plenty for best results. While this variety costs little more per bushel, the difference is easily made up as it takes

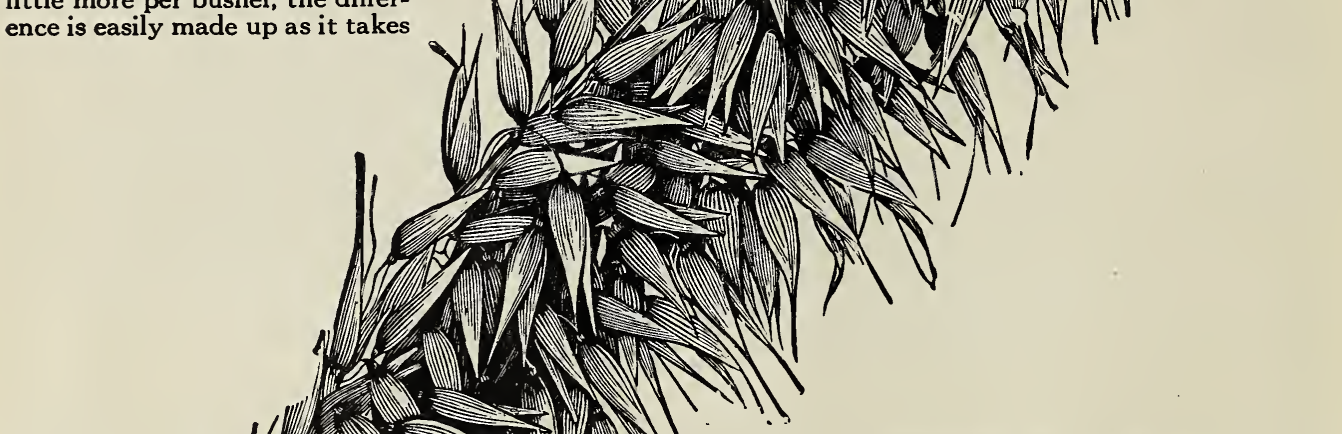

\section{SWEDISH SELECT}

A large, heavy ${ }^{\circ}$ Oat of Swedish origin that has proved to be very valuable and a favorite in this country. It is an excellent variety to sow for the grain or for a heavy leafy straw for hay or green feed. The demand for this variety is heavy. 4 qts. $30 \notin$, pk. $50 \notin$, bus. $\$ 1.50,2$ bus. or more, per bus. $\$ 1.40$.

\section{SILVER MINE}

This is generally recognized as a prolific cropper and one of the most profitable varieties grown. It makes a sturdy growth of straw, which stands up well, and the heads are filled with beautiful white, plump grains. 4 qts. $30 \notin$, pk. $45 \notin$, bus. $\$ 1.45,2$ bus. or more, per bus. $\$ 1.35$.

\section{COMMON SEED OATS}

These are good Oats without any particular name and will do very well to sow for hay or green feed where anyone is not particular as to variety. $4 \mathrm{gts}$. $25 \phi$, pk. $40 \notin$, bus. $\$ 1.25,2$ bus. or more, per bus. $\$ 1.15$. 


\section{Farm Seeds \\ Field and Ensilage Corn}

Write for special price on 5 bushels and upward of same variety

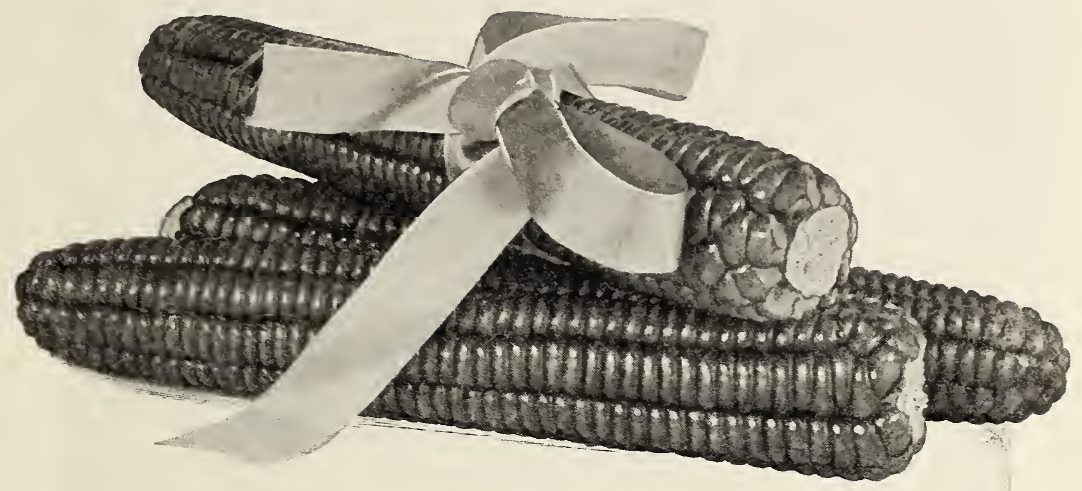

Canada Yellow Flint

\section{* CANADA YELLOW FLINT (Prize Winner Stock)}

We have a choice stock of this valuable variety that is so well adapted and so generally grown in New England. An ideal corn for this climate. It is early, a heavy cropper with very bright yellow ears, medium long and well filled out. Qt. $20 \notin .4$ gts. $55 \phi$. pk. $\$ 1.00$, bus. $\$ 3.50,2$ bus. or more, per bus. $\$ 3.25$.

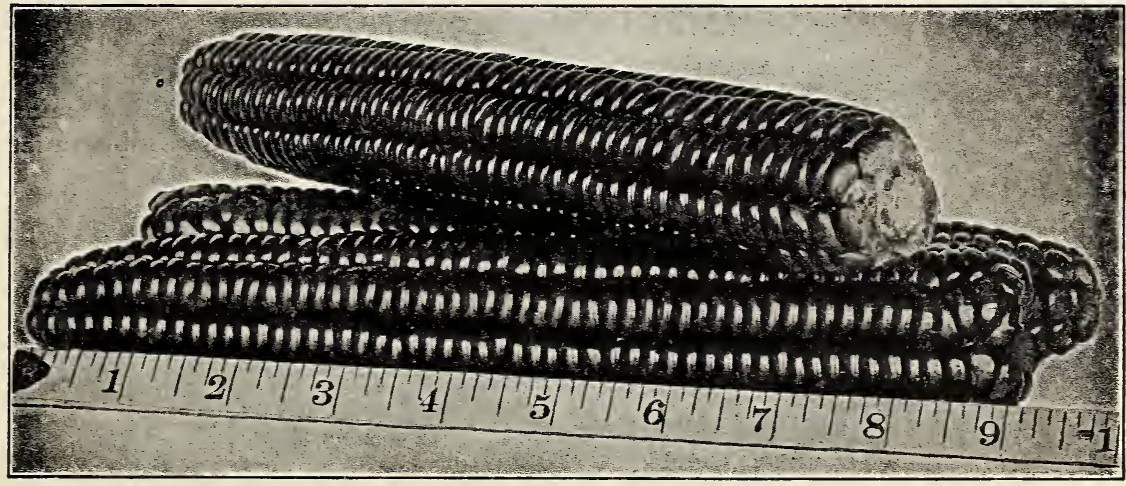

Longfellow Yellow Flint

\section{LONGFELLOW YELLOW FLINT}

A beautiful, eight-rowed Flint variety, similar in type and growth to Canada Yellow, but bears longer ears, and week or two later in maturing. The grain is yellow and of good size. Well adapted for planting in most any part of New England. It is grown in large quantities in many sections, and planters are well satisfied with the crops. Qt. $20 \notin, 4$ qts. $55 \xi$, pk. $\$ 1.00$, bus. $\$ 3.50,2$ bus. or more, per bus. $\$ 3.25$. 


\section{* CLARK'S EARLY SMOKY DENT}

The more this excellent Dent variety of corn is known, the better it is liked, and it is being planted quite extensively.

It is a very hardy grower, and prolific yielder for so early a corn. This corn has nice leafy stalks, averaging 8 feet or more in height, which very often carries two nice ears measuring 8 to 10 inches in length, well filled with a good sound kernel, with a dark red shade, tipped with pure white, making it a very handsome corn in appearance.

This corn can be grown with success anywhere that Early Canada Flint Corn matures, as we find it

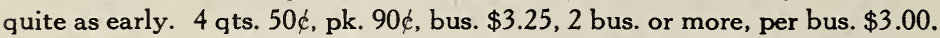

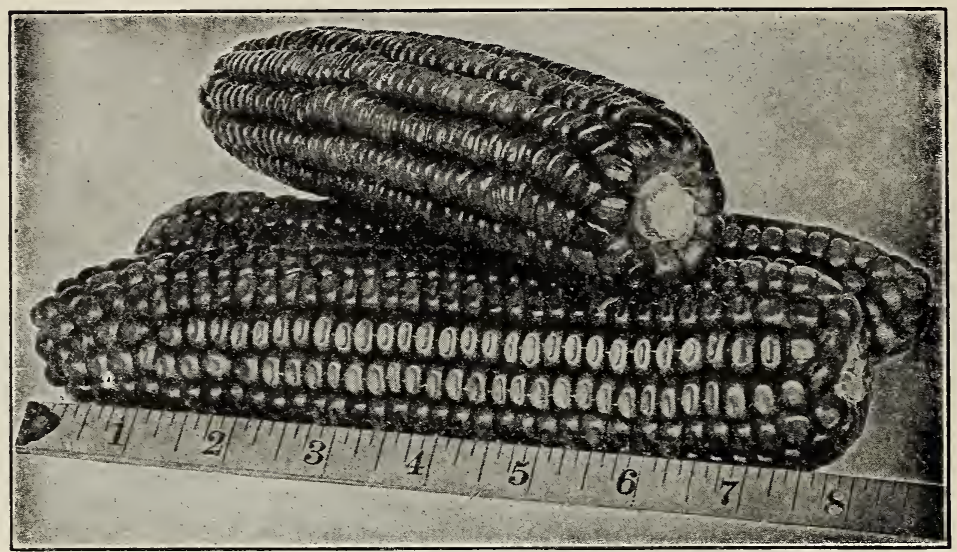

Pride of the North

\section{PRIDE OF THE NORTH}

This is a very satisfactory variety of Dent Corn for New England and produces a wealth of handsome ears of uniform size, with fairly long, deep yellow, dented kernels. Matures in about ninety days. 4 qts. $50 \notin$, pk. 90 , bus. $\$ 3.25,2$ bus. or more, per bus. $\$ 3.00$.

\section{$\star$ IMPROVED LEAMING}

An ideal yellow Dent Ensilage Corn and popular everywhere. A tall grower and prolific yielder. Many stalks produce two long ears, with small cobs filled with deep, well dented, golden yellow grains. Ripens in from 110 to 120 days. The leafy stalks make splendid fodder. An exceedingly valuable variety for ensilage. 4 qts. $50 \xi$, pk. $80 \xi$, bus. $\$ 3.00,2$ bus. or more, per bus. $\$ 2.75$.

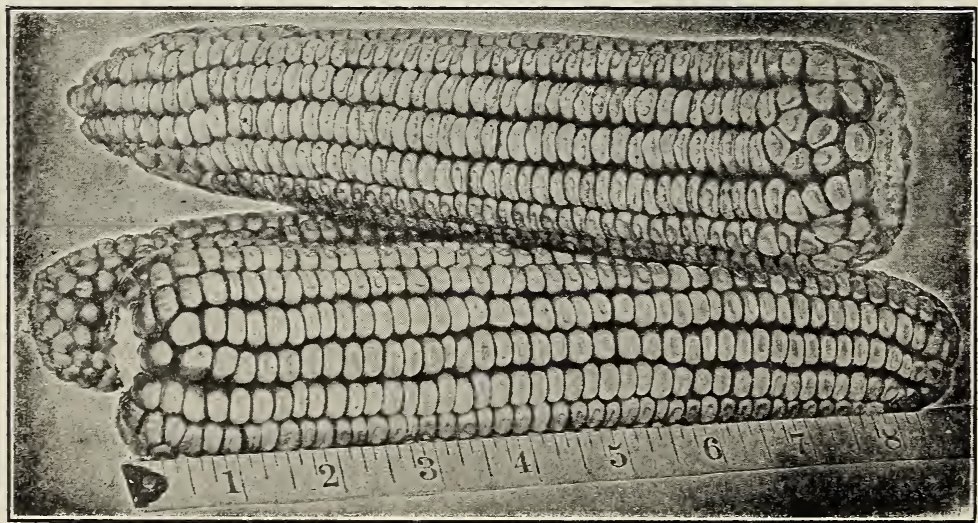

Improved Leaming 


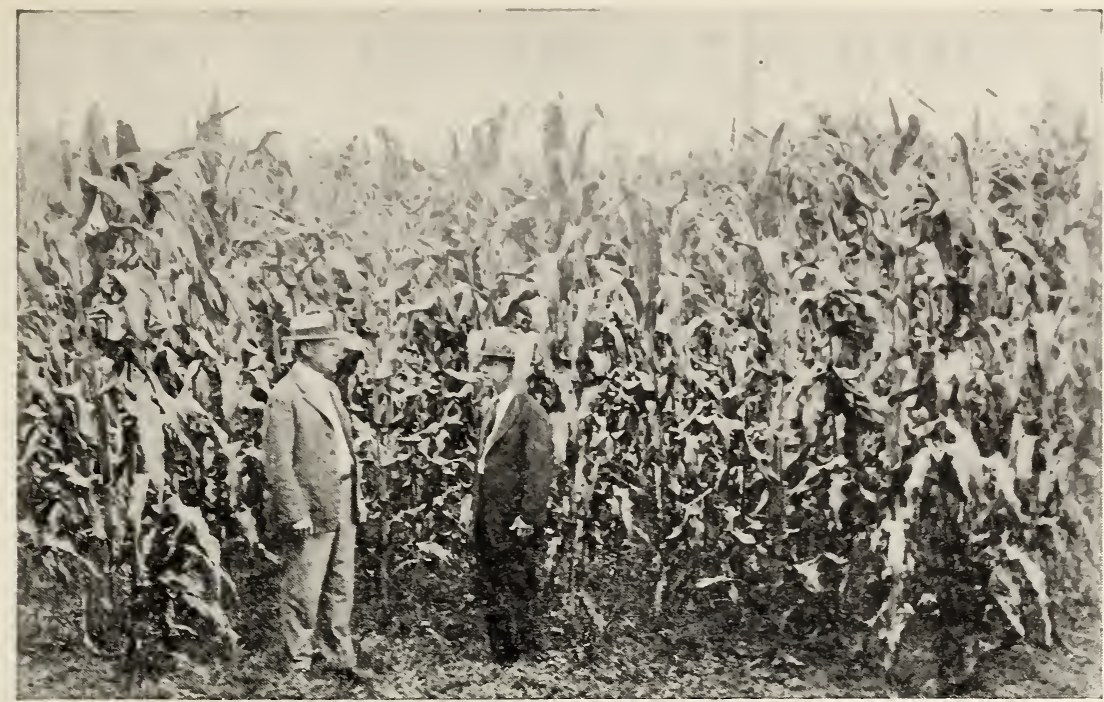

Field of New England Ensilage Corn

\section{* NEW ENGLAND ENSILAGE CORN}

This is a very large yellow Dent variety maturing as early as Improved Leaming and while it grows nearly as large as Eureka White Dent it matures much earlier which makes it a very valuable Ensilage Corn, well adapted to our Eastern climate. The stalks grow large, tall and very leafy, producing great quantities of fodder and the ears large, long and well filled out, maturing in this climate early enough to gather if planted fairly early. It is an ideal ensilage corn, for New England climate. 4 qts. 55c, pk. $\$ 1.00$, bus. $\$ 3.50,2$ bus. or more, per bus. $\$ 3.25$.

\section{SWEET CORN FOR FODDER}

Every year we have some crops and odds and ends of sweet corn that are a little off color or perhaps a little mixed and not up to standard but of good germination and these lots of the late varieties we sell as fodder corn and many are planting this corn to help out the fodder supply. 4 qts. $55 \dot{k}$, pk. $\$ 1.00$, bus. $\$ 3.50$, 2 bus. or more, per bus. $\$ 3.25$.

\section{Quantity of Seeds Required to Plant or Sow an Acre}

\begin{tabular}{|c|c|c|c|c|c|}
\hline KIND & $\begin{array}{l}\text { Quantity } \\
\text { per Acre }\end{array}$ & 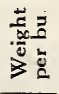 & KIND & $\begin{array}{l}\text { Quantity } \\
\text { per Acre }\end{array}$ & 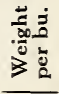 \\
\hline 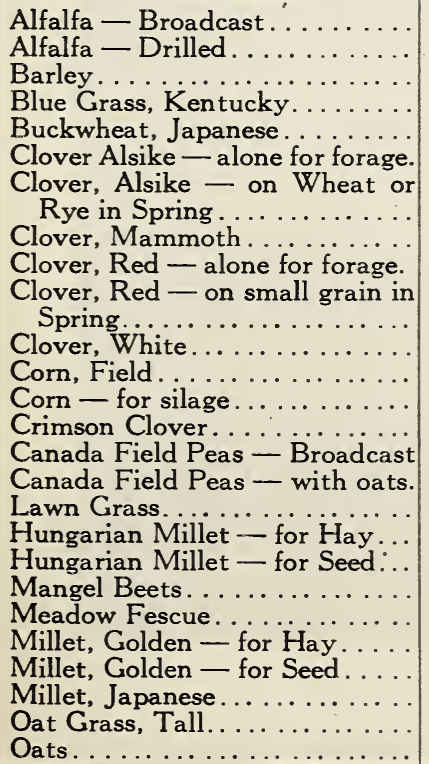 & 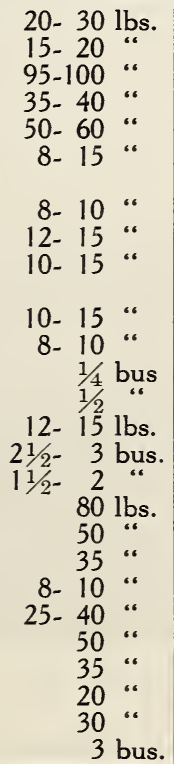 & $\begin{array}{l}60 \\
56 \\
60 \\
60 \\
\\
20 \\
48\end{array}$ & 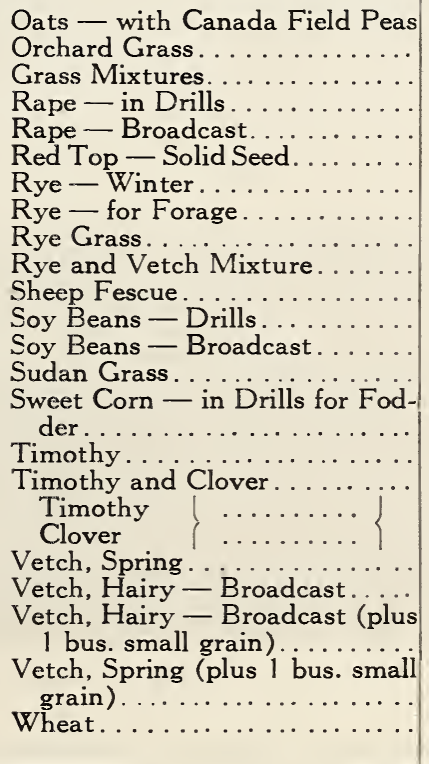 & 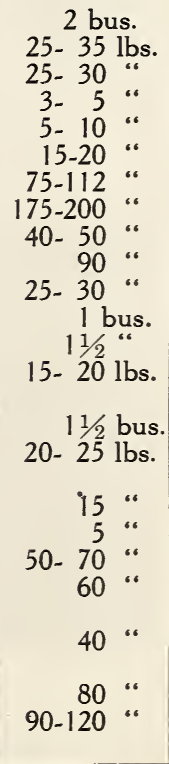 & $\begin{array}{l}18 \\
60 \\
12 \\
60\end{array}$ \\
\hline
\end{tabular}




\section{FIELD PEAS AND SOY BEANS}

These field Peas and Beans are valuable for stock feeding purposes and for plowing under to renovate and enrich the soil.

\section{CANADA FIELD PEAS}

This is an exceptionally hardy field Pea, of great value as a feed for stock and worthy of a place on every farm. The vine grows to a height of $31 / 2$ feet and bears a profusion of small, round peas. Most satisfactory results are obtained from sowing with Oats or Barley, the combination being very nutritious and of special importance for cattle feeding. The crop is serviceable for soiling and plowing under as a green manure, and it also makes good ensilage. Sow broadcast, $11 / 2$ bus. Peas with 2 bus. of Oats or Barley. Write for prices.

\section{SOY BEANS}

The Soy Beans are somewhat similar to the Southern Cow Pea, but are much better adapted in this climate. They make excellent green feed and some hay them and they are valuable as a green manure.

They produce enormous crops and great resister of drought and heat. We offer the following varieties:

Early Hollybrook and Mammoth Yellow. Prices on application.

\section{MISCELLANEOUS}

\section{Write for Prices.}

Dwarf Essex Rape. Especially desirable for green manuring and pasture; also of considerable commercial value as a forage for stock and poultry; for sheep and swine it is a particularly fine feed. Seed may be sown in May for Summer crops and in June and July for Fall feeding. Sow 3 to 5 lbs. per acre in drills; 8 lbs. per acre broadcast (Bushel, $60 \mathrm{lbs}$.)

Buckwheat, Japanese. is variety is of stronger growth and produces larger grain than the common Buckwheat. (Bushel, 48 ivs.)

Barley. Select, recleaned and dependable seed; sown extensively in New England for fodder. (Bushel, 48 lbs.)

Rye, Rosen Winter. Grown for hay by dairymen, but principally for grain, is also sown extensively with vetch, the combination makes an excellent fodder and green manure to plow under. (Bushel, $56 \mathrm{lbs}$.)

Rye and Vetch Mixture. This is a good mixture for early Spring feed and for a Winter covering to plow under in Spring, and it has proven a satisfactory crop, preventing the land from washing, and greatly improving and enriching the soil. Sow any time between August 1 and October 15 to ensure a good stand before freezing weather sets in; about $11 / 2$ bushels to the acre. (Bushel, $60 \mathrm{lbs}$.)

Vetch, Russian Sand, or Hairy. A hardy forage plant, and very productive. Its extensive root growth and nitrogen-gathering properties make it particularly valuable as a soil fertilizer. Sow seed in August or September at the rate of 40 to $60 \mathrm{lbs}$. per acre. It does not show much until the following spring.

Vetch, Spring, or Tares. A Pea-like variety generally sown broadcast alone or with Oats or Barley. Sown in Spring, it yields a large crop of nutritious hay; also esteemed as a soil improver. Sow 2 bushels to the acre. (Bushel, 60 lbs.)

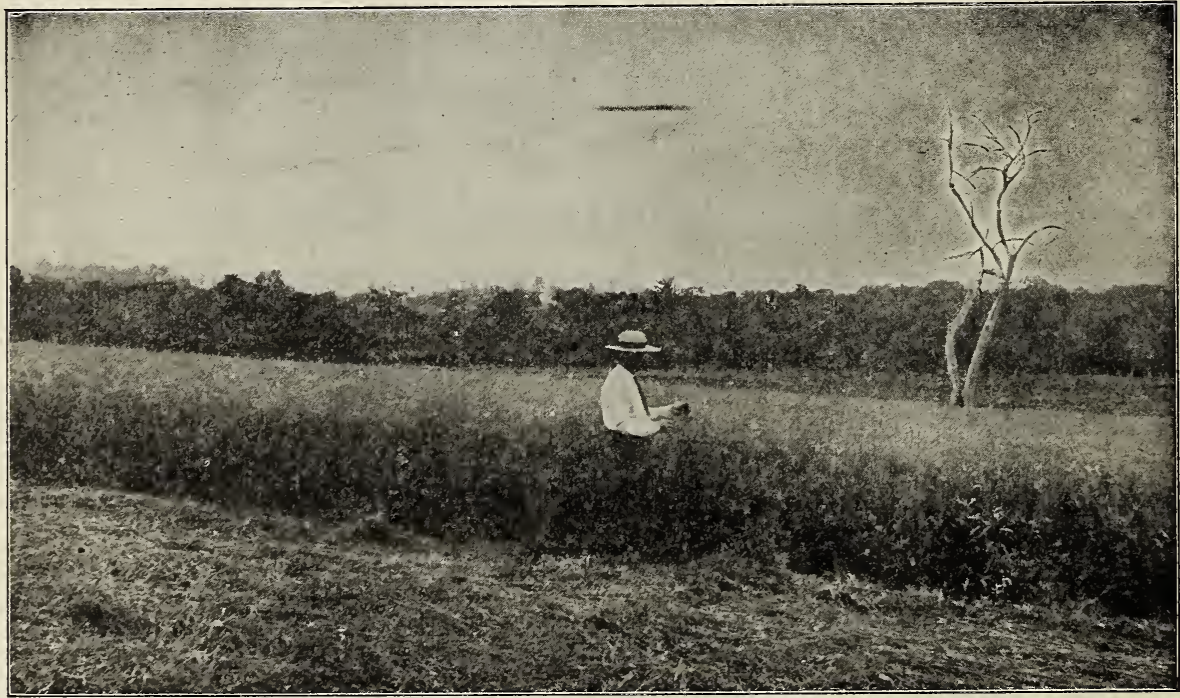

Field of Canada Field Peas with Oats

We conduct our business direct from our seed farms and our expenses are comparatively light. 


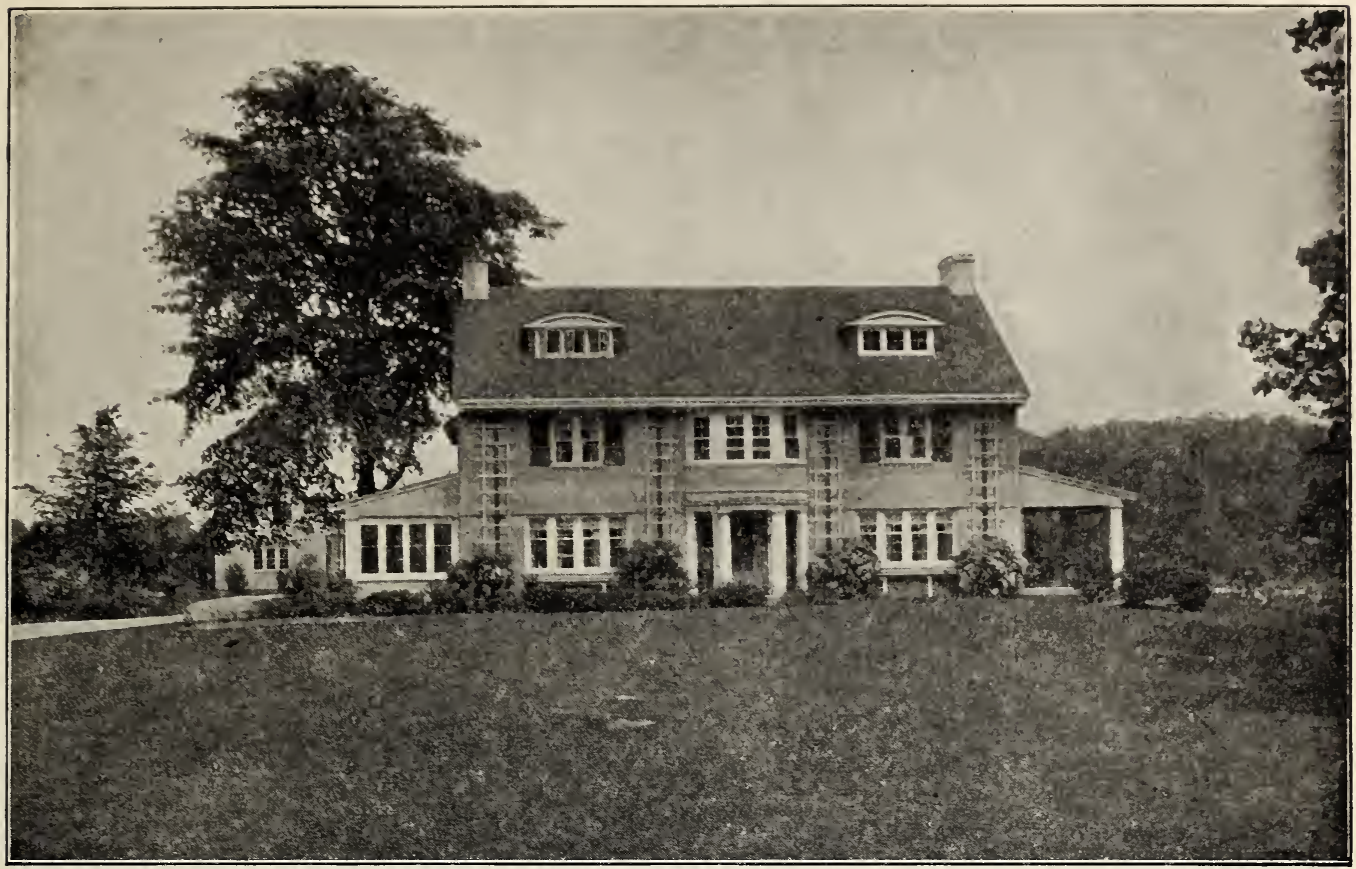

\section{HOW TO PREPARE AND MAINTAIN A LAWN}

Keep your lawn in good condition by sowing a little new seed, and top dressing it occasionally with fine stable manure or some good fertilizer and often save the expense of plowing and reseeding the lawn.

Lawn Grass seed may be sown any time between April and the end of September. Some gardeners claim that the best lawns are produced by sowing in early Spring; others consider the Fall the most desirable season, because the conditions are then ideal for the rapid germination of seed, the roots become firmly established before the severe Winter sets in, and with the advent of warm weather in Spring the Grass starts into luxuriant growth; while the strong roots enable it to resist the scorching heat of Summer.

To ensure a good and permanent lawn, the soil should be clean, enriched with well-rotted stable manure, thoroughly pulverized to a depth of 6 to 9 inches, and fairly moist when the seed is sown. Having made the surface as fine and level as possible with a ra ke or harrow, sow the seed broadcast, choosing a calm day for the operation, so that it may be evenly distributed. Cover the seed by going over the surface with a fine rake and afterward with a roller. It is important to thoroughly roll the lawn after sowing the seed to press the seed in firmly and make a hard smooth surface.

Lawns are benefited and improved in appearance by frequent mowing until the Grass ceases to grow in the Fall. Stable manure is often spread over the lawn when the ground freezes and removed in early Spring, but as this treatment produces an unsightly effect, many prefer to use commercial fertilizers as a top dressing. It is an excellent practice to renovate and freshen the lawn every Spring or Fall with a little new seed. Bare sports should be loosened with a sharp rake and given a good dressing with fertilizer before sowing the seed. One pound of seed is required for 500 square feet. 20 pounds for one quarter acre, 80 pounds for an acre.

\section{LAWN GRASS MIXTURES}

We have several choice Lawn Grass Mixtures consisting of grasses best adapted and mixed in right proportions to insure the best of lawns.

Fancy Lawn Grass Mixture. For Lawns in general. Lb. $35 k, 5$ lbs. $\$ 1.70,10$ lbs. $\$ 3.30,25$ lbs. $\$ 8.00$, 50 lbs. $\$ 15.50,100$ lbs. $\$ 30.00$.

Special Lawn Grass Mixture. With abundance of White Clover. Lb. 40 \&, 5 lbs. $\$ 1.95,10$ lbs. $\$ 3.80$, 25 lbs. $\$ 9.25,50$ lbs. $\$ 18.00,100$ lbs. $\$ 35.00$.

Special Lawn Grass Mixture. For shady places. Lb. 45 \&, 5 lbs. $\$ 2.20,10$ lbs. $\$ 4.30,25$ lbs. $\$ 10.50,50$ lbs. $\$ 20.50,100$ lbs. $\$ 40.00$. 


\section{FLOWER SEEDS}

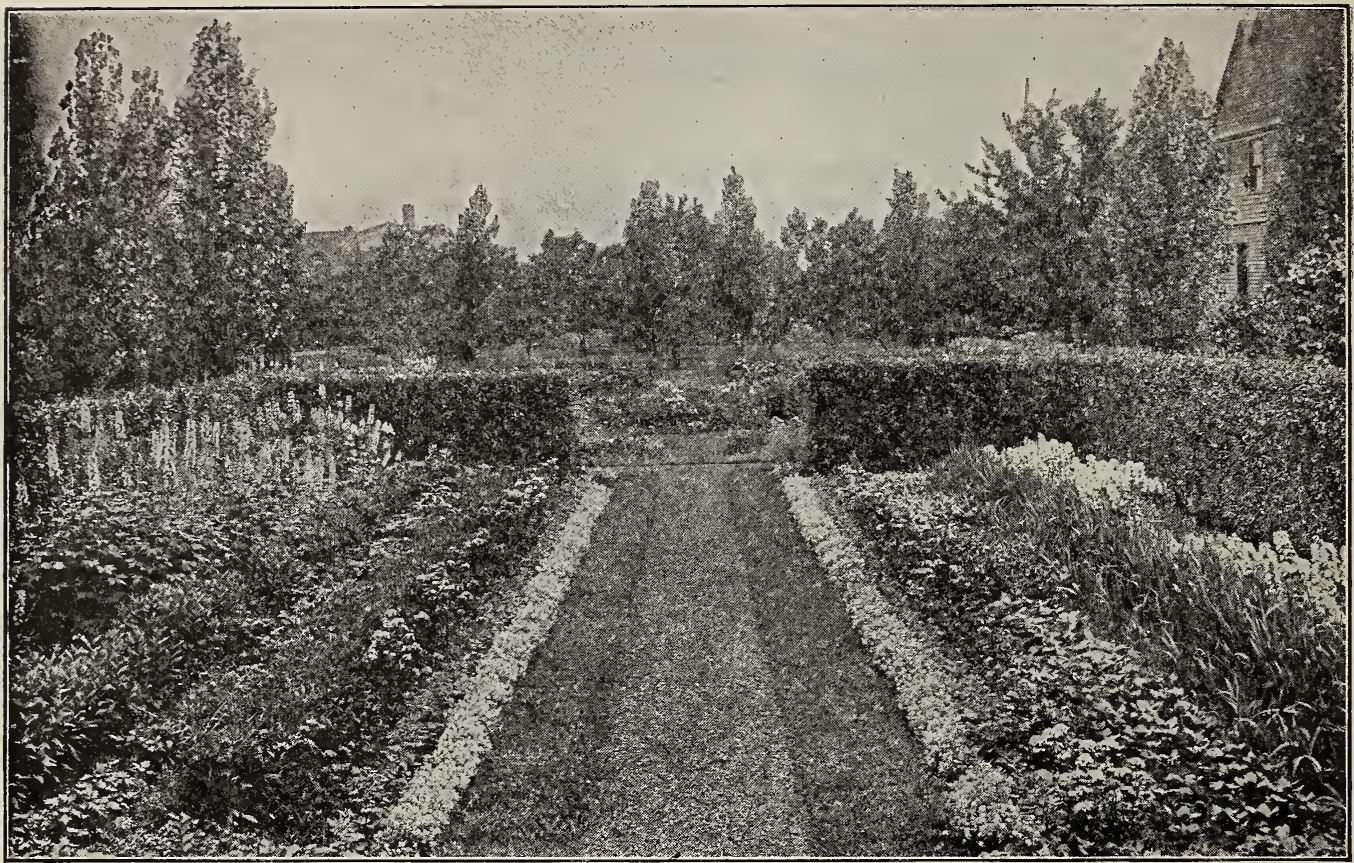

We list flower seeds mostly in mixtures and do not go extensively into assorted varieties thus we are able to give our customers much more for their money. What we list we try to have best obtainable.

Annuals bloom first year from seed and the plant dies after one season.

Biennials bloom second year from seed and plant then dies.

Perennials produce flowers second year from seed and plant lives and blooms for several years.

Tender means a plant that thrives in Summer months, but will not survive the least frost.

Half-Hardy means a plant that will stand a little frost and needs protection in the cold months.

Hardy means a plant that will resist considerable frost.

\section{AGERATUM. Floss Flower}

A dwarf, compact-growing, hardy annual, especially valuable for beds and borders. Its bright flowers appear in the greatest profusion throughout the season. Sow the seed early in Spring either in boxes to transplant or out of doors and thin to 4 or 6 inches.

Imperial Dwarf Blue. Pkt. 10ф, 5 pkts. $40 \notin$.

Best Mixed Varieties. Pkt. $5 \varnothing, 5$ pkts. $20 \varnothing$.

\section{ALYSSUM. Sweet}

A pretty, little, hardy annual, universally admired. Splendidly adapted for beds, edgings and rockwork. Small spikes of fragrant, white flowers are produced freely all Summer. Successive crops of fresh blossoms may be obtained by frequent cutting. Seeds should be sown early in Spring.

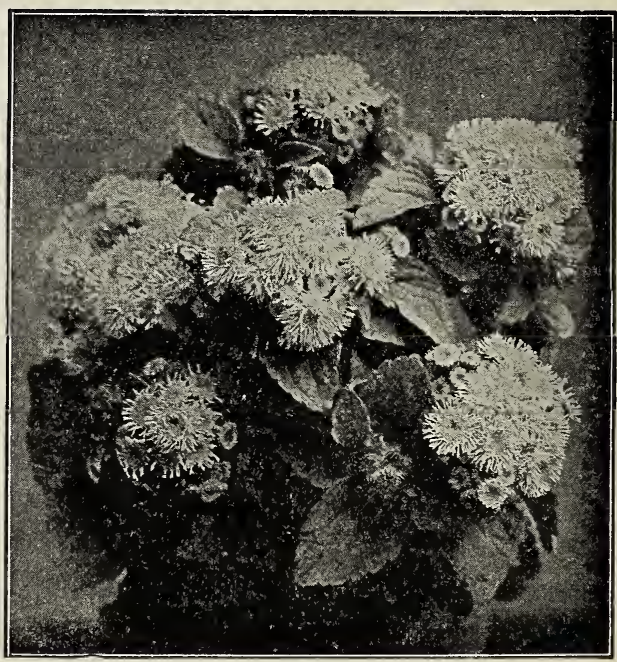

Ageratum

Little Gem. Grows 3 to 4 inches high. Most useful for low beds or edgings, being completely covered with small, white flowers from Spring until frost. Pkt. 5ф, 5 pkts. 20 \&.

White Carpet. A dwarf variety, its masses of flowers producing a perfect carpet of snowy whiteness throughout the Summer. Pkt. $5 \phi, 5$ pkts. $20 \phi$.

AQUILEGIA (See Columbine) 


\section{ANTIRRHINUM. Snapdragon}

This plant is generally known as Snapdragon and is a popular favorite. A half-hardy perennial. growing from 6 inches to 2 feet in height and yielding strikingly graceful spikes of beautiful, oddlyshaped flowers, which are exceptionally desirable for vases and general decorative purposes.

Extra Choice Mixed. Pkt. $10 c, 5$ pkts. 40 ć.

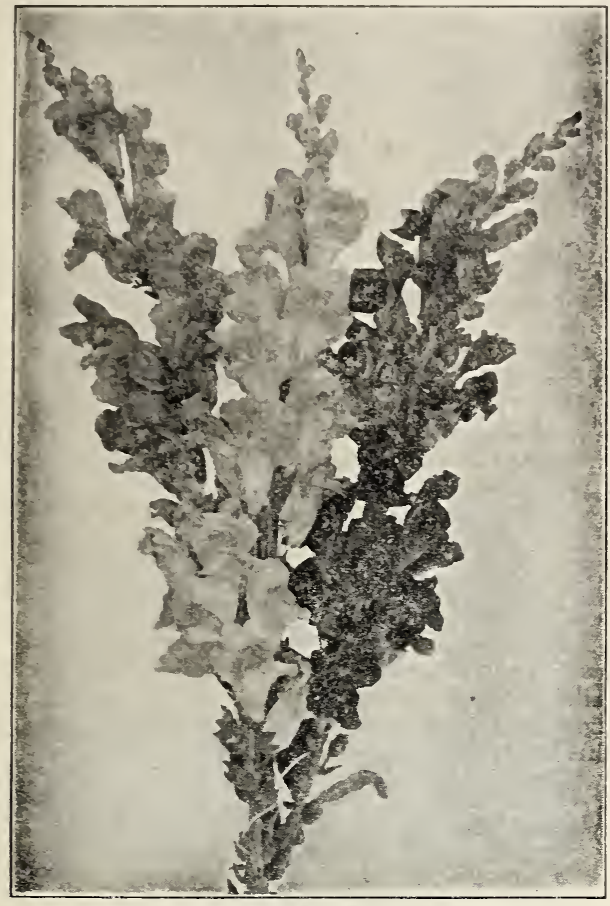

Antirrhinum

ASTERS

The Aster ranks as one of the most important and popular of Summer and Autumn-flowering plants. It is a half-hardy annual, grows from 1 to 2 feet high, is easy to cultivate and produces flowers in a variety of charming colors. For September and October blooming, seed should be sown in May. For early flowering, sow in March or April in hotbed or coldframe, transplanting the seedlings to their permanent quarters when 2 or 3 inches high.

American Branching. The plant is strong and of branching habit and the large, graceful flowers are borne on long stems. Choice mixed pkt. 15 c. 5 pkts. 60 ć.

Queen of Spring (White). Beautiful, white flowers of perfect form. Pkt. $15 c, 5$ pkts. 60 c.

Queen of the Market. An early-flowering variety of branching habit. The good-sized flowers, borne.on long stems, are very valuable for cutting. Choice Mixed. Pkt. 15c, 5 pkts. 60 c.

Choice Tall Mixed. Best varieties. Pkt. 15c. 5 pkts. 60 ć.

Comet. The Comets constitute a really handsome section of the Aster family. They make a grand show in the garden and are of even more value for cut flowers, with their long, wavy, twisted petals, gracefully formed into half globes, resembling Japanese Chrysanthemums. Height, 12 to 15 inches. Choice Mixed. Pkt. 15 c. 5 pkts. 60 c.
Truffaut's Peony-flowered Perfection. A magnificent class, growing from 18 inches to $21 / 2$ feet high, and producing on long stems immense, globe-shaped flowers, with petals incurved like those of the Peony. Mixed. Pkt. 15k. 5 pkts. 60 k. Dwarf Chrysanthemum-flowered. Grows 10 to 12 inches high, bearing large and exceedingly beautiful Chrysanthemum-like flowers.

Mixed. Pkt. $15 \dot{c}, 5$ pkts. 60 c.

BACHELOR'S BUTTON

(Centaurea or Cornflower)

A hardy annual, easily grown. Always admired by flower lovers and to be found in most oldfashioned gardens. Sow the seed early in Spring where it is to flower, and thin to 3 or 4 inches. Finest Mixed. Pkt. $10 \xi, 5$ pkts. 40 .

\section{BALSAM. Lady Slipper}

The Balsam is a tender annual growing 18 inches to 2 feet high. It is easy to cultivate and when grown in fairly rich soil will bear masses of beautiful flowers in great profusion.

Best Double Mixed. Pkt. 5c, 5 pkts. 20 c.

Bellis Perennis. (See Daisy)

\section{CALENDULA \\ (Pot Marigold.)}

Extra hardy annual. One foot.

A splendid annual for all purposes, flowering freely throughout Summer and Fall. The large bright yellow and orange colored flowers are always attractive and last well when cut.

Sow thinly in any good garden soil and thin out or transplant to one toot apart. For early blooming start the seed indoors, and transplant in garden when weather is suitable.

Finest Double Mixed. Pkt. 5 c, 5 pkts. 20 c.

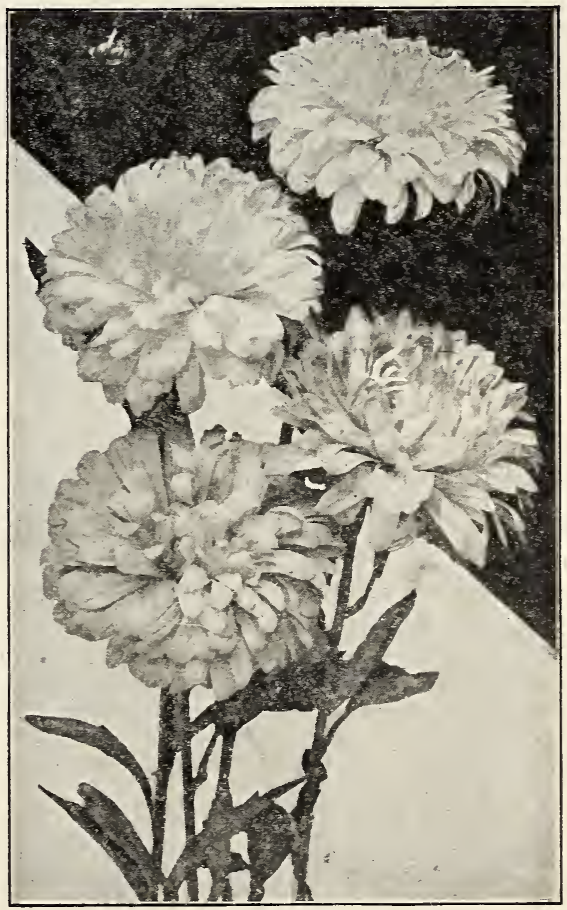

Queen of the Market Aster 


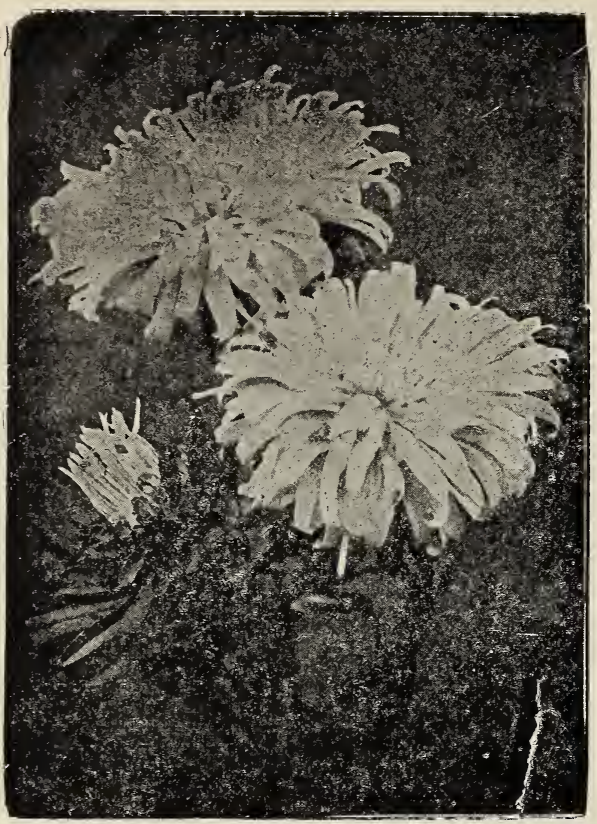

Comet Aster

\section{CALLIOPSIS}

One of the showiest of garden annuals and of easy culture. It blooms all Summer, and the flowers, ranging in color through yellow, golden and crimson, are excellent for cutting. Sow in the open ground in Spring, and give the plants plenty of space to spread.

Finest Mixed. Pkt. $10 \notin, 5$ pkts. $40 \notin$.

\section{CANDYTUFT. Iberis}

This hardy annual is grown almost everywhere and is valued for its extremely pretty flowers, which are very freely produced. It is recommended for bedding or edging and is also deemed indispensable for cutting. Of easy culture and grows 10 to 12 inches high.

Giant Hyacinth-flowered. White. Pkt. $5 \&$. 10 pkts. $40 \notin$.

\section{CALIFORNIA POPPY}

(See Eschscholtzia)

\section{CARNATIONS}

No flower garden is complete without a generous planting of Carnations, which never fail to make a splendid display of blooms and surpassing richness and variety of coloring. The seed should be sown in a hotbed early in the year and transplanted.

Marguerite Carnations. These flower profusely during Summer and Fall from seeds sown in the Spring. They bear an abundance of beautiful flowers of various colors and make a brilliant show in the open garden.

Choice Mixed. Pkt. $15 \AA, 5$ pkts. $60 \AA$.

\section{CANTERBURY BELLS}

A hardy biennial, blooming the second year from seed or first year if sown early. Bell shaped flowers. White, purple and red colors.

Choice Single Mixed. Pkt.10\&, 5 pkts. 40 \&.

\section{CASTOR OIL PLANT (See Ricinus) CENTAUREA (See Bachelor's Button)}

\section{COLUMBINE (Aquilegia)}

A beautiful hardy perennial about 2 feet high and will do well in partial shady places, blooms in late spring and early summer. The flowers are brilliant and in various colors and very attractive. Sow in boxes or beds in Spring or Summer and transplant in good soil one foot apart.

Finest Double Mixed. Pkt. $10 \phi, 5$ pkts. $40 \phi$.

\section{CONVOLVULUS (See Morning Glory) COSMOS}

For cutting purposes the Cosmos is one of the finest flowers grown. It is a favorite Autumn, blooming plant and a prolific bearer of exquisite blossoms in white, crimson and pink, which with the feathery foliage are splendidly adapted for house decoration when other flowers are not plentiful. Sow the seed in early Spring in open ground, or under glass and afterward transplant. Pinching the plant tops when about 18 inches high induces a bushy growth.

Choice Mixed Varieties. Pkt. $10 \phi, 5$ pkts. $40 \phi$.

\section{DAISY}

\section{(Bellis Perennis)}

An old favorite and charming hardy plant. If sown in early Spring will flower in late Summer and Fall. Seed sown later will bloom in Spring, with slight protection in Winter with straw or leaves. Finest Double Mixed. Pkt. $15 \%, 5$ pkts. $60 \phi$.

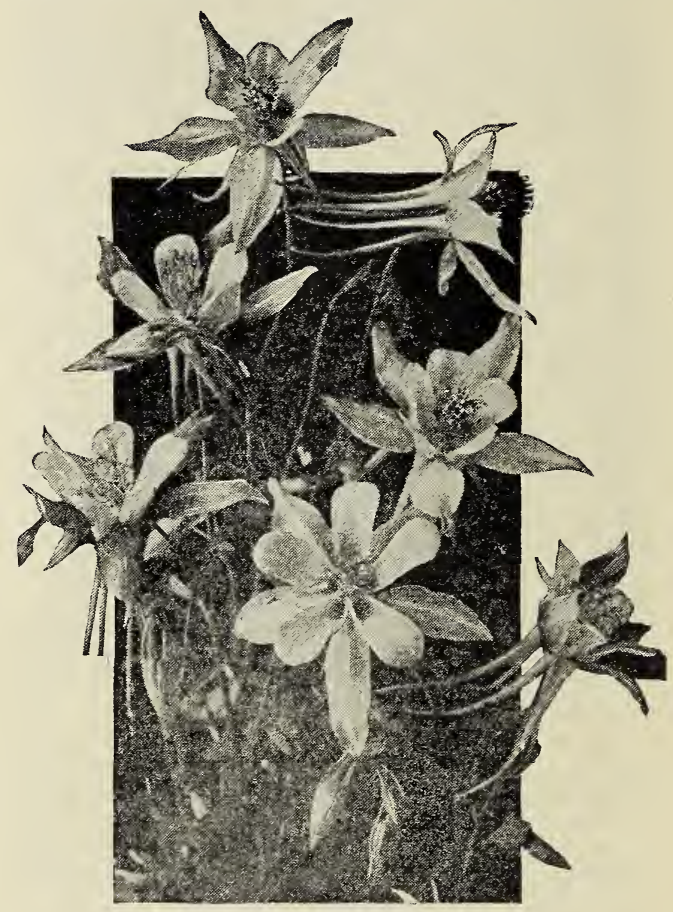

Columbine 


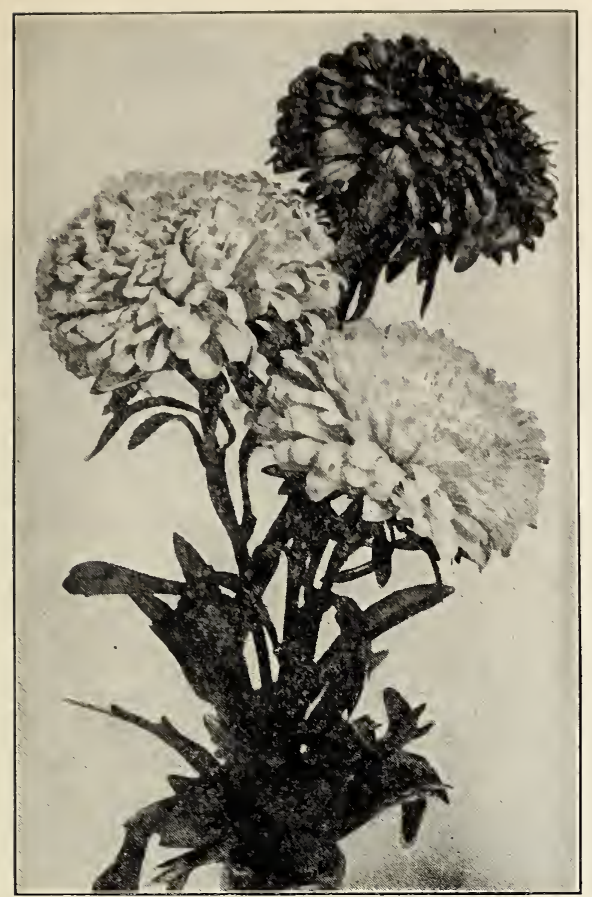

Choice Tall Mixed Aster

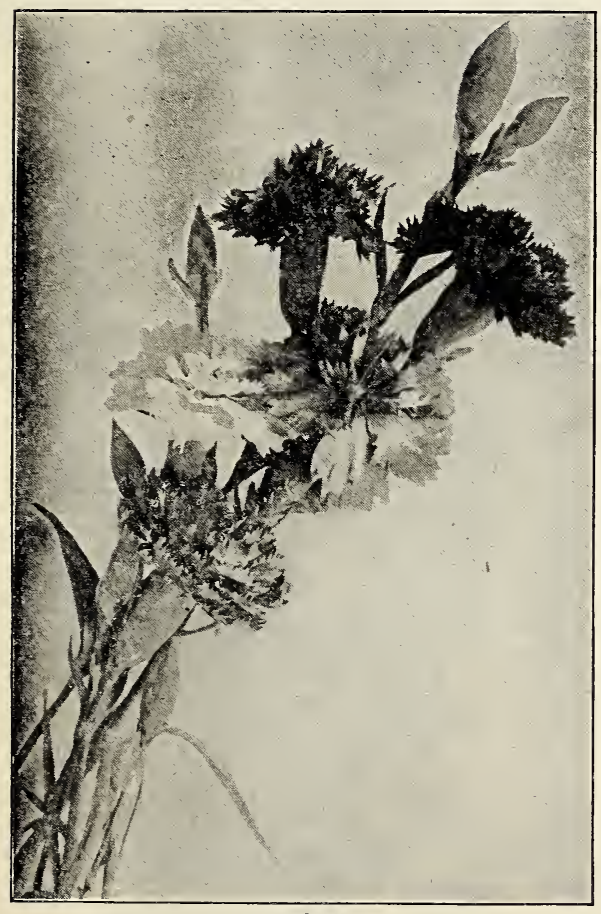

Dianthus

\section{DIANTHUS. Pinks}

The Dianthus, or Pink, is a hardy annual too well known to need much description or commendation.
It is one of the oldest of garden favorites and produces flowers which for brilliancy and diversity of coloring are unrivaled. It thrives best in a sunny location.

Splendid Mixed Varieties. Pkt. 10 \&. 5 pkts. 40 \&.

DIANTHUS BARBATUS

(See Sweet William)

DIGITALIS. Foxglove

Foxgloves succeed in any moderately rich soil, and with their long, stately spikes of bell-shaped

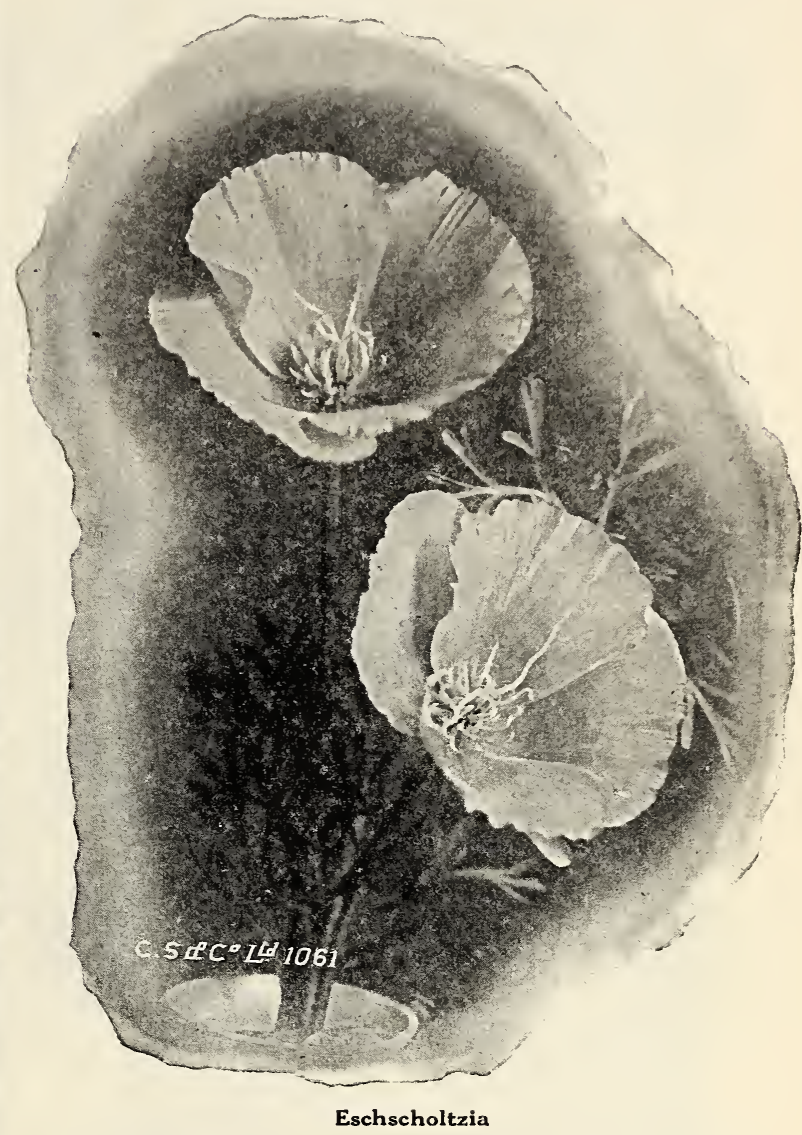

flowers of various hues produce a striking effect wherever planted. They revel in either sunny or partially shaded positions and are at their best during June and July.

Choice Mixed Varieties. Pkt. $5 \phi, 5$ pkts. $20 \phi$.

\section{ESCHSCHOLTZIA}

Hardy annual. Height one foot. (California Poppy) A beautiful free flowering plant, blooming profusely from early Summer until frost. If sown in the fall it will bloom from Spring until Fall. The glacous green finely cut foliage forms a splendid background for the large poppy-like flowers, which range in color from creamy white through shades of yellow and rose to reddish orange.

Sow thinly in early Spring $1 / 4$ inch and thin out to 6 to 8 inches apart. Sow where plants are wanted to bloom, as they do not transplant well.

Finest Mixed. Pkt 5£, 5 pkts. 20 ć. 


\section{FLOSS FLOWER (See Ageratum) FORGET-ME-NOT. Myosotis}

This lovely little favorite will flourish in almost any soil, but prefers a moist, shady location. A free-blooming, hardy perennial which makes an effective flower-bed border.

Finest Mixed. Pkt. $10 \AA, 5$ pkts. 40 ф́.

\section{FOXGLOVE (See Digitalis)}

FOUR O'CLOCKS (See Marvel of Peru)

\section{GAILLARDIA}

A very showy hardy annual garden plant blooming freely in Summer and Autumn. A great border plant, the brilliant, scarlet and yellow flowers, blended and shaded make a great showing and used extensively for cut flowers. Sow early and thin to about 9 inches.

Choice Mixed. Pkt. 10ф, 5 pkts. 40ф.

\section{HELIANTHUS (See Sunflower) \\ HELICHRYSUM \\ (Straw Flower) \\ Hardy annual. Height $21 / 2$ feet.}

The most popular "Everlasting." Succeeding in any good garden soil and producing throughout the late Summer large handsome double flowers in a great variety of colors. Much prized for Winter bouquets. Cut just before the yellow center of the flower is exposed and dry in a cool airy place.

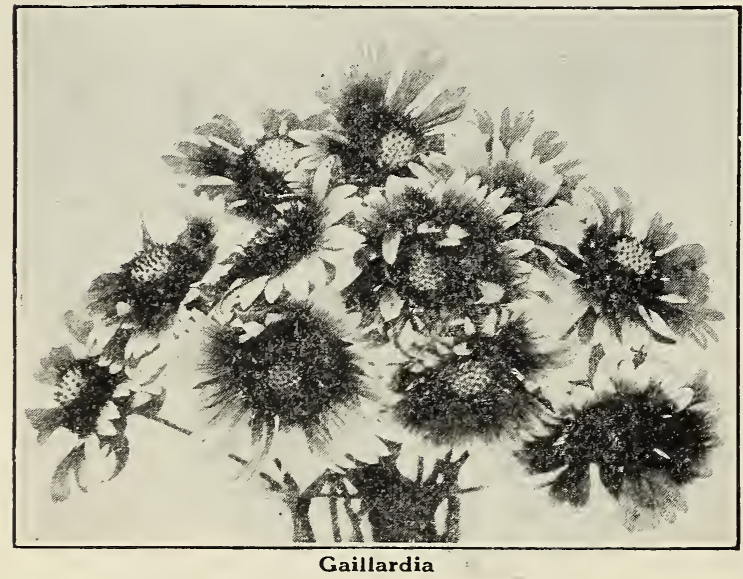

Sow one-eighth inch deep in fine soil under glass in early Spring or later in the open. Thin out or transplant 12 inches apart.

Finest Mixed. Pkt. 10c., 5 pkts. 40c.

\section{HELIOTROPE}

A half-hardy perennial growing about 1 foot high, and held in high favor on account of its delightful fragrance. Grows well in both conservatory and open garden.

Finest Mixed. Pkt. $15 \phi, 5$ pkts. $60 \phi$.

\section{HOLLYHOCK}

One of the oldest inhabitants of the garden. bearing long, majestic spikes of beautiful flowers. Especially effective in masses, among shrubbery, or forming a background for other flowers. A hardy perennial of vigorous growth, reaching a height of 6 to 8 feet. Sow any time in early Spring to Midsummer. Finest Double Mixed. Pkt. $15 \phi, 5$ pkts. 60 \&.

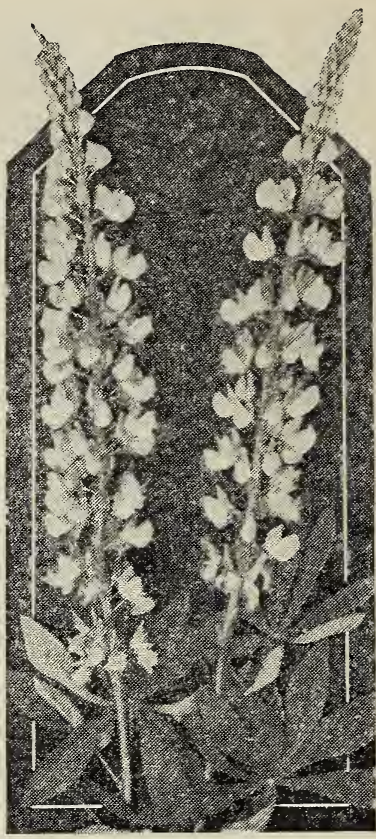

Lupinus

\section{IBERIS (See Candytuft)}

\section{LADY SLIPPER (See Balsam)}

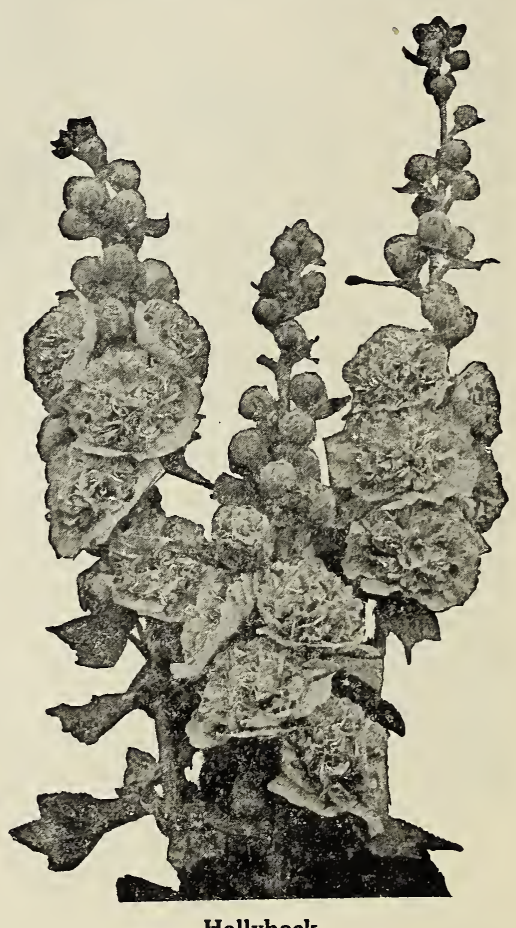

Hollyhock 


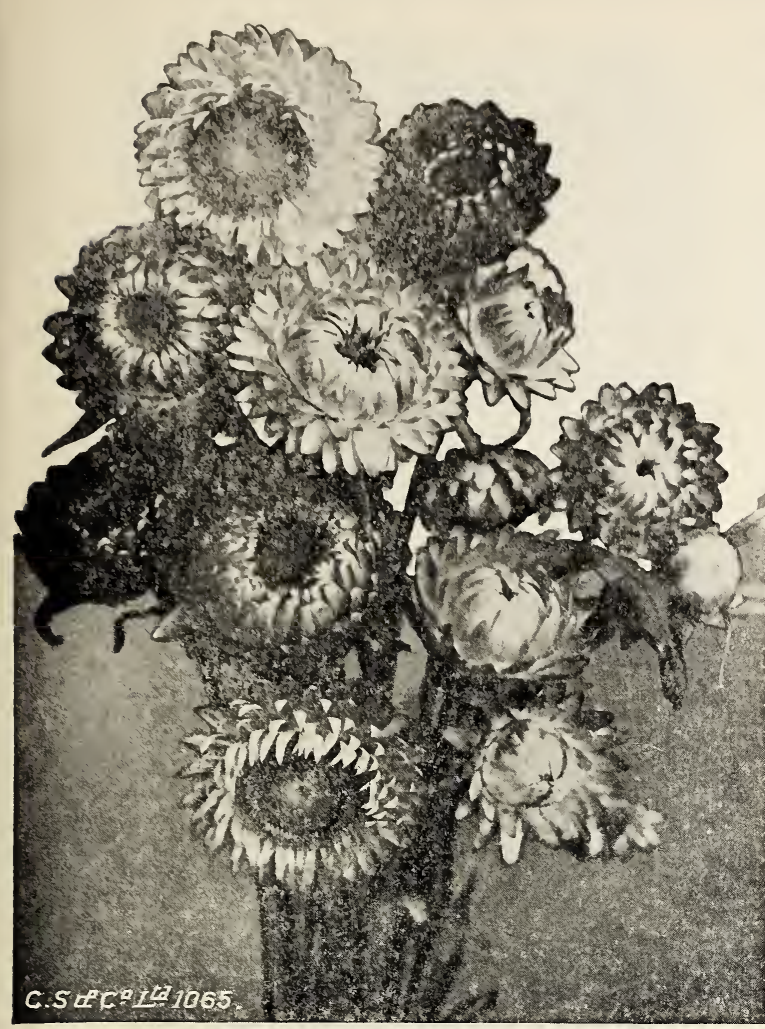

Helichrysum

\section{LARKSPUR \\ (Delphinium)}

There are two kinds of Larkspur. The Annual and the Perennial Larkspur.

Annual Larkspur. A hardy annual plant that grows $11 / 2$ to 2 feet high and produces abundance of flowers in colors and easy to cultivate. Mixed varieties. Pkt. $10 \phi, 5$ pkts. $40 \phi$.

Perennial Larkspur. This variety grows taller than the annual and the flowers and foliage are very attractive. Very often a second crop of flowers will be produced if the plants are kept well watered and the flowers picked.

Choice Mixed. Pkt. $15 \phi, 5$ pkts. $60 \phi$.

\section{LUPINUS}

An excellent hardy perennial border plant. The tall spike flowers are also extensively used as cut flowers and the foliage is very ornamental. Sow in Spring or Summer and thin or transplant to about 18 inches apart.

Finest Mixed. Pkt. $5 \notin, 5$ pkts. $20 \notin$.

\section{MARIGOLDS}

Extremely attractive, free-blooming, hardy annuals, of easy culture, and recommended where a magnificent display is desired during the Summer and Autumn months. The flowers are of various shades of yellow and brown. The tall or African varieties are valuable for large bedding or background work, while the Dwarf or French sorts are most admired when set out in borders.
Eldorado (Tall). Mixed Colors. Pkt. $10 \notin, 5$ pkts. $40 c$.

Dwarf, Gold-Striped. Pkt. $10 \notin .5$ pkts. $40 \notin$.

\section{POT MARIGOLD (See Calendula) MARVEL OF PERU, OR FOUR O'CLOCKS. Mirabilis}

An elegant Summer-blooming, hardy annual growing 12 to 18 inches high and bearing a profusion of brilliant flowers, which appear in the afternoon. Sow seed in the open and thin to $I$ foot. Does well in any soil.

Finest Mixed. Pkt. 5 \&. 5 pkts. 20 c.

\section{MIGNONETTE. Reseda}

Mignonette is a charming and immensely popular hardy annual, producing spikes closely set with flowers of sweet and delicate fragrance. Seeds sown in April and again in July will keep up a succession of flowers through the Summer and Autumn. Grows 6 to 12 inches high, and is very desirable for potting, bedding or bordering.

Large-flowering. Pkt. $10 \AA, 5$ pkts. 40 \&.

Machet. Fine selected stock. Pkt. 10 .

5 pkts. $40 \AA$.

\section{MIRABILIS (See Marvel of Peru)}

\section{MORNING GLORY. Convolvulus}

One of the most beautiful and rapid growing climbers in cultivation, carrying flowers of surpassing beauty and delicacy of coloring. To accelerate germination the seed may be soaked in tepid water for about an hour. There is no difficulty in cultivation, and the vines grow to a length of 10 to 15 feet.

Choice Mixed. Pkt. 5k, 5 pkts. $20 \dot{\phi}$.

\section{MOURNING BRIDE (See Scabiosa) MYOSOTIS (See Forget-Me-Not)}

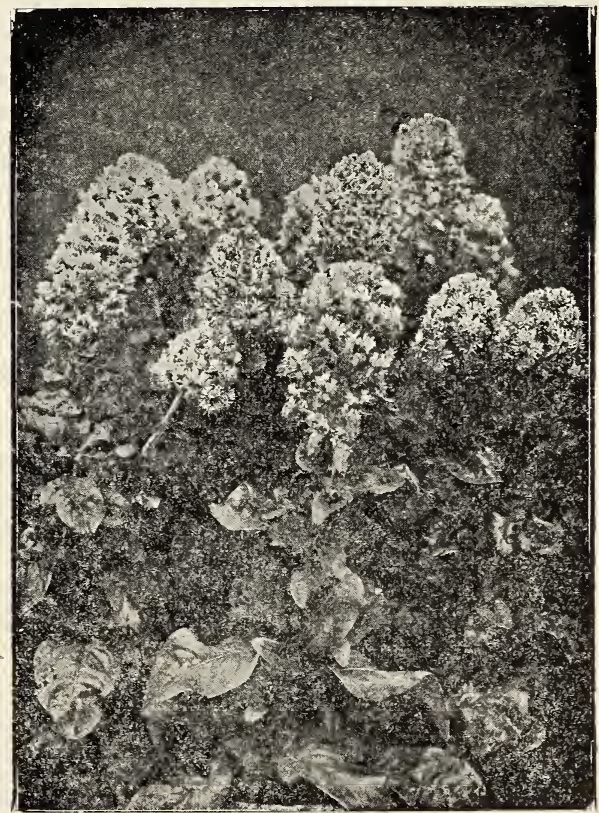

Mignonette 


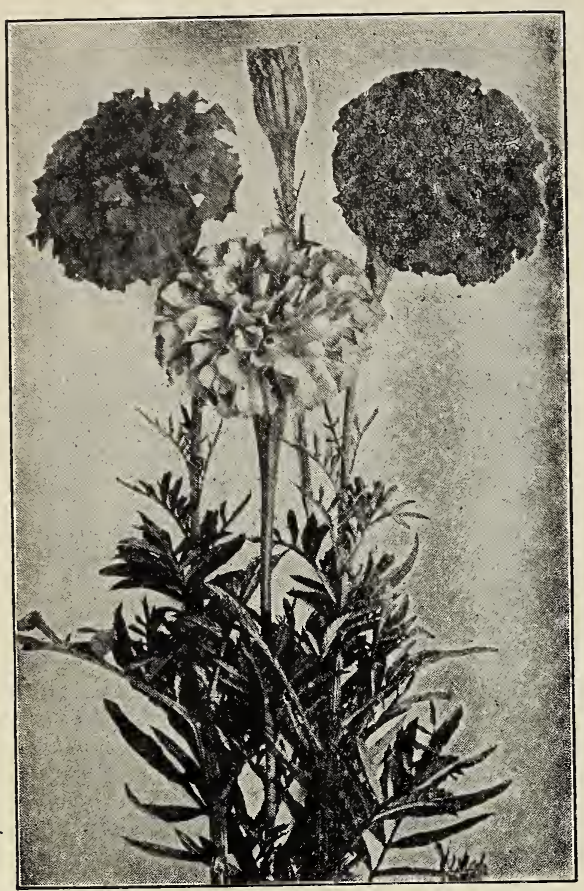

Marigold

\section{NASTURTIUMS}

Free-flowering, tender annuals of general excellence and of easy culture. If planted in fairly rich soil they grow luxuriantly until frost and bear an endless profusion of blooms of the most charming colors. The cut flowers are particularly effective for table decoration. Tall Nasturtiums are especially useful for covering trellises, verandas, rockwork, etc., while the Tom Thumb or dwarf varieties, many with variegated foliage, are extremely effective in flower beds or borders.

Tall. Finest Mixed Colors. Pkt. $5 \phi$, oz. $10 \phi$, $1 / 4$ lb. 35 \&, lb. $\$ 1.00$.

Dwarf. Finest Mixed Colors. Pkt. $5 \phi$, oz. $10 \phi$. $1 / 4$ lb. $35 \phi$, lb. $\$ 1.00$.

\section{PAPAVER (See Poppy)}

\section{PANSY}

The Pansy, a half-hardy perennial, is a general favorite among all flower lovers, and very few gardens are seen without a showing of its exquisite blooms. Best results are obtained in a rich, loamy soil and a partially shaded, cool and moist situation. The plants may be Wintered by giving a protection of leaves or hay. For a continuous supply it is advisable to start a new bed each year.

Trimardeau Mixture. A superior strain of vigorous growth, producing enormous flowers of great beauty. Pkt. $15 \phi, 5$ pkts. $60 \phi$.

Large French Strain Mixture. A unique type, with magnificent flowers, many of them beautifully variegated. Pkt. $15 \phi, 5$ pkts. $60 \phi$.

Superb Mixture (Pansy). An assortment of the best large-flowered varieties, grown separately and carefully blended. Pkt. 15 \&, 5 pkts. $60 \phi$.

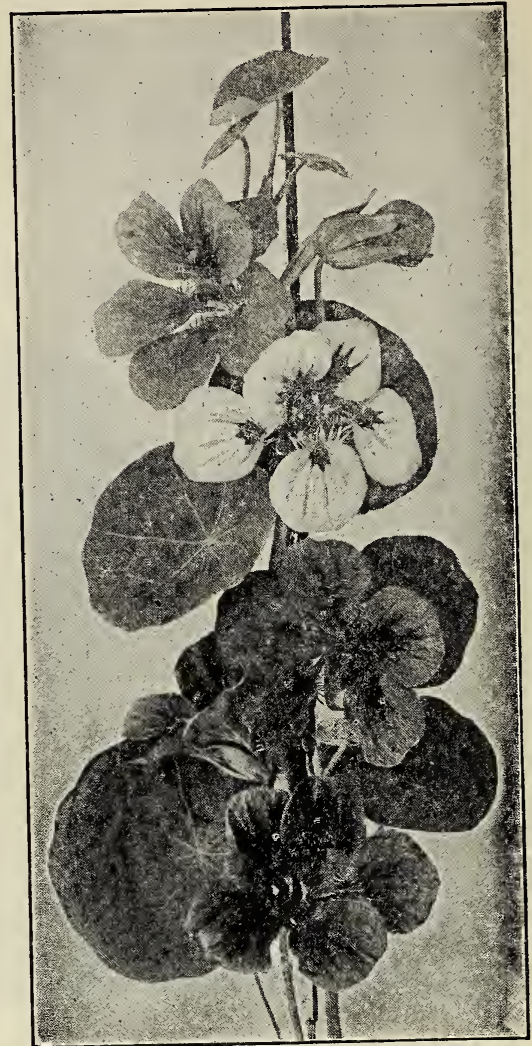

Nasturtiums

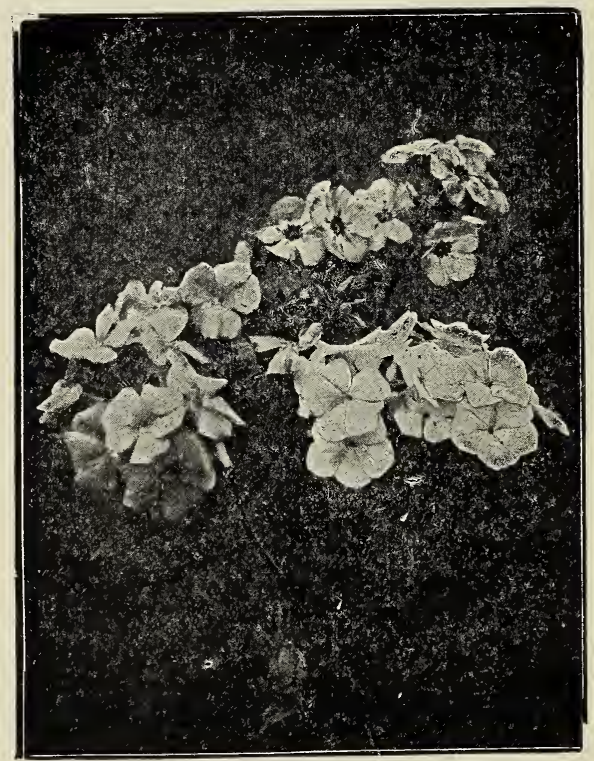

Phlox Drummondii Grandiflora 


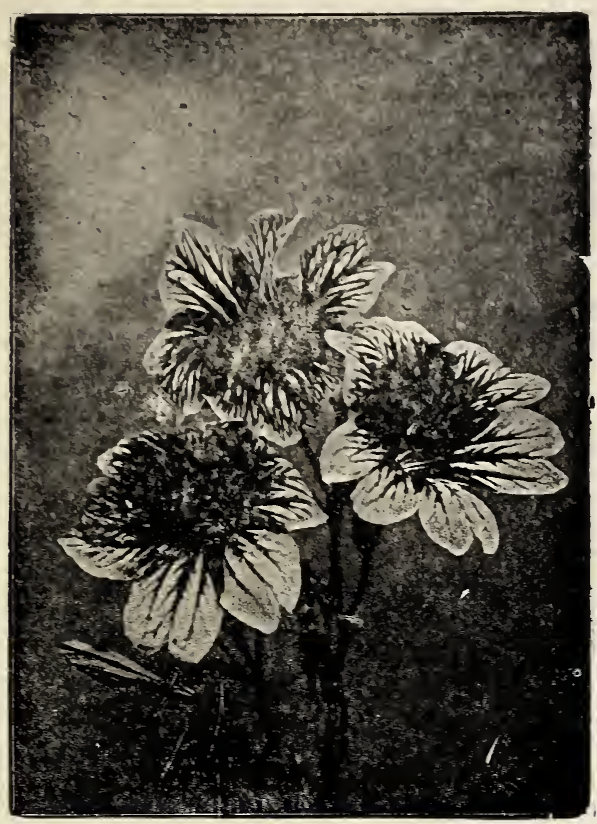

Salpiglossis

\section{PETUNIA}

The numerous varieties of Petunias produce, in great quantity, flowers of surpassing beauty, and are valued for use in beds, borders, massing, windowboxes, vases and baskets. Easily cultivated in good soil and a sunny position and display a mass of bloom throughout the season. Sow in box or flower pot and transplant later.

Extra Choice Single Mixed. Pkt. 15 k, 5 pkts. $60 \notin$.

\section{PHLOX. Drummondii Grandiflora}

A beautiful hardy annual, which for beds and massing purposes is unexcelled. It certainly merits a place in every garden. Enormous trusses of flowers are produced in wide range of colors. Sow seed in early Spring, and thin sufficiently to avoid overcrowding.

Choice Mixed. Pkt. $10 k$, 5 pkts. $40 \dot{k}$.

\section{POPPY. Papaver}

For beauty, delicacy and variety of coloring, this exceedingly popular hardy annual is unbeatable. Both single and double varieties make gorgeous shows during their flowering period, and are invaluable for beds and borders. Sow seed in open ground where plants are to remain and thin to 6 to 10 inches.

The Shirley. Mixed. Large, single flower. Pkt. $5 \dot{k}, 5$ pkts. $20 \dot{\phi}$.

\section{RESEDA. (See Mignonette)}

\section{RICINUS. Castor Oil Plant}

A tender annual of luxuriant and quick growth, attaining a height of 6 to 10 feet. With its picturesque, palm-like foliage, it produces a distinctly sub-tropical effect. Much used for lawns and centers of foliage beds. Pkt. 5 \&, 5 pkts. 20 .

\section{SALPIGLOSSIS}

This is one of the most beautiful and highly prized half-hardy annuals. It is easily grown and bears pretty, funnel-shaped flowers in many rich shades of color from early Summer until late Autumn. Revels in a light, rich soil. Sow seed early and transplant or thin to 6 to 8 inches.

Choice Mixed. Pkt. $10 \notin, 5$ pkts. 40 .

\section{SALVIA. Scarlet Sage}

An elegant Summer and Fall-flowering bedding plant, with long spikes of brilliant scarlet; blooms from July until frost. Seed should be started early indoors and the young plants transferred to the open ground after all danger of frost is over. Seed hard to germinate. Sow thickly.

Splendens. Bright scarlet. Pkt. 15 k, 5 pkts. 60 k.

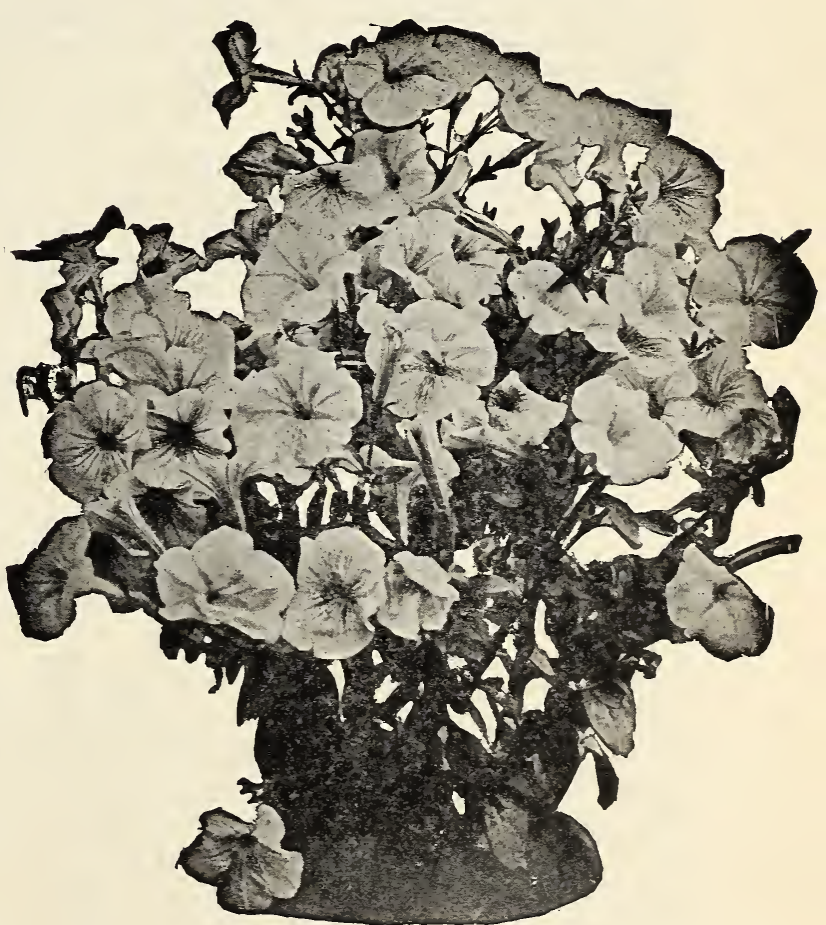

Petunia 


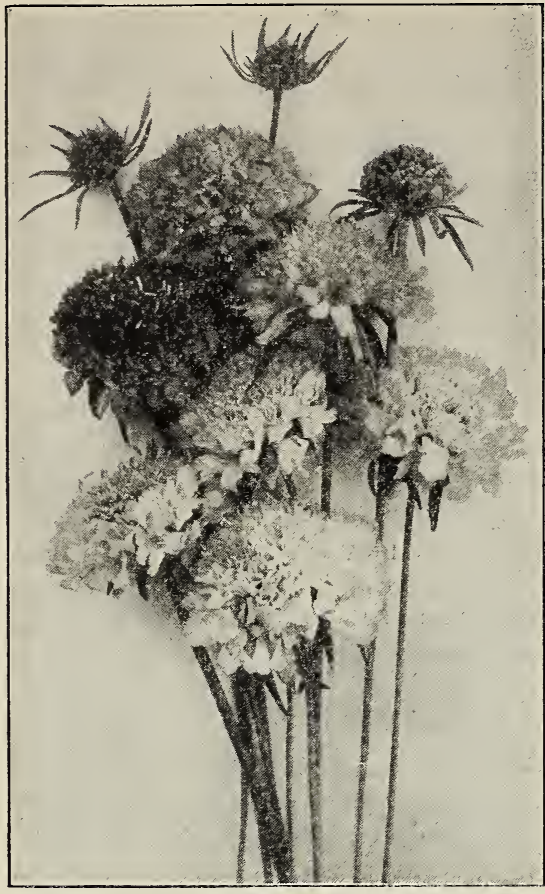

Scabiosa

\section{SCABIOSA. Sweet Scabious Mourning Bride}

A handsome border plant, and no garden is complete without it. Attaining a height of $2 \frac{1}{2}$ feet, it commences to bloom the latter part of June and continues to bear exquisite flowers on long stems until frost.

Tall Mixed German Double. Pkt. $5 \phi, 5$ pkts. 20 \&.

\section{SCARLET SAGE (See Salvia) \\ SUNFLOWER. Helianthus}

This well-known hardy annual grows 6 to 8 feet high and produces immense yellow flowers which are very effective. The flower seeds are considered excellent food for poultry.

Mammoth Russian. Oz. 5 \&, 1/4 lb. 15 \&, lb. 25 \&.

\section{SWEET PEAS}

This is a very popular flower and you might say in a class by itself. It is a hardy annual climber and easy to cultivate and when grown under favorable conditions will produce abundance of bright and very fragrant flowers in various colors. As the vines grow 3 to 6 feet high they need some kind of support, brush and wire are generally used. Sometimes they are grown beside fences and buildings which support them.

The seed should be sown as early in the Spring as the soil can be worked, forcing the young plants as much as possible to get ahead of the hot weather. Sow in drills 5 or 6 inches deep and cover the seed about an inch, working the soil up to the plants as they grow until even with the surface. See that they have plenty of water and cultivate frequently.

The Grandiflora or common types are practically gone out of date and we only list them in a mixture.

The Spencer and Wavy types we list a few of the leading varieties in assorted colors as well as in a mixture.
Aurora Spencer. A brilliant orange rose striped and flaked on white. One of the finest and largest of the Spencer sorts. Oz. $25 \phi, 1 / 4$ lb. $65 \phi, \mathrm{lb} . \$ 2.50$.

Austin Frederick Improved. Finest pure lavender. Probably the best lavender colored Sweet Pea in existence. Oz. $30 \notin, 1 / 4$ lb. $85 \notin, \mathrm{lb} . \$ 3.00$.

Campfire. The bright, scarlet, sunproof Sweet Pea, very vivid color and the flowers will stand the hottest sunshine. Large size and form in great quantities. Oz. $40 \phi, 1 / 4$ lb. $\$ 1.40$, lb. $\$ 5.00$.

Crimson King. A large crimson red variety producing abundance of long stemmed flowers. Oz. 30 \&, $1 / 4$ lb. 85 \&, lb. $\$ 3.00$.

Dora. Rosy pink standard with cream colored wings. One of the best bicolored varieties. $\mathrm{Oz}$. $25 \phi, 1 / 4$ lb. 65 \&, lb. $\$ 2.50$.

Doreen. The largest and brightest of the carmine colored. The plants are vigorous and bears a profusion of four blossom sprays. Oz. $40 \AA, 1 / 4 \mathrm{lb}$. $\$ 1.40$, lb. $\$ 5.00$.

Hawlmark Pink. Deep rich pink tinted with orange and salmon. The large flowers grow on vigorous plants. $\mathrm{Oz} .30 \%, 1 / 4 \mathrm{lb} .85 \phi, \mathrm{lb} . \$ 3.00$.

Miss California. An orange salmon cream pink colored novelty of exceptional merit that attracts the attention of both the expert and the novice. Oz. $40 \&, 1 / 4 \mathrm{lb} . \$ 1.40$, lb. $\$ 5.00$.

Majestic. A very large deep cream colored variety bearing flowers in great profusion. Oz. $25 \phi, 1 / 4$ lb. 65 \&, lb. $\$ 2.50$.

Picture. A fine creamy pink flower, well frilled and wavy. A splendid variety. Oz. $30 \notin, 1 / 4 \mathrm{lb}$. 85 c, lb. $\$ 3.00$.

Rosabelle. A bright rose crimson variety quite popular with many. Oz. $25 \&, 1 / 4$ lb. $65 \&, \mathrm{lb}$. $\$ 2.50$.

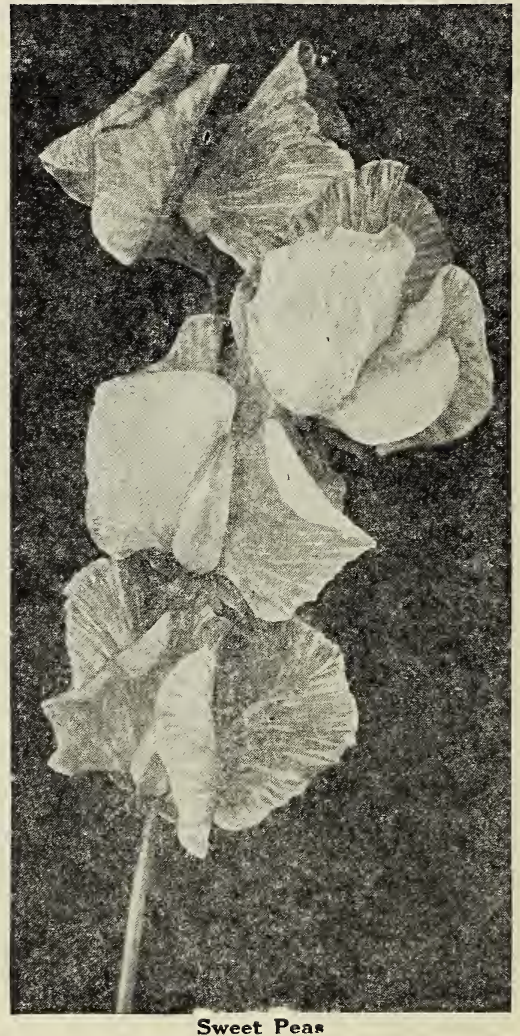


Splendour. The giant flowers of mahogany maroon are generally borne in fours on long stems. Oz. 25 c, 1/4 lb. 65 c, lb. $\$ 2.50$.

White Spencer. Pure white, large wavy flowers with long strong stems. Oz. 30 c, $1 / 4$ lb. 85 c. lb. $\$ 3.00$.

Youth. A large and fragrant variety, white edged in beautiful manner with delicate soft rose pink. Oz. 40 ć, $1 / 4$ lb. $\$ 1.40$, lb. $\$ 5.00$.

Choice Spencer Mixture. Oz. 20 k, 1/4 lb. 60 , lb. $\$ 2.00$.

Finest Mixed. (Grandiflora or Common Type.) Oz. 10 c, $1 / 4$ lb. 25 c, lb. 75 c.

SWEET WILLIAM. Dianthus Barbatus Long regarded as one of the finest of hardy perennials, the popular Sweet William is most effective when used.in the old-fashioned bed or border; it is also very desirable for cutting. The plant is easily grown and a plentiful supply of rich and varied blooms come the second year from seed.

Double Finest Mixed. Pkt. $10 \hat{c}, 5$ pkts. $40 \hat{c}$.

\section{VERBENA}

A half-hardy trailing perennial of easy culture. Strongly recommended for beds, borders, vases or window-boxes, on account of its neat foliage and great profusion of flowers.

Henderson's Mammoth. Finest Mixed. Pkt. $10 \hat{c}, 5$ pkts. $40 \hat{c}$.

\section{ZINNIA. Youth and Old Age}

The Zinnia is one of the most satisfactory and attractive hardy annuals and occupies a prominent place in many flower gardens. The plants are easily grown from seed and to admit of proper development they should be transplanted 8 to 10 inches a part. They come into flower early and continue making a grand display of gorgeous blooms in beds and borders until smitten by hard frost.
Double Fine Mixed. Pkt. $5 \xi, 5$ pkts. $20 k$.

Giant Double Mixed. Pkt. $10 \hat{\text { c., }} 5$ pkts 40 ć.

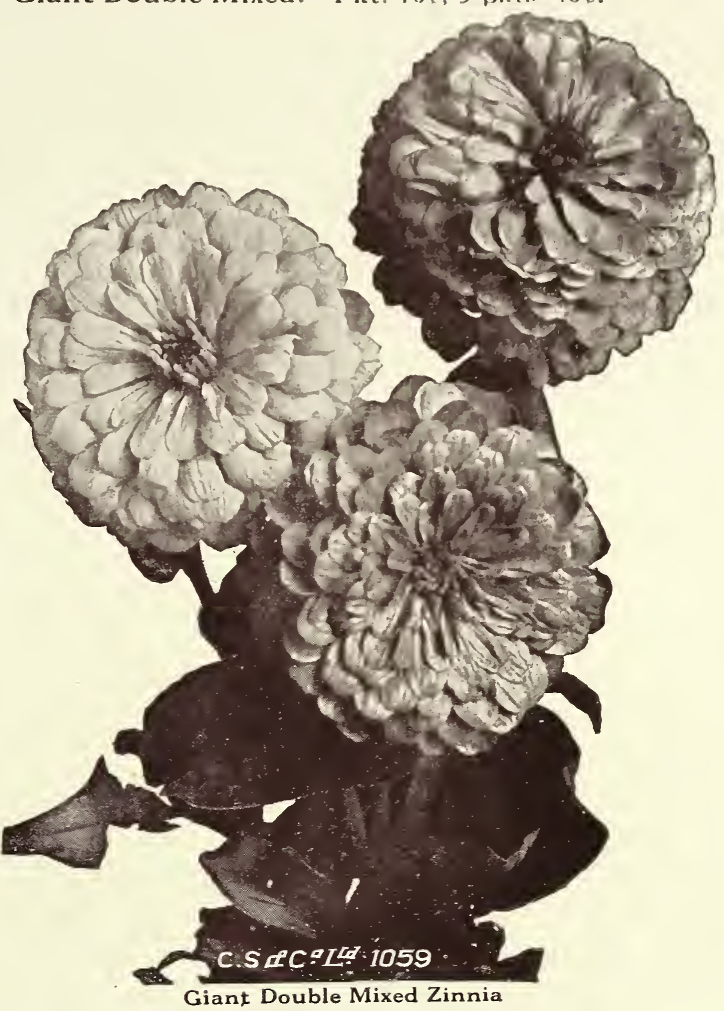

\section{INDEX}

\begin{tabular}{|c|c|c|}
\hline Vegetable Seeds & $\begin{array}{r}\text { Page } \\
29,30\end{array}$ & \\
\hline Asparagus, Seed.............. & 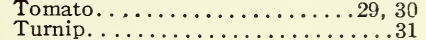 & $\begin{array}{l}\text { Columbine } \ldots \ldots \ldots \ldots \ldots \ldots \ldots \ldots \\
\text { Convolvulus.............. }\end{array}$ \\
\hline Beans, Dwarf, Green-Podded........ 2 & 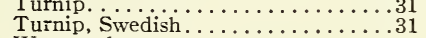 & Cosmos..................... \\
\hline “Wax, or Butter........ 3 & Watermelons...................... & Diasy.... \\
\hline $\begin{array}{l}\text { Dwarf, or Bush Lima...... } 3 \\
\text { Pole, or Running........... } 4\end{array}$ & Grass and Farm Seeds & Dianthus \\
\hline "eets, Gole, or Running. . . . . . . . . 4 & 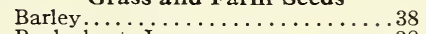 & Barbatus........... \\
\hline$"$ Mangel................ 5 & Buckwheat, Japanese.......... 38 & 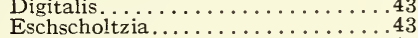 \\
\hline “ Spinach $\ldots \ldots \ldots \ldots \ldots \ldots 7,8$ & Clover............. 32,33 & 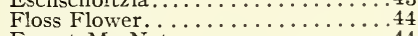 \\
\hline $\begin{array}{l}\text { Borecole or Kale } \ldots \ldots \ldots \ldots \ldots \ldots \ldots \ldots 17 \\
\text { Brussels Sprouts. . } \ldots \ldots \ldots \ldots \ldots \ldots 66\end{array}$ & Corn Ensilage $\ldots \ldots \ldots \ldots \ldots 35,36,37$ & 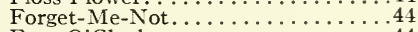 \\
\hline 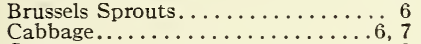 & Fescueld...............35, 36, 37 & 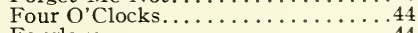 \\
\hline $\begin{array}{l}\text { Cabbage } \ldots \ldots \ldots \ldots \ldots \ldots \ldots \ldots \ldots{ }^{6}{ }^{7} \\
\text { Carrots...... }\end{array}$ & 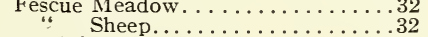 & Foxglove. . . . . . . \\
\hline 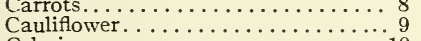 & Herd Grass..................... & 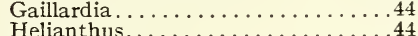 \\
\hline Celeriac...................... & Kentucky Blue Grass.......... & 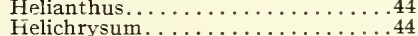 \\
\hline 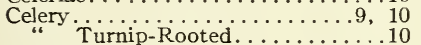 & Lawn Grass. . . . . . . . . . . . . . & $\begin{array}{l}\text { Helichrysum. . . . . . . . . . . . . . } \\
\text { Heliotrope. }\end{array}$ \\
\hline 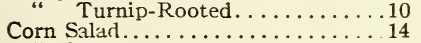 & 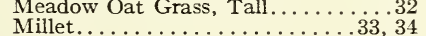 & Hollyhock. . . . . . . . . . \\
\hline Corn Salad.............. ${ }_{\text {Sweet..... }}$ & Oats.............................. & Iberis ...... \\
\hline Cress................... 16 & Orchard Grass............. 32 & $\begin{array}{l}\ldots \ldots \ldots \ldots \ldots \\
\ldots \ldots \ldots \ldots \ldots \ldots\end{array}$ \\
\hline 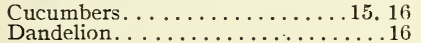 & 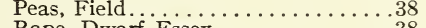 & $\ldots \ldots \ldots \ldots \ldots \ldots$ \\
\hline $\begin{array}{l}\text { andelion } \ldots \ldots \ldots \ldots \ldots \ldots \ldots \ldots \ldots \\
\text { gg Plant. } \ldots \ldots \ldots \ldots \ldots \ldots \ldots \ldots \ldots \\
16\end{array}$ & 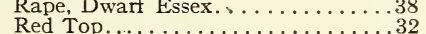 & 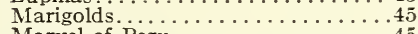 \\
\hline $\begin{array}{l}\ldots \ldots \ldots \ldots \ldots \ldots \ldots{ }^{16} \\
\ldots \ldots \ldots \ldots \ldots \ldots \ldots 16\end{array}$ & Rye and Vetch Mixture.......... & Marvel of Peru. ............. \\
\hline 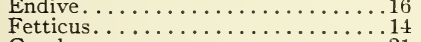 & Rye, IVinter. . . . . . . . . . . . & Mignonette. . . . . . . . . . \\
\hline$u m b o \ldots \ldots \ldots \ldots \ldots \ldots \ldots \ldots$ & Rye Grass, Perennial.... . . . . . . 32 & 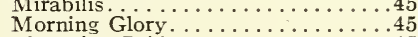 \\
\hline Cale. . . . . . & oy Beans..................... 37 & 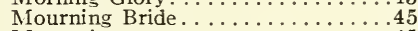 \\
\hline -Rabi $\cdots \cdots \cdots \cdots \cdots \cdots \cdots \cdots$ & 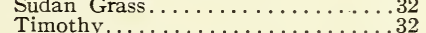 & 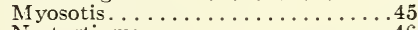 \\
\hline 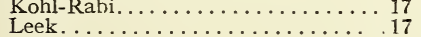 & 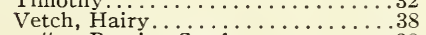 & Nasturtiums. . . . . . . . . . \\
\hline Lettuce......................... & "Russian Sand. . & $\cdots \cdots \cdots \cdots \cdots \cdots \cdots$ \\
\hline 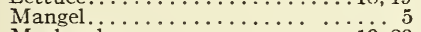 & “ Spring. . . . . . . . . . . 38 & $\ldots \ldots \ldots \ldots \ldots \ldots$ \\
\hline Muskmelon. . . ...........1 & Flower Seeds & Phlox Drummondi Grandiflora... \\
\hline 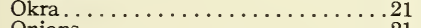 & Ageratum... & 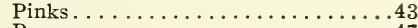 \\
\hline$\ldots \ldots \ldots$ & Alyssum, Sweet. & Poppy... \\
\hline nion Sets............. & Aquilegia .... & 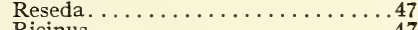 \\
\hline 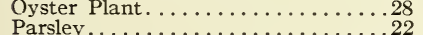 & ntirrhinum........... & $\ldots \ldots \ldots \ldots \ldots$ \\
\hline$\ldots \ldots \ldots \ldots$ & sters. $\ldots \ldots \ldots \ldots \ldots \ldots$ & $\ldots \ldots \ldots \ldots \ldots \ldots$ \\
\hline 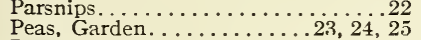 & Bachelor's Button. . . . . . . . . & \\
\hline $\begin{array}{l}\text { Peas, Garden } \ldots \ldots \ldots \ldots \ldots \ldots 23,24,25 \\
\text { Peppers } \ldots \ldots \ldots \ldots \ldots \ldots \ldots \ldots \ldots 22\end{array}$ & 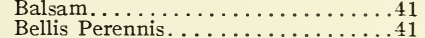 & $\begin{array}{l}\text { losa...... } \\
\text { et Sage. }\end{array}$ \\
\hline Pumpkin.... & 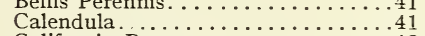 & $\begin{array}{l}\text { let Sage } \ldots \ldots \ldots \ldots \ldots \ldots \ldots \ldots \\
\text { pdragon } . . \ldots \ldots \ldots \ldots \ldots\end{array}$ \\
\hline ish..... & California Poppy.......... & hower.................... \\
\hline barb.... & Calliopsis . . . . . . . . . . . & et Peas.............. \\
\hline$\ldots \ldots \ldots \ldots$ & & t Scabious.............. \\
\hline & terbury Bells....... & eet William.............. \\
\hline $\begin{array}{l}\text { pinach...... } \\
\text { quash..... }\end{array}$ & lations ...... & 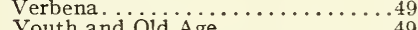 \\
\hline 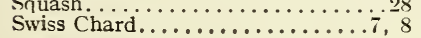 & $\begin{array}{l}\text { Castor Oil Plant....... } \\
\text { Centaurea. }\end{array}$ & th and Old Age..... \\
\hline & & \\
\hline
\end{tabular}


